Aus der Abteilung Neuro- und Sinnesphysiologie

(Prof. Dr. med. D. W. Richter)

im Zentrum Physiologie und Pathophysiologie

der Medizinischen Fakultät der Universität Göttingen

\title{
Charakterisierung von Astrozyten im respiratorischen Netzwerk
}

\author{
INAUGURAL-DISSERTATION \\ zur Erlangung des Doktorgrades \\ der Medizinischen Fakultät \\ der Georg-August-Universität zu Göttingen
}

vorgelegt von

Dennis Graß

aus

Paderborn

Göttingen 2005 
Dekan: Prof. Dr. med. C. Frömmel

I. Berichterstatter: PD Dr. med. S. Hülsmann

II. Berichterstatter/in: Prof. Dr. rer. nat. K. Krieglstein

III. Berichterstatter/in:

Tag der mündlichen Prüfung: 13. Juli 2006 
2.4. Nachweis von mRNA durch Einzelzell-Reverse-Transkriptase-PolymeraseKettenreaktion (Einzellzell-RT-PCR)

3.3. Korrelation zwischen EGFP-Fluoreszenzintensität und elektrophysiologischen Eigenschaften

3.5. Expression von neuronalen und glialen Proteinen in verschiedenen Astrozyten-Typen 46 
4.1. Unterschiedliche Eigenschaften von Astrozyten im respiratorischen Netzwerk

4.2. Stabilisierung der synaptischen Funktion durch Astrozyten mit passiven $\mathrm{K}^{+}$-

Leitfähigkeiten und Glutamat-Transportern

4.3. Stellen auswärts gleichrichtende Astrozyten eine eigene Zellpopulation dar? 


\section{Einleitung}

\subsection{Das respiratorische Netzwerk}

\subsubsection{Anatomie des respiratorischen Netzwerkes}

$\mathrm{Zu}$ den lebenswichtigen physiologischen Systemen eines jeden Tieres zählt die Atmung. Vom Moment der Geburt an müssen lebenslang und andauernd alle Teilbereiche dieses Systems zuverlässig arbeiten. Dazu zählt neben der zellulären Atmung, dem Gasaustausch und der Motorik, die die Ventilation ermöglicht, auch die neuronale Kontrolle.

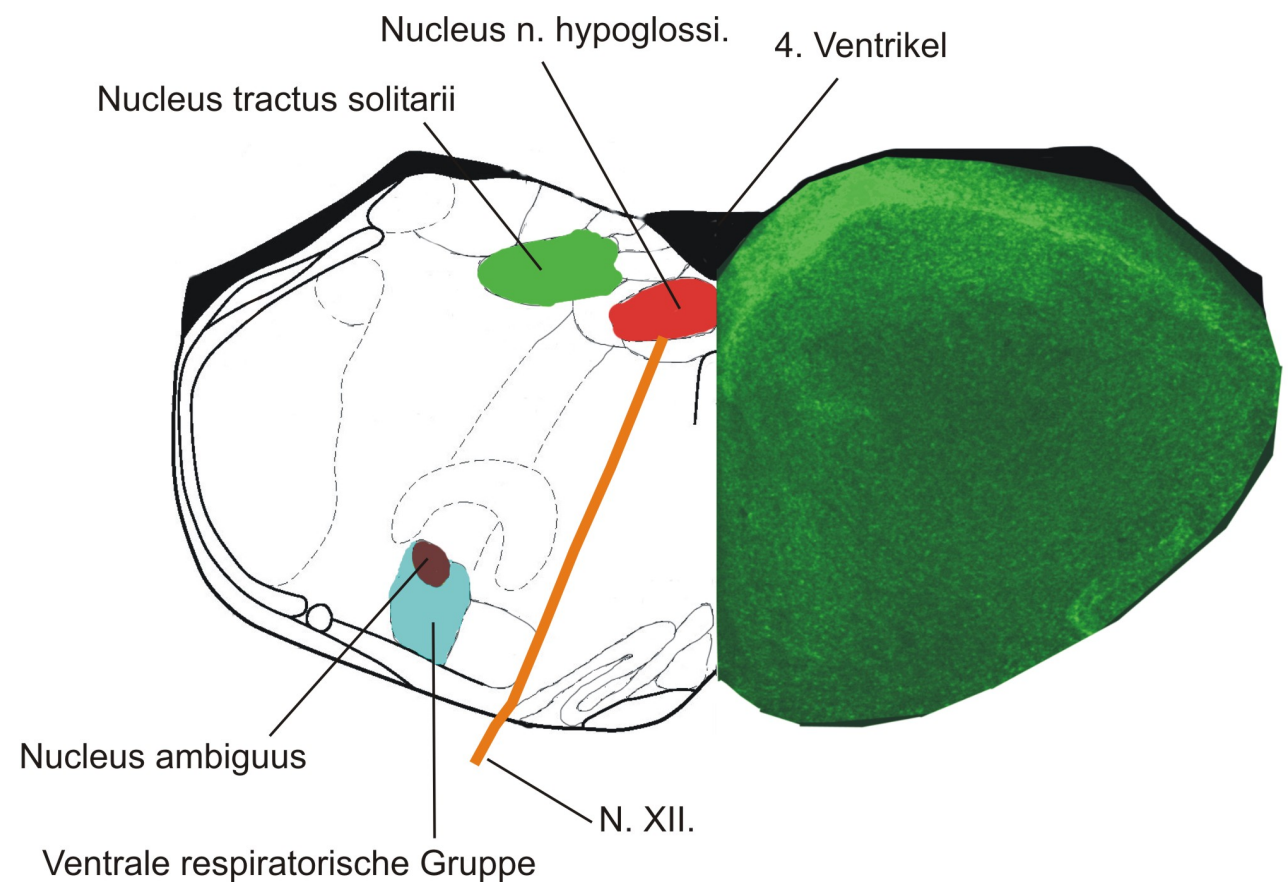

Abb. 1: Schematische Übersicht mit anatomischen Bezeichnungen (links) und Querschnitt (rechts) durch den Hirnstamm einer neonatalen Maus der TgN(hGFAP-EGFP)-Linie. In der Übersicht ist die Lage der in dieser Arbeit berücksichtigten Kerngebiete sowie der zur Orientierung nötigen Leitstrukturen angegeben.

Dem sich ständig wiederholenden Atemzyklus liegt ein basaler Atemrhythmus zugrunde. Dieser wird bei Säugern in der Medulla oblongata generiert wird und von anderen Gebieten des ZNS moduliert (Bianchi et al. 1995).

Die zentrale Kontrolle der Säugeratmung lässt sich in drei Phasen einteilen. Die inspiratorische, die postinspiratorische und die exspiratorische Phase, die einen Atemzyklus darstellen, werden durch 
die aktive Exspiration bei Modulation der Atmung $\mathrm{zu}$ verschiedenen Zwecken (Husten, Lautbildung) (Schmidt et al. 2005) ergänzt.

An der Ventilation der Lunge ist neben der Atemmuskulatur auch Muskulatur zur Freihaltung der Luftwege beteiligt. Diese ist zum Teil mit der Atmungsaktivität koordiniert und führt zum Beispiel zu einer atemsynchronen Aktivität der Zungengrundmuskulatur durch den zwölften Hirnnerven (Nervus hypoglossus; N. XII; Abb. 1).

Mehrere Kerngebiete sind in der Medulla für die Generation und Modulation des Atemrhythmus sowie die motorische Kontrolle der Atmung verantwortlich. Dazu zählen die dorsale respiratorische Gruppe (DRG) und die ventrale respiratorische Gruppe (VRG; Abb. 1).

Die VRG besteht aus einem kaudalen, einem intermediären und einem rostralen Anteil, wobei der rostrale Anteil sich in den Bötzinger Komplex und den Prä-Bötzinger Komplex (PBC) aufteilt. Mit Hilfe der Hirnstammpräparation konnte nachgewiesen werden, dass der PBC für die Generierung des Atemrhythmus essentiell ist (Smith et al.1991).

Die VRG lässt sich in der ventralen kaudalen Medulla oblongata in Höhe des unteren Drittels des vierten Ventrikels, ventro-medial des Nucleus ambiguus und lateral der inferioren Olivenkerne finden (Abb. 1). Die VRG wie auch der PBC bilden ein funktionelles Kerngebiet und lassen sich kaum durch anatomische Eigenschaften von anderen Kerngebieten abgrenzen, am ehesten durch die erhöhte Expression von NK-1-Rezeptoren im PBC (Gueyenet und Wang 2001).

\subsubsection{Elektrophysiologische Eigenschaften des respiratorischen}

\section{Netzwerks}

Die synchrone elektrophysiologische Aktivität einzelner Neuronengruppen (prä-, früh-, rampen-, spät- und post-inspiratorische sowie exspiratorische Neurone) im respiratorischen Netzwerk kann sich an die Anforderungen des Körpers anpassen, sowohl situativ als auch im Zuge der Entwicklung des Organismus. Während dieser synchronen Aktivität („Bursts“) wird wiederholt durch die bei Aktionspotentialen zur Repolarisierung der Neurone nötigen $\mathrm{K}^{+}$-Auswärtsströme die 
extrazelluläre $\mathrm{K}^{+}$-Konzentration in diesen Hirngebieten angehoben (gezeigt in vitro und in vivo; Richter et al. 1978; Brockhaus et al. 1993). Dies geschieht mit einer hohen Frequenz, mit bis zu 6 Atemzyklen pro Sekunde bei neonatalen Mäusen.

Während der elektrischen Aktivität der Neurone werden außerdem im Zuge der synaptischen Aktivität Transmittersubstanzen ausgeschüttet. Im respiratorischen Netzwerk findet sich eine große Vielfalt an Neurotransmittern und Neuromodulatoren. Der wichtigste exzitatorische Transmitter ist dort Glutamat, welches im Zuge der rhythmischen Aktivität repetitiv ausgeschüttet wird (Greer et al. 1992; Koshiya und Smith 1999; Richter und Spyer 2001)

Da sowohl extrazelluläre Kalium-Ionen (Rybak et al. 2003) als auch Glutamat einen Einfluss auf das neuronale Membranpotential haben, haben sie somit auch eine Wirkung auf die neuronale Aktivität und können damit den Atemrhythmus modulieren. So sind unterschiedliche Expressionsmuster von verschiedenen Ionenkanälen und ionotropen sowie metabotropen GlutamatRezeptoren im Hirnstamm beschrieben (Robinson und Ellenberger 1997; Dong und Feldman 1999).

\subsection{Eigenschaften von Astrozyten}

Astrozyten sind Gliazellen und gehören damit zu den vier Zellgruppen nach Hortega (Neurone, Oligodendrozyten, Astrozyten, Mikroglia), aus denen das ZNS besteht. Neben den oben genannten Zellen sind den Astrozyten verwandte Gliazellen in speziellen Regionen des ZNS beschrieben, so z.B. die Müller-Zellen in der Retina und die Bergmann-Gliazellen im Kleinhirn.

Astrozyten verfügen über eine Vielzahl von Funktionen, mit denen die Integrität des ZNS aufrecht erhalten wird. Neben der Bildung von Strukturgewebe sowie von Narbengewebe nach Traumata (Gliose) sind Astrozyten an der Blut-Hirnschranke beteiligt. Sie erfüllen nutritive Funktionen und haben einen großen Anteil an der Homöostase der Ionen- und Neurotransmitter-Konzentrationen im extrazellulären Raum. Große Gruppen von Astrozyten sind über Gap-Junctions miteinander verknüpft und bilden so ein Synzytium, über das lokale Konzentrationssteigerungen von $\mathrm{K}^{+}$-Ionen, 
entstanden z.B. durch synchrone neuronale Aktivität, abgepuffert werden können. Dieser Vorgang nennt sich „Spatial K-Buffering“ (Kofuji und Newman 2004).

Durch die Expression glialer Glutamat-Transporter (GLAST (EAAT1), GLT-1 (EAAT2)) haben Astrozyten ebenfalls die Möglichkeit, mittels Glutamataufnahme aus dem synaptischen Spalt zu hohe Glutamat-Konzentrationen zu vermeiden und damit die synaptische Aktivität zu stabilisieren (Kullmann und Asztely 1998; Rusakov und Kullmann 1998, Hulsmann et al. 2000 b).

Eng verknüpft mit der Aufnahme von extrazellulären Transmittern wie Glutamat ist auch deren Metabolisierung und die Rückführung an benachbarte Neurone. Eine pharmakologische Unterbrechung dieses Transmitter-Metabolismus führt zu einer Störung der neuronalen NetzwerkAktivität (Funk et al. 1993, Hulsmann et al. 2000 a).

\subsection{Fragestellung}

Das respiratorische Nervensystem zeichnet sich durch eine andauernde und lebenswichtige rhythmische neuronale Netzwerkaktivität aus. Welche Rolle spielen Astrozyten in der Stabilisierung, der Modulation und der Plastizität der Netzwerkaktivität sowie bei dort stattfindenden pathophysiologischen Vorgängen?

Um diese Fragen beantworten zu können, ist eine detaillierte Beschreibung der in Respirationsassoziierten Kerngebieten des Hirnstamms anzutreffenden Astrozyten vonnöten. Neben einer grundlegenden anatomischen Beschreibung dieser Zellen müssen diese dabei vor allem auf einige basale funktionelle Aspekte hin untersucht werden. Dazu zählen die Expression von MembranKanälen und Transportern zur Regulierung der extrazellulären $\mathrm{K}^{+}$- und Glutamat-Konzentrationen. Es ist bekannt, dass Astrozyten in anderen Hirngebieten keine einheitliche Population bieten (Matthias et al. 2003, Zhou und Kimelberg 2000; Zhou und Kimelberg 2001). Lassen sich auch im respiratorischen Netzwerk unterschiedliche Zellpopulationen und/oder Differenzierungsstufen von Astrozyten beschreiben und sind letztendlich die Eigenschaften „respiratorischer“ Astrozyten vergleichbar mit denen in anderen ZNS-Arealen? 


\section{Material und Methoden}

\subsection{Die TgN(hGFAP-EGFP)-Maus}

Um Astrozyten im Hirngewebe von Mäusen für elektrophysiologische Experimente identifizieren zu können, wurden Mäuse einer transgenen Linie als Versuchstiere verwendet. Die TgN(hGFAPEGFP)-Mäuse exprimieren das grün fluoreszierende Protein EGFP (enhanced green fluorescent

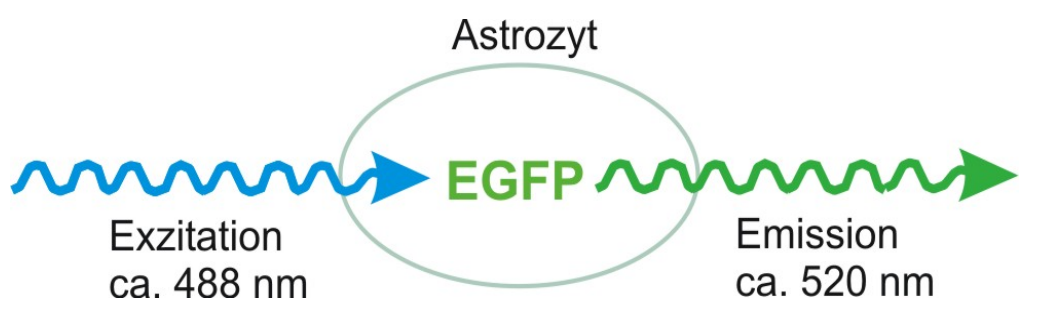

Abb. 2: Schematische Darstellung der Anregung des in Astrozyten unter dem humanen GFAP-Promoter exprimierten grünen Fluoreszenz-Farbstoffes EGFP. protein) aus der Qualle Aequorea Victoria unter der Kontrolle des humanen GFAP (glial fibrillary acidic protein)-Promotors.

GFAP ist ein akzeptiertes Marker-Protein für Astrozyten. Die TgN(hGFAP-EGFP)-Mauslinie wurde in der Arbeitsgruppe von Privatdozent Dr. Frank Kirchhoff und Prof. Dr. Helmut Kettenmann am Max-Delbrück-Institut Berlin entwickelt (Nolte et al. 2001) und freundlicherweise zur Verfügung gestellt.

Regt man den in den Astrozyten produzierten Fluoreszenzfarbstoff EGFP mit Licht der Wellenlänge 467-488 nm an, so zeigen diese Zellen eine grüne Fluoreszenz (Abb. 2). Diese grüne Fluoreszenz ermöglicht eine leichte Identifizierung von Astrozyten sowie eine Beurteilung der Morphologie dieser Zellen in vitalem Gewebe. Ebenso lassen sich z.B. für immunhistochemische Färbungen mittels konfokaler Laserscanning-Mikroskopie selbst kleine Fortsätze der Zellen darstellen.

Der Vorteil der Verwendung der transgenen Mauslinie und der Fluoreszenz-Mikroskopie gegenüber der Durchlicht-Mikroskopie von nicht fluoreszierendem Hirngewebe liegt in der eindeutigen Identifizierung von Astrozyten sowie der guten Abgrenzbarkeit zu anderen Zelltypen, vor allem zu anderen Gliazellen im ZNS. Dies ermöglichte eine umfassende elektrophysiologische und immunhistochemische Analyse der Astrozyten im respiratorischen Netzwerk der Maus. 


\subsection{Elektrophysiologische Analyse von Astrozyten im}

\section{respiratorischen Netzwerk}

\subsubsection{Präparation von Hirnstammschnitten}

Für die elektrophysiologische Analyse von Astrozyten im respiratorischen Netzwerk wurde Gewebe aus Hirnstämmen von TgN(hGFAP-EGFP)-Mäusen im Alter von null bis zwölf Tagen entnommen (Abb. 3). Das Alter wurde im Folgenden in Tagen nach der Geburt angegeben $(\mathrm{px}=$ postnataler Tag x). Die Mäuse wurden dekapitiert, wobei Tiere, die älter als p10 waren, vorher mit Äther narkotisiert wurden. Nach sagittaler Auftrennung der Kopfschwarte wurde mit einer Schere

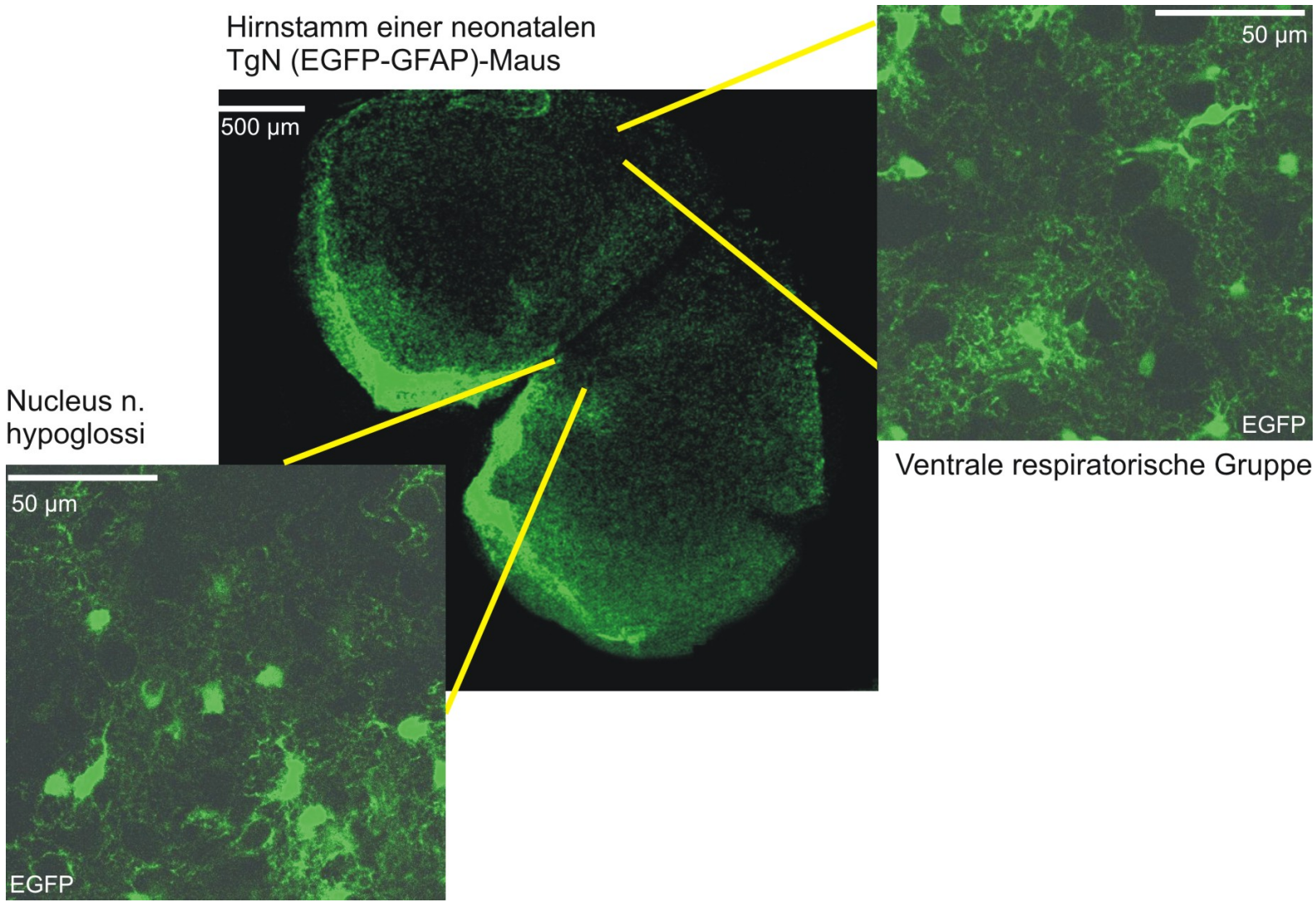

Abb. 3: Grün fluoreszierende Astrozyten im Hirnstamm einer TgN(hGFAP-EGFP)-Maus mit per konfokales LaserscanningMikroskop angefertigten Beispielabbildungen aus dem Nucleus n. hypoglossi und der ventralen respiratorischen Gruppe.

die Schädeldecke entfernt, das Großhirn aus dem Schädel herausgehoben und nach Durchtrennung der Hirnnerven der Hirnstamm von der Schädelbasis abpräpariert. Das Gehirn inklusive kranialer Rückenmarksanteile wurde in gekühlten Carbogen-Gas $\left(95 \% \mathrm{O}_{2}, 5 \% \mathrm{CO}_{2}\right)$-gesättigten artifiziellen zerebrospinalen Liquor (aCSF; Zusammensetzung siehe Tab. 1) gebracht. 


\begin{tabular}{|c|c|c|c|c|c|c|c|c|c|c|c|c|}
\hline Lösung & $\mathrm{NaCl}$ & $\mathrm{KCl}$ & $\mathrm{CaCl}_{2}$ & $\mathrm{MgCl}_{2}$ & $\mathrm{NaHCO}_{3}^{-}$ & $\mathrm{NaH}_{2} \mathrm{PO}_{4}^{-}$ & D-Glukose & HEPES & $\mathrm{Na}^{+} \mathbf{2 A T P}$ & EGTA & pH-Wert & $\begin{array}{c}\text { Osmolarität } \\
(\operatorname{mosm} / l)\end{array}$ \\
\hline$A C S F$ & 118 & 3 & 1.5 & 1 & 25 & 1 & 30 & - & - & - & $7.4 *$ & 330 \\
\hline $\begin{array}{c}\text { HEPES- } \\
\text { gepufferte } \\
\text { aCSF }\end{array}$ & 118 & 3 & 1.5 & 1 & - & - & 30 & 25 & - & - & $7.4 * *$ & 330 \\
\hline $\begin{array}{c}\text { Intra- } \\
\text { zelluläre } \\
\text { Lösung }\end{array}$ & - & 125 & 1 & 2 & - & - & - & 10 & 4 & 10 & $7.2 * * *$ & $300-310$ \\
\hline
\end{tabular}

Tab. 1: In elektrophysiologischen Versuchen verwendete Lösungen. Abkürzungen: aCSF: artifizielle zerebrospinale

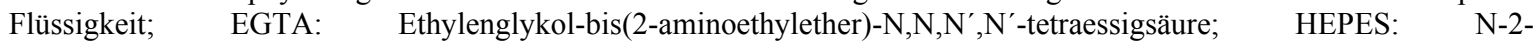
Hydroxyethylpiperazin-N'-2-ethansulfonsäure; *: eingestellt mit $\mathrm{NaOH}$, nach Sättigung mit Carbogen-Gas $\left(95 \% \mathrm{O}_{2}, 5\right.$ $\left.\% \mathrm{CO}_{2}\right)$; **: eingestellt mit NaOH; eingestellt mit KOH. Bezug der Substanzen über Sigma, Deisenhofen.

Zunächst wurden das Groß- und Mittelhirn durch einen Schnitt durch die Vierhügelplatte entfernt.

Das Kleinhirn wurde vom Hirnstamm abgetrennt. Der Hirnstamm wurde mit Cyanoacrylat-Kleber (Loctite Deutschland GmbH, München) mit der dorsalen Seite auf einem Agarblock fixiert und in eine aCSF-gefüllte Schnittkammer eingespannt. Mit einem Vibratom (Campden Instruments, Loughborough, Großbritannien) wurden pro Hirnstamm zwei bis vier transversale Gewebeschnitte mit einer Schichtdicke von ca. $200 \mu \mathrm{M}$ aus der kaudalen Medulla oblongata in Höhe des unteren Drittels des vierten Ventrikels angefertigt. Das gewonnene Gewebe wurde für nicht mehr als 6 Stunden bei Raumtemperatur $\left(21-24^{\circ} \mathrm{C}\right)$ in carbogenisierter aCSF aufbewahrt. Nach Überführung in die Messkammer wurden die Schnitte dort mit einem U-förmigen Gitter aus Platindraht und Nylonfasern fixiert (Edwards et al. 1989). Die Messkammer wurde bei Raumtemperatur kontinuierlich mit carbogenisierter aCSF durchspült (Flussrate etwa $5-10 \mathrm{ml} / \mathrm{min}$ ). Die kontinuierliche Zirkulation der aCSF wurde durch eine Rollenpumpe (Verder, Düsseldorf) sichergestellt. Die Messkammer stand unter einem aufrechten Mikroskop (Axioscope FS, Zeiss, Oberkochen), ausgestattet mit 63x und 40x Achroplan W sowie 5x Achroplan Objektiven (Zeiss). Astrozyten wurden im Schnitt durch ihre grüne Fluoreszenz nach Anregung durch blaues Auflicht (467 bis $488 \mathrm{~nm}$ ) aus einem computergesteuerten Monochromator (Polychrome II, TILL Photonics, Gräfelfing) identifiziert. Mittels einer am Mikroskop angebrachten CCD-Kamera (MicroMax, Princeton Instruments, Trenton, New Jersey, USA) wurden digitale Bilder der untersuchten Zellen angefertigt. 
Neurone wurden anhand morphologischer Kriterien (Form und Größe des Somas) in der DurchlichtMikroskopie im Hirnstammgewebe identifiziert.

Das Kerngebiet des Nucleus n. hypoglossi wurde in kaudalen Schnitten des vierten Ventrikels in Höhe der Area postrema anhand der großen Motoneuronen seitlich der Mittellinie identifiziert. Die ventrale respiratorische Gruppe wurde in Höhe des unteren Drittels des vierten Ventrikels anhand ihrer ventromedialen Lage zu den Motoneuronen im Nucleus ambiguus lateral der Olivenkerne identifiziert (Abb. $1)$.

\subsubsection{Whole-Cell-Voltage-Clamp-Ableitungen von Astrozyten}

Zur Analyse elektrophysiologischer Parameter von Astrozyten und Neuronen wurden Whole-CellVoltage-Clamp-Experimente (Spannungs-Klemme in der Ganz-Zell-Konfiguration) durchgeführt (Abb. 4).

Mit dieser Technik lassen sich transmembranöse Ionenströme unabhängig von Membranpotentialschwankungen registrieren. Dazu wird ein Potential zwischen zwei Elektroden gemessen. Eine Silber-Silberchlorid-Elektrode befindet sich in der Patch-Pipette, welche elektrisch dem intrazellulären Raum entspricht, eine andere liegt in der Bad-Lösung, d.h. im extrazellulären Raum. An einem Verstärker wird ein Haltepotential $\left(V_{h}\right)$ vorgegeben, welches mittels Strominjektion des Verstärkers konstant gehalten (,geklemmt“) wird. Der zu injizierende Strom wird durch Vergleich des gemessenen aktuellen Membranpotentials und des vorgegebenen Haltepotentials mittels einer Rückkopplungsschaltung definiert.

Zur Whole-Cell-Voltage-Clamp-Messung wurden Pipetten mit einem programmierbaren Horizontal-Elektrodenziehgerät (Zeitz-Instrumente, München) aus Borosilikat-Glaskapillaren (Biomedical Instruments, Zülpich) hergestellt. Die benutzten Pipetten hatten einen Widerstand von 2,5-8 M $\Omega$ und wurden mit Intrazellularlösung (Zusammensetzung siehe Tab. 1) gefüllt.

Um vor der Messung eine Verschmutzung der Pipettenöffnung zu vermeiden, wurde die Pipette mit leichtem Überdruck (15-25 mmHg) in die Badlösung getaucht. Nach der Korrektur des 
Offsetstroms wurde dann die Pipette mit Hilfe eines 3D-Mikromanipulators direkt an die Zellmembran herangeführt. Wird dann der Überdruck vermindert, legt sich die Zellmembran, gegebenenfalls unter Zuhilfenahme von leichtem Unterdruck, an die Pipettenöffnung.

Bei dieser Annäherung der Pipette an die Zellmembran steigt der elektrische Widerstand zwischen Pipetten-Elektrode und Bad-Elektrode und erreicht schließlich Werte von mehr als 1 G $\Omega$ (gigaseal). Nach Kompensation der Pipettenkapazitäten (fast capacitance compensation) kann nun durch einen kurzen Unterdruckpuls die Zellmembran unter der Pipettenöffnung eingerissen werden und die Whole-Cell-Konfiguration hergestellt werden. Anschließend wurde die Membrankapazität (whole cell capacitance) kompensiert. Die Kompensation erfolgte bei Messungen mit dem Multiclamp 700 durch manuelle Änderung der Variablen Kapazität der Zellmembran $\left(\mathrm{C}_{\mathrm{m}}\right)$ und Serienwiderstand der Zelle $\left(\mathrm{R}_{\mathrm{s}}\right)$ in der Kompensationsfunktion der Verstärkersteuerung.

Um den Pipettenwiderstand in der Badlösung, nach Erreichen des Giga-Seals sowie Kompensation der Elektrodenkapazität und in der Whole-Cell-Konfiguration zu kontrollieren, wurde ein Testpuls mit einer Spannung von $5 \mathrm{mV}$ und einer Dauer von $10 \mathrm{~ms}$ angelegt.

Die gemessenen Ströme wurden verstärkt, über ein Interface mit AD/DA-Wandler digitalisiert (Digidata 1322 A, Axon Instruments, Inc. Foster City, CA, USA), um sie dann mit Hilfe von Auswertungsprogrammen (s.u.) am Computer analysieren zu können. Es wurde ein diskontinuierlicher Verstärker für Current- und Voltage-Clamp-Experimente (NPI SEC-05L; Tamm, Deutschland; Frequenz 40-50 kHz; duty cycle: 25\%)) oder ein kontinuierlicher Verstärker (Multiclamp 700A; Axon Instruments, Inc., Foster City, CA, USA) verwendet. Ein kontinuierlicher Verstärker injiziert und misst den zur Erhaltung des Membranpotentials nötigen Strom (voltage clamp) simultan. Dies führt dazu, dass das Membranpotential durch den Serienwiderstand verfälscht wird. Es ist eine Serienwiderstandkompensation notwendig. Ein diskontinuierlicher Verstärker misst das Membranpotential zu einem Zeitpunkt, an dem kein Strom injiziert wird. Somit lässt sich das Membranpotential unabhängig vom Serienwiderstand ermitteln. Ein Nachteil eines diskontinuierlichen Verstärkers ist sein wesentlich höheres Rauschen. 
Die meisten Astrozyten besitzen eine sehr hohe Membranleitfähigkeit und damit einen geringen Eingangswiderstand, der sogar geringer als der Serienwiderstand sein kann. Die übliche Formel zur Kompensation des Serienwiderstandes $\mathrm{R}_{\mathrm{s}}$ setzt einen hohen Membranwiderstand $\mathrm{R}_{\mathrm{M}}$ voraus, der wesentlich größer sein muss als der Serienwiderstand. Damit ist es mit dem Algorithmus zur Kompensation des Serienwiderstands der Verstärkersteuerung des Multiclamp 700A nicht möglich, bei diesen Zellen den Serienwiderstand zu bestimmen und zu kompensieren.

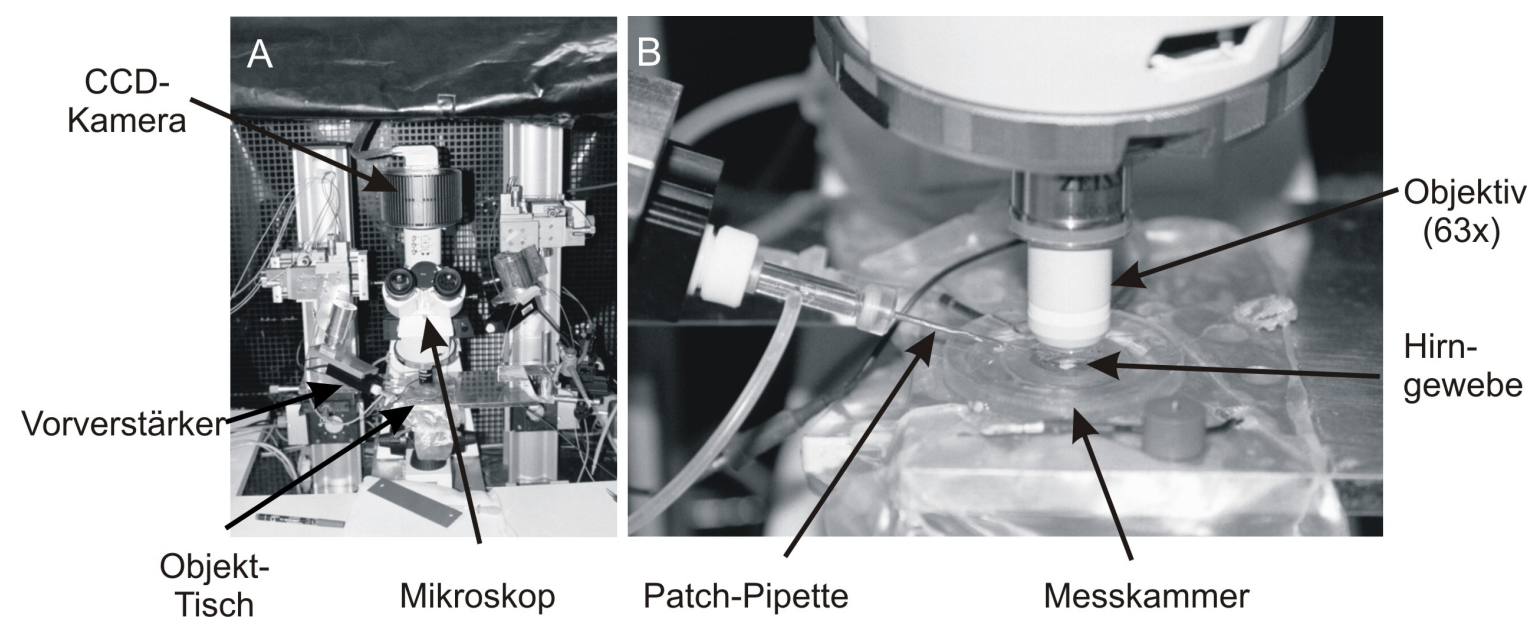

Abb. 4: Prinzipieller Aufbau des elektrophysiologischen Messplatzes A: Mikroskop (Axioscop FS1) in Faradayschem Käfig mit verstellbarem Objekttisch, Vorverstärker und Elektrodenhalterung (Headstage) sowie einer CCD-Kamera zur Aufnahme von Bildern durch das Mikroskop. B: Detailaufnahme der Messsituation mit Messkammer, Hirnstammgewebe, Patch-Clamp-Pipette 


\subsubsection{Untersuchung der elektrophysiologischen Eigenschaften von}

\section{Astrozyten}

Per definitionem wurde das Ruhemembranpotential als das Membranpotential bestimmt, an dem im Whole-Cell-Voltage-Clamp-Modus kein Nettostrom über der Zellmembran der untersuchten Zelle fließt. Dieses Membranpotential wurde aus der Stromspannungskurve durch graphische Interpolation ermittelt. Der Eingangswiderstand der Zellen wurde nach dem Ohmschen Gesetz aus dem bei einem Spannungssprung von $-80 \mathrm{mV}$ auf $-90 \mathrm{mV}$ ausgelösten Steady-State-Strom $\left(\mathrm{I}_{\mathrm{ss}}\right)$ errechnet. Bei diesen Membranspannungen sind kaum spannungsgesteuerte Kanäle geöffnet.

A

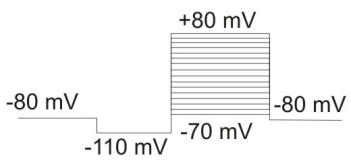

B

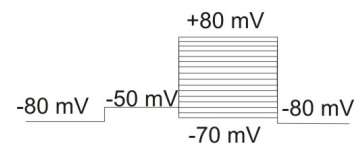

C

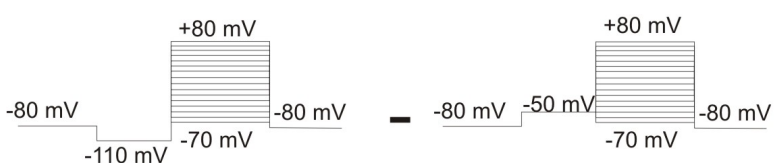

Abb. 5: Protokoll zur Isolierung des A-Typ- $\mathrm{K}^{+}-$Stroms in Astrozyten während eines Whole-Cell-Voltage-ClampExperiments. A: Spannungspulse von $-70 \mathrm{mV}$ bis $+80 \mathrm{mV}$ (10-mV-Schritte) mit hyperpolarisierendem Vorpuls auf $110 \mathrm{mV}$. B: Die gleichen Spannungspulse mit depolarisierendem Vorpuls auf $-50 \mathrm{mV}$ C: Punkt-zu-PunktSubtraktion von A und B zur Darstellung des isolierten ATyp-K $\mathrm{K}^{+}$-Stroms.
Da sich viele Ionenkanäle der Zellmembran spannungsabhängig öffnen, wurden die Membranleitfähigkeiten der Zellen bei verschiedenen Membranpotentialen gemessen. Dafür wurden die Zellen von einem Haltepotential von $-80 \mathrm{mV}$ für je 100 ms bzw. 200 ms auf Membranpotentiale von $170 \mathrm{mV}$ bis $+70 \mathrm{mV}$ (in $10-\mathrm{mV}-$ Schritten) geklemmt. Die Amplituden der bei den verschiedenen Spannungen gemessenen Ströme wurden gegen die angelegte Spannung aufgetragen.. Dabei wurden die Stromamplituden zu Beginn und am Ende der Spannungssprünge verwendet .

Zur Analyse des A-Typ-K ${ }^{+}$-Stroms wurde ein Subtraktions-Strom-Spannungs-Protokoll mit deund hyperpolarisierenden Vorpulsen verwendet (Bordey und Sontheimer 1999; Bordey und Sontheimer 2000; Abb. 5). Dazu wurden die in Whole-Cell-Voltage-Clamp-Experimenten auf einem Membranpotential von $-80 \mathrm{mV}$ gehaltenen Zellen nach einem hyperpolarisierenden Spannungssprung (100ms) auf -110 mV mehreren $200 \mathrm{~ms}$ andauernden Membranpotentialen von $-70 \mathrm{mV}$ bis $+80 \mathrm{mV}$ (10-mV-Schritte) ausgesetzt. Anschließend wurden die Zellen einem 
depolarisierenden Spannungssprung $(-50 \mathrm{mV}$ Spannung, $100 \mathrm{~ms}$ Dauer $)$, gefolgt von Membranpotentialen von $-70 \mathrm{mV}$ bis $+80 \mathrm{mV}$ ausgesetzt. Durch den hyperpolarisierenden Vorpuls werden sämtliche spannungsabhängigen auswärts-gleichrichtenden $\mathrm{K}^{+}$-Kanäle de-inaktiviert, um danach bei den folgenden verschiedenen Membran-Spannungen aktiviert zu werden. Durch den depolarisierenden Vorpuls werden die schnellen A-Typ-K ${ }^{+}$-Kanäle aktiviert und sind damit während der folgenden Spannungssprünge inaktiviert. Dort zeigen sich jetzt nur die langsamen spannungsabhängigen $\mathrm{K}^{+}$-Ströme sowie die passiven, nicht spannungsabhängigen Leitfähigkeiten. Durch eine Punkt-zu-Punkt-Subtraktion der aus dem Protokoll resultierenden Ströme können nun die schnellen A-Typ- $\mathrm{K}^{+}$-Ströme dargestellt werden.

\subsubsection{Applikation von Substanzen während elektrophysiologischer Experimente}

Um die untersuchten Gewebe der Wirkung bestimmter Substanzen auszusetzen, wurden verschiedene Applikationstechniken verwendet. Die Substanzen, ihre Konzentration und Applikationstechnik sind in Tab. 2 aufgeführt.

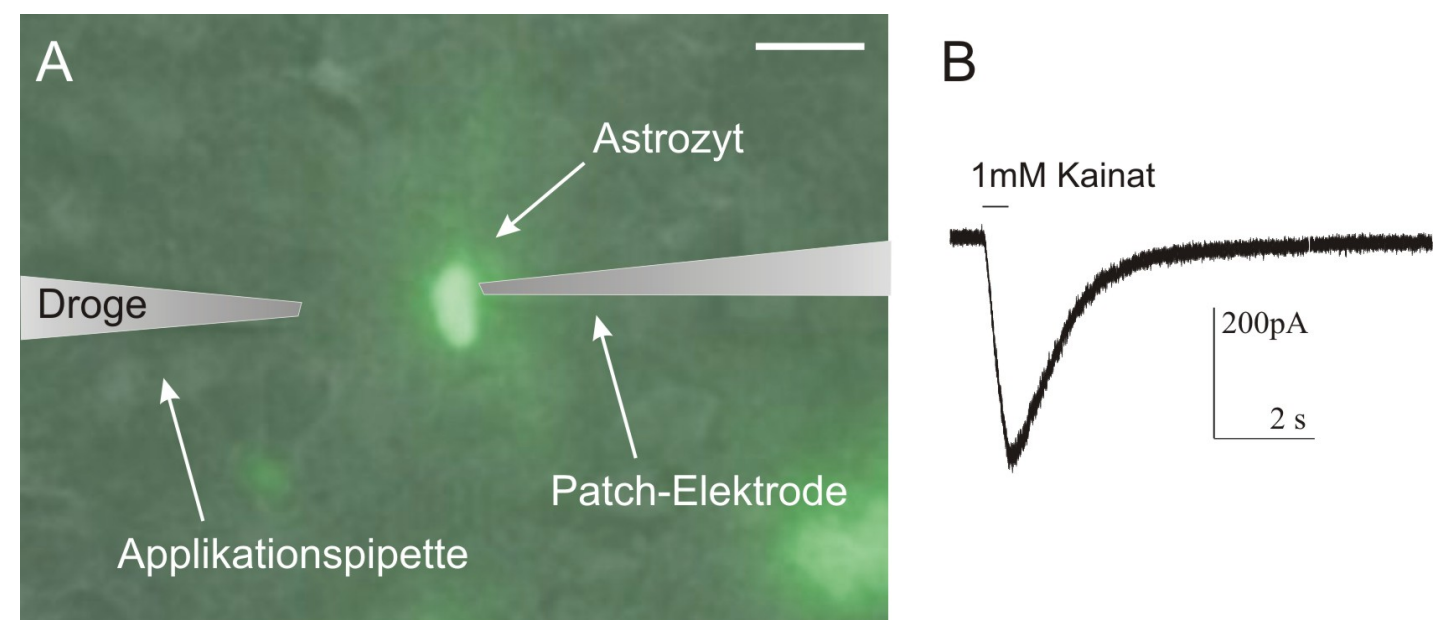

Abb. 6: A: Schema der gezielten lokalen Druckapplikation von Substanzen auf EGFP-exprimierende Astrozyten. B: Typische Stromantwort eines Astrozyten nach Applikation von $1 \mathrm{mM}$ Kainat. Länge des Messbalkens in A: $20 \mu \mathrm{m}$. 
Bei der Badapplikation von Substanzen erreichte die zirkulierende Lösung ca. 30 Sekunden nach der Zugabe der Stoffe zur Badlösung das Schnittpräparat und konnte durch frische Badlösung wieder ausgewaschen werden.

So wurden durch D-Aspartat hervorgerufene Membranströme in den Astrozyten gemessen. Nach der Gabe des Ionenkanalblockers 4-AP wurden Stromspannungskurven der untersuchten Zellen aufgezeichnet. Nach Auswaschen der Substanzen wurden erneut Stromspannungskurven aufgezeichnet, um eine Reversibilität der Veränderungen zu untersuchen. Zusätzlich wurde eine lokale Applikationstechnik angewendet. Aus einer Pipette (Öffnungsdurchmesser ca. $2 \mu \mathrm{m}$,

\begin{tabular}{|c|c|c|c|}
\hline Substanz & Konzentration & Wirkweise & Applikation \\
\hline Tetrodotoxin $(T T X)(1)$ & $500 \mathrm{nM}$ & Blockade von $\mathrm{Na}^{+}$-Kanälen & Badapplikation \\
\hline Cadmiumchlorid ( $\mathrm{CdCl}_{2}$ ) (3) & $100 \mu \mathrm{M}$ & Blockade von $\mathrm{Ca}^{2+}$-Kanälen & Badapplikation \\
\hline 4-Aminopyridin (4-AP) (3) & $2 \mathrm{mM}$ & Blockade von $\mathrm{K}_{\mathrm{A}}^{+}$-Kanälen & Badapplikation \\
\hline L-Glutamat (3) & $1 \mathrm{mM}$ & $\begin{array}{l}\text { Agonist und Substrat für Glutamat- } \\
\text { Rezeptoren und Transporter }\end{array}$ & Druckapplikation \\
\hline D-Aspartat (3) & $1 \mathrm{mM}$ & Substrat von Glutamat-Transportern & Badapplikation \\
\hline Kainat (3) & $1 \mathrm{mM}$ & $\begin{array}{c}\text { Agonist für AMPA/KA-Glutamat- } \\
\text { Rezeptoren }\end{array}$ & Druckapplikation \\
\hline $\begin{array}{c}\text { 2-Amino-5-phosphonopentanoinsäure } \\
\text { (AP5) (2) }\end{array}$ & $50 \mu \mathrm{M}$ & $\begin{array}{c}\text { Blockade von NMDA-Glutamat- } \\
\text { Rezeptoren }\end{array}$ & Badapplikation \\
\hline $\begin{array}{c}\text { 6-Cyano-7-nitro-quinoxalin-2,3-dion } \\
(C N Q X)(2)\end{array}$ & $50 \mu \mathrm{M}$ & $\begin{array}{c}\text { Blockade von AMPA/KA-Glutamat- } \\
\text { Rezeptoren }\end{array}$ & Badapplikation \\
\hline Dihydrokainat (DHK) (3) & $300 \mu \mathrm{M}$ & $\begin{array}{c}\text { Blockade von GLT-1-Glutamat- } \\
\text { Transportern }\end{array}$ & Badapplikation \\
\hline$\beta$-Threo-hydroxyaspartat (THA) (3) & $50 \mu \mathrm{M}$ & $\begin{array}{l}\text { Kompetitiver Antagonist für } \\
\text { Glutamat-Transporter }\end{array}$ & Badapplikation \\
\hline Bicucullin (3) & $20 \mu \mathrm{M}$ & Blockade von $\mathrm{GABA}_{\mathrm{A}}$-Rezeptoren & Badapplikation \\
\hline Strychnin (3) & $10 \mu \mathrm{M}$ & Blockade von Glycin-Rezeptoren & Badapplikation \\
\hline
\end{tabular}

Tab. 2: In elektrophysiologischen Experimenten verwendete Substanzen. Bezug der Substanzen über (1): Alomone Labs Ltd., Jerusalem, Israel), (2): Tocris Cookson Ltd., Bristol, Großbritannien, (3): Sigma, Deisenhofen.

Entfernung zur Zielzelle: ca. $50 \mu \mathrm{m}$ ) wurden in HEPES-gepufferter aCSF (pH-Wert 7.4, Osmolarität 330 mosm/l) gelöste Substanzen (Glutamat, Kainat) durch einen Druckpuls (Druck 0.2 bar, Dauer 0.5 Sekunden) gezielt auf die untersuchte Zelle appliziert (Abb. 6). 


\subsection{Morphologische Untersuchungen und Immunhistochemie}

\subsubsection{Immunfärbungen}

Für immunhistochemische Fluoreszenzfärbungen an 30-60 $\mu \mathrm{m}$ dicken Hirnschnitten wurden TgN(hGFAP-EGFP)-Mäuse im Alter zwischen 2 und 23 Tagen mit $4 \%$ Paraformaldehyd perfundiert. Nachdem der Maus zur Anästhesierung $100 \mu 1 / 10$ g Körpergewicht $2.5 \%$ 2,2,2Tribromethanol in die Peritonealhöhle injiziert wurde, konnte durch Eröffnung des Thorax das Herz freigelegt werden. Mittels einer Kanüle, die in die linke Herzkammer der Maus eingeführt wurde, konnten nach Anschneiden des rechten Vorhofs die Gefäße des Körperkreislaufs genutzt werden, um eine gleichmäßige Perfusion des Körper- und vor allem Hirngewebes mit Fixationsmittel zu gewährleisten. Zuerst wurde die Maus zum Auswaschen des Blutes 2 Minuten mit HBSS (Hank's Balanced Salt Solution) und danach zur Fixierung für 15 Minuten mit dem Fixationsmittel $4 \%$ Paraformaldehyd (PFA) in Natrium-Phosphat-Puffer (PBS) perfundiert. Nach erfolgter Fixierung wurde das Hirn in toto herauspräpariert und bei $4^{\circ} \mathrm{C}$ für weitere 2 Stunden in 4 $\%$ PFA in Phosphat-gepufferter isotoner NaCl-Lösung (PBS; phosphate-buffered saline) nachfixiert.

Nun konnte analog der Präparation für elektrophysiologische Experimente (s.o.) das Großhirn durch einen Schnitt in Höhe der Vierhügelplatte entfernt und der Hirnstamm sowie das Kleinhirn auf die Schnittfläche gestellt und mit Klebstoff fixiert werden. Mit einem Vibratom (Leica VT 1000S, Leica Instruments, Nussloch, Deutschland) wurde nun von kaudal eine Serie von 30-60 $\mu \mathrm{m}$ dicken Hirnschnitten gefertigt, aus denen pro Färbung etwa 10-15 Schnitte ausgewählt wurden, die die VRG und/oder den Nucleus n. hypoglossi enthielten. Die so gewonnenen 30-60 $\mu$ m dicken Schnitte sowie die $200 \mu \mathrm{m}$ dicken Schnitte aus den elektrophysiologischen Experimenten wurden nun bei Raumtemperatur gefärbt. Die Schnitte wurden zuerst für 30 Minuten in einer $0.4 \%$-Lösung des Detergenz Triton x100 permeabilisiert und danach für 30 Minuten in $0.2 \%$ Triton x100 und 10 \% fetalem Kälberserum (FCS) in PBS geblockt. Nun wurden die Schnitte bei $4^{\circ} \mathrm{C}$ über Nacht in einer Lösung mit dem Erstantikörper in 0.5 \% Triton x100 und 2 \% FCS inkubiert. 
Die verwendeten Erst- und Zweitantikörper und ihre Konzentrationen sind in der Tab. 3 angegeben. Am folgenden Tag wurde das Gewebe zweimal für je 5 Minuten in PBS gewaschen und dann für 2 Stunden mit den an ein Fluorofor gekoppelten Zweitantikörpern in 2 \% FCS in PBS versetzt. Nach erneutem fünfminütigem Spülen mit PBS wurden die Schnitte mittels eines Pinsels

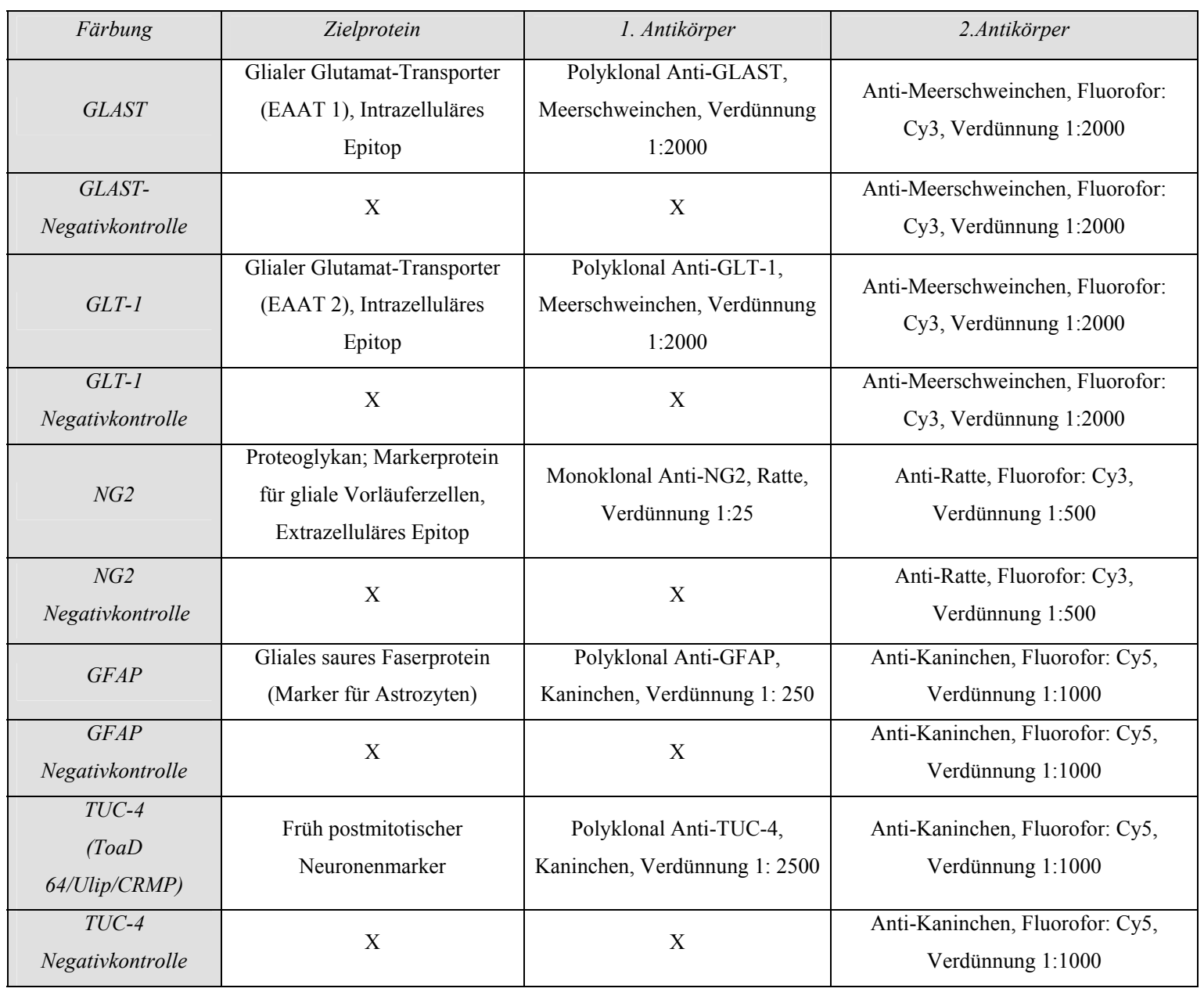

Tab. 3: Für immunohistochemische Experimente verwendete Antikörper

in $\mathrm{H}_{2} \mathrm{O}$ auf Objektträger aufgebracht, luftgetrocknet und mit dem polymerisierenden Kunststoff AquaPoly/Mount (Polysciences, Warrington, PA, USA) unter einem Deckglas fixiert. Die Erstantikörper gegen GLT-1, GLAST und TUC-4 sowie sämtliche Zweitantikörper stammen von der Firma Chemicon International (Temecula, CA, USA). Der Antikörper gegen GFAP stammte von Dako Cytomation (Glostrup, Dänemark), der Antikörper gegen NG2 wurde mir von Professor Dr. Jacqueline Trotter (Institut für molekulare Zellbiologie, Mainz) zu Verfügung gestellt. 


\subsubsection{Färbung einzelner Zellen durch Farbstoffinjektion}

Um die Morphologie identifizierter Zellen sowie deren Kopplung mit anderen Zellen über Gapjunctions nach Identifikation ihrer elektrophysiologischen Eigenschaften beurteilen zu können, wurden Astrozyten während einer Whole-Cell-Voltage-Clamp-Messung mit einem in der PatchPipette befindlichen Farbstoff (Alexa Fluor 568 Hydrazid, Molecular Probes, Eugene, Oregon, USA) gefüllt. Nach 5 bis 10 Minuten wurde die Pipette vorsichtig vom Soma abgelöst. Der Gewebeschnitt wurde anschließend für 2 Stunden in $4 \%$ PFA fixiert. Später wurde die farbstoffgefüllte Zelle und das umliegende Gewebe mit Hilfe eines konfokalen LaserscanningMikroskops (s.u.) untersucht.

\subsubsection{Konfokale Laserscanning-Mikroskopie}

Ein konfokales Laserscanning-Mikroskop (cLSM; LSM 510, Zeiss, Oberkochen) kann mit Hilfe eines Laserstrahls einer bestimmten Wellenlänge ein Fluorofor (z.B. das von den TgN(hGFAPEGFP)-Mäusen in Astrozyten exprimierte EGFP, die antikörpergekoppelten Cy3 oder Cy5, Farbstoffe zur Füllung einzelner Zellen (Cascade Blue, Alexa Fluor 568)) anregen, welches dann Photonen einer anderen Wellenlänge emittiert, die nach Filterung durch Bandpass, Kurzpass und/oder Langpassfilter von Photodioden detektiert und mit Hilfe eines Computers dargestellt werden können. Ein cLSM fokussiert den Laser durch eine Sammellinse auf ein kleines Volumen im Objekt und misst die Intensität der von diesem Volumen emittierten Fluoreszenz. Durch sukzessive Abtastung der aufeinanderfolgenden Punkte einer Fokusebene lässt sich eine zweidimensionale Darstellung der Fluoreszenz dieser Ebene gewinnen. Bei dieser Technik sind die Streueffekte geringer und emittiertes Licht des darüber und darunter liegenden Gewebes verfälscht weniger als bei herkömmlicher Durchlicht- oder Auflicht-Mikroskopie das Bild. Aus den einzelnen XYZ-Koordinaten lassen sich im Computer dreidimensionale Abbildungen des Objekts rekonstruieren. 
In Präparaten, in denen sich mehrere unterschiedliche Fluoreszenzfarbstoffe befinden, lassen sich diese Farbstoffe durch unterschiedliche Anregungs- und Emissionsspektren getrennt voneinander darstellen. Können zwei oder mehrere Fluoreszenzsignale durch sukzessive Anregung innerhalb eines Voxels (Bildpunkt mit XYZ-Koordinate) nachgewiesen werden, spricht man von einer KoLokalisation.

Die Ko-Lokalisation eines Cy3 gekoppelten Antikörpers in einer immunhistochemischen Färbung gegen ein intrazelluläres Epitop und eines EGFP-Moleküls in einem Astrozyten würde sich in einer rechnerischen Addition der roten und grünen Fluoreszenz als ein gelbes Voxel darstellen. Findet man also in einer Schnittebene mit einer räumlichen Auflösung von wie teilweise verwendet 0.14 $\mu \mathrm{m} \times 0.14 \mu \mathrm{m} \times 0.41 \mu \mathrm{m}$ oder in einer dreidimensionalen Darstellung gelbe Voxels, spricht dies z. B. für das Vorhandensein des Ziel-Epitops in einem EGFP-exprimierenden Astrozyten.

Will man ein größeres dreidimensionales Gebilde wie eine Zelle mit all ihren Fortsätzen als zweidimensionales Bild darstellen, lassen sich aus mehreren Schnittbildern Projektionen erzeugen, die jeweils nur die Punkte mit der maximalen Intensität auf einer Achse abbilden. Anhand einer solchen Maximal-Intensitäts-Projektion lassen sich ganze Zellen auf eine Ebene projizieren, indem nur der Punkt mit der stärksten Fluoreszenzintensität in einer Achse dargestellt wird.

Zur Darstellung der grün fluoreszierenden Astrozyten, der immunhistochemisch gefärbten Hirnstammpräparate und farbstoffbeladener Zellen wurden diese mit einem konfokalen Laserscanning-Mikroskop mit 5x, 20x, und 40x Objektiven (Achroplan IR, Zeiss, Oberkochen) untersucht. EGFP wurde bei $488 \mathrm{~nm}$ Wellenlänge mit einem Argon-Laser (Zeiss, Oberkochen) angeregt und das emittierte Signal bandpassgefiltert (500-550 nm) detektiert. Die rote Fluoreszenz von Cy3 und Alexa Fluor 568 wurde bei $543 \mathrm{~nm}$ mit einem Helium-Neon-Laser (Zeiss, Oberkochen) angeregt und langpassgefiltert (560 nm) detektiert. Cy5 wurde bei $633 \mathrm{~nm}$ mit einem Helium-Neon-Laser (Zeiss, Oberkochen) angeregt und mit einem $650 \mathrm{~nm}$ Langpassfilter detektiert. Mit der Software Zeiss LSM 510 sowie dem LSM Image Browser V3.2 (Zeiss, Oberkochen) wurden sämtliche Bilder gespeichert und später offline analysiert und prozessiert. 
Um Bilder in größerer Gewebetiefe mit guter Qualität aufnehmen zu können (für Zellzählungen wurden Aufnahmen eines Gewebeblockes von $50 \mu \mathrm{m}$ Tiefe durchgeführt), wurde ein 2-PhotonenLaserscanning-Mikroskop (2P-LSM; Mikroskop: Axoscope FS2mot, LSM510 NLO, Zeiss, Oberkochen; Laser: 5 Watt VERDI pump Laser, MIRA Titan/Saphir Infrarot-Laser (Coherent, Dieburg); EGFP wurde angeregt mit $840 \mathrm{~nm}$ Wellenlänge) verwendet. Dabei wird das Fluorofor im Gewebe anstatt mit einem Photon einer bestimmten Wellenlänge mit 2 Photonen der doppelten Wellenlänge angeregt. Dabei reicht ein Photon nicht aus, um auch in den über- und unter dem Focus liegenden Gewebeschichten Fluorofor-Moleküle anzuregen. Nur das fokussierte Zielvolumen wird von zwei Photonen erreicht und das dort befindliche Fluorofor ist somit die einzige Quelle für Fluoreszenz im Gewebe. So können in größerer Gewebetiefe Bilder mit guter Qualität aufgezeichnet werden, außerdem treten weniger Bleich-Effekte auf.

\subsubsection{Zählungen von Astrozyten im Hirnstammgewebe}

Das Verhältnis von Astrozyten mit unterschiedlicher Fluoreszenzintensität in der VRG und im Ncl. n. hypoglossi wurde durch manuelles Auszählen von der Zellen ermittelt. Dazu wurden mit einem 2P-LSM Gewebeblöcke mit den Abmessungen von $150 \mu \mathrm{m}$ x $150 \mu \mathrm{m}$ x $50 \mu \mathrm{m}$ gescannt und die Bilderstapel Ebene für Ebene begutachtet. Dabei wurden die Astrozyten von zwei Personen in Zellen mit starker und schwacher Fluoreszenzintensität eingeteilt und gezählt.

NG2-positive Zellen wurden in NG2-Immunfluoreszenz-gefärbtem Hirnstammgewebe von TgN(hGFAP-EGFP)-Mäusen im Alter von 2 und 23 Tagen ausgezählt. Dazu wurden cLSM-Bilder einer Fokusebene mit den Maßen $150 \mu \mathrm{m}$ x $150 \mu \mathrm{m}$ analysiert. 


\subsection{Nachweis von mRNA durch Einzelzell-Reverse- Transkriptase-Polymerase-Kettenreaktion (Einzellzell-RT- PCR)}

\subsubsection{Gewinnung von mRNA}

Mit Hilfe der Einzelzell-RT-PCR lässt sich die Expression eines Proteins in einer bestimmten Zelle auf mRNA-Ebene nachweisen.

Dazu gewinnt man Zytoplasma aus einer Zelle, welche in der Whole-Cell-Konfiguration geklemmt wurde. Nun kann man an der darin vorhandenen mRNA mit Hilfe des Enzyms Reverse Transkriptase cDNA erstellen lassen, sie mit spezifischen Primern (DNA-Fragmente, die sich an bestimmte vorhandene cDNA anlagern) in einer Polymerase-Kettenreaktion (PCR) amplifizieren
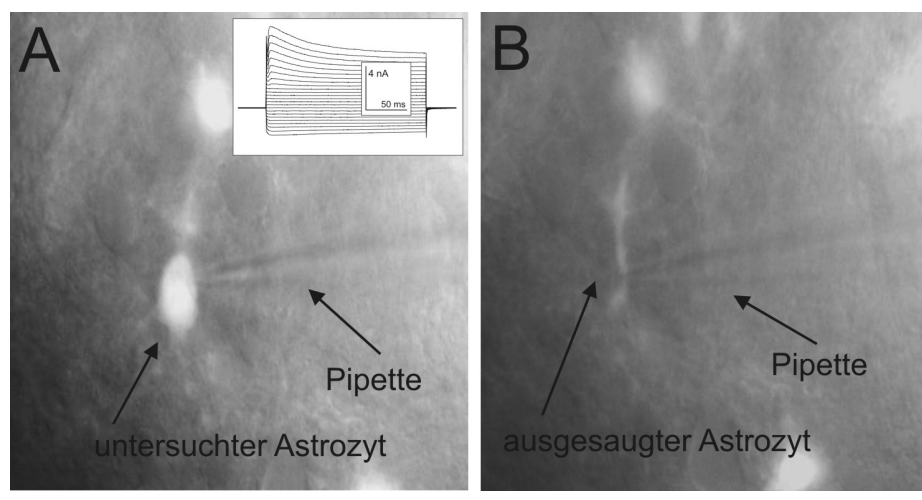

Abb. 7: Gewinnung von mRNA für eine Einzelzell-RT-PCR durch Aussaugen von einzelnen Zellen. A: CCD-Kamera-Bild eines Astrozyten während eines Whole-Cell-Voltage-Clamp-Experiments (Kasten in A: Abgeleitetes IV-Protokoll) B: Astrozyt nach Aussaugen des Zytoplasmas in die Pipette. lassen und per Gel-Elektrophorese nachweisen. So lässt sich die Transskription und damit der erste Schritt der Expression bestimmter Proteine (Rezeptoren, Transporter usw.) in einzelnen Zellen nachweisen.

Zur Gewinnung der mRNA wurden grün fluoreszierende Astrozyten in

der Whole-Cell-Konfiguration untersucht, ein Strom-Spannungsprotokoll der Zellen angefertigt, um Aussagen über die elektrophysiologischen Eigenschaften der Zellen treffen zu können und anschließend deren Zytoplasma mit leichtem Unterdruck in die vorher autoklavierte Patch-Pipette gesaugt (Abb. 7). 


\subsubsection{Reverse-Transkriptions-PCR}

Die reverse Transkription sowie die PCR inklusive der Analyse per Gel-Elektrophorese wurden von Dr. Johannes Hirrlinger (Max-Planck Institut für experimentelle Medizin, Göttingen) durchgeführt. Der prinzipielle Ablauf dieser Versuchsteile war wie folgt:

Die reverse Transkription (RT) fand für 1 Stunde bei $42^{\circ} \mathrm{C}$ in einem Flüssigkeitsvolumen von 10 $\mu 1$, bestehend aus RT-Puffer (Invitrogen, Karlsruhe), Dithiothreitol (Invitrogen; $10 \mathrm{mM}$ ), dNTPs (Roche, Mannheim; jeweils $100 \mu \mathrm{M}$ ), Nonanukleotid Primern (Max-Planck-Institut für Experimentelle Medizin; $5 \mu \mathrm{M}$ ), $20 \mathrm{U}$ RNAsin (Promega, Mannheim) und $100 \mathrm{U}$ Superscript reverse Transkriptase (Invitrogen, Karlsruhe).

Um die cDNAs für GLT-1, GLAST, die AMPA Rezeptoren 1-4 (R1-R4) und $\beta$-Aktin zu amplifizieren, wurde eine 2-Runden-Multiplex-PCR durchgeführt. Die Sequenzen der Primer wurden der Veröffentlichung Matthias et al. (2003) entnommen und in der DNA-core-facility des Max-Planck-Institutes für Experimentelle Medizin, Göttingen synthetisiert. Die PCR-Bedingungen sind mit einigen Modifikationen denen aus Matthias et al. (2003) vergleichbar.

Nach Zugabe des PCR-Puffers (Sigma, Taufkirchen), $\mathrm{MgCl}_{2}$ (Quiagen, Hilden; $2.5 \mathrm{mM}$ ), den Primern (jeweils $200 \mathrm{nM}$ ), dNTPs (Roche; $200 \mu \mathrm{M}$ ) und 2.5 U RedTaq Polymerase (Sigma) zum RT-Produkt (resultierendes Flüssigkeitsvolumen $50 \mu$ ) wurde die erste PCR durchgeführt. Nach der initialen Denaturierung $\left(2\right.$ min bei $94^{\circ} \mathrm{C}$ ) wurden 45 Zyklen durchlaufen (Denaturierung bei $94^{\circ} \mathrm{C}$ für 25 Sekunden; Annealing bei $49^{\circ} \mathrm{C}, 2$ min während der ersten fünf Zyklen, 45 Sekunden während der restlichen Zyklen; Extension at $72^{\circ} \mathrm{C}, 25 \mathrm{sec}$; Finale Elongation bei $\left.72^{\circ} \mathrm{C}, 7 \mathrm{~min}\right) .3 \mu \mathrm{l}$ des PCR-Reaktionsproduktes wurden als Vorlage für die zweite PCR benutzt (2 min AnnealingZeit während der ersten 5 Zyklen, 45 Sekunden während der verbleibenden 30 Zyklen. Die Annealing-Temperaturen für "nested" Primer lagen bei $43^{\circ} \mathrm{C}(\mathrm{R} 2), 51^{\circ} \mathrm{C}(\mathrm{R} 1, \mathrm{R} 4), 54^{\circ} \mathrm{C}(\mathrm{GLT} 1$, GLAST, $\beta$-Aktin) und $57^{\circ} \mathrm{C}$ (R3). Die restlichen Bedingungen der zweiten Runde waren die gleichen wie in der ersten Runde, mit Ausnahme der $\mathrm{MgCl}_{2}$-Konzentration, die in den GLT-1-, GLAST-, and $\beta$-Aktin-PCRs 1,5 mM betrug. Die PCR-Produkte wurden mit Hilfe einer Gel- 
Elektrophorese analysiert. Als Positiv-Kontrolle wurden PCRs mit 10 pg Maushirn-RNA als Vorlage durchgeführt. Weglassen der reversen Transkriptase oder die Durchführung der RT-PCR mit Badlösung wurden als Negativ-Kontrollen verwendet. Hierbei konnten keine Amplifikationsprodukte gefunden werden.

\subsection{Datenanalyse, Statistik und Datenverarbeitung}

Für die Durchführung von Spannungsprotokollen und die Applikation von Substanzen bei WholeCell-Voltage-Clamp-Experimenten sowie zur Aufnahme und Speicherung der dabei erhobenen Daten wurden die Computerprogramme Pulse 8.53 (HEKA, Lambrecht), Axograph 4.0 sowie Clampex 8.2. (beide Axon Instruments, Inc.; Foster City, CA, USA) genutzt. Die Daten wurden auf einer Festplatte gespeichert und später offline mit dem Programm Igor Pro (Wave Metrics, Lake Oswego, Oregon, USA) analysiert.

Die statistische Auswertung der elektrophysiologischen Daten erfolgte mit dem Programm Sigma Stat 3.1 (SPSS Inc., Chicago, USA). Zur statistischen Überprüfung signifikanter Unterschiede wurden die Daten durch das Programm auf Normalverteilung getestet. Waren die Daten normalverteilt und in zwei Gruppen angeordnet, wurde ein t-test durchgeführt. Bei $\mathrm{p} \leq 0.05$ wurde ein signifikanter Unterschied der beiden Datengruppen angenommen.

Bei Experimenten mit drei Datengruppen wurde ein One-Way-ANOVA(analysis of variance)-Test durchgeführt. Bei nichtnormalverteilten Daten wurde bei signifikanten Unterschieden der Datengruppen $(\mathrm{p} \leq 0.05)$ ein paarweiser Vergleich der Datengruppen nach der „Dunn“-Methode durchgeführt. In Balkendiagrammen wurden die Daten als Mittelwert plusminus ( \pm ) Standardfehler angegeben. Signifikante Unterschiede zwischen zwei Datengruppen wurden als Stern über dem Balkendiagramm dargestellt. 


\section{Ergebnisse}

\subsection{Identifikation von Astrozyten im respiratorischen Netzwerk}

In Hirnstamm-Präparaten aus den TgN(hGFAP-EGFP)-Mäusen wurden Astrozyten anhand ihrer grünen Fluoreszenz (Nolte et al. 2001) identifiziert. Die Intensität der Fluoreszenz variierte sowohl in den Zellen der ventralen respiratorischen Gruppe (VRG) als auch im Kerngebiet des Nervus hypoglossus (Ncl. n. XII). Prinzipiell konnte unterschieden werden zwischen Astrozyten mit
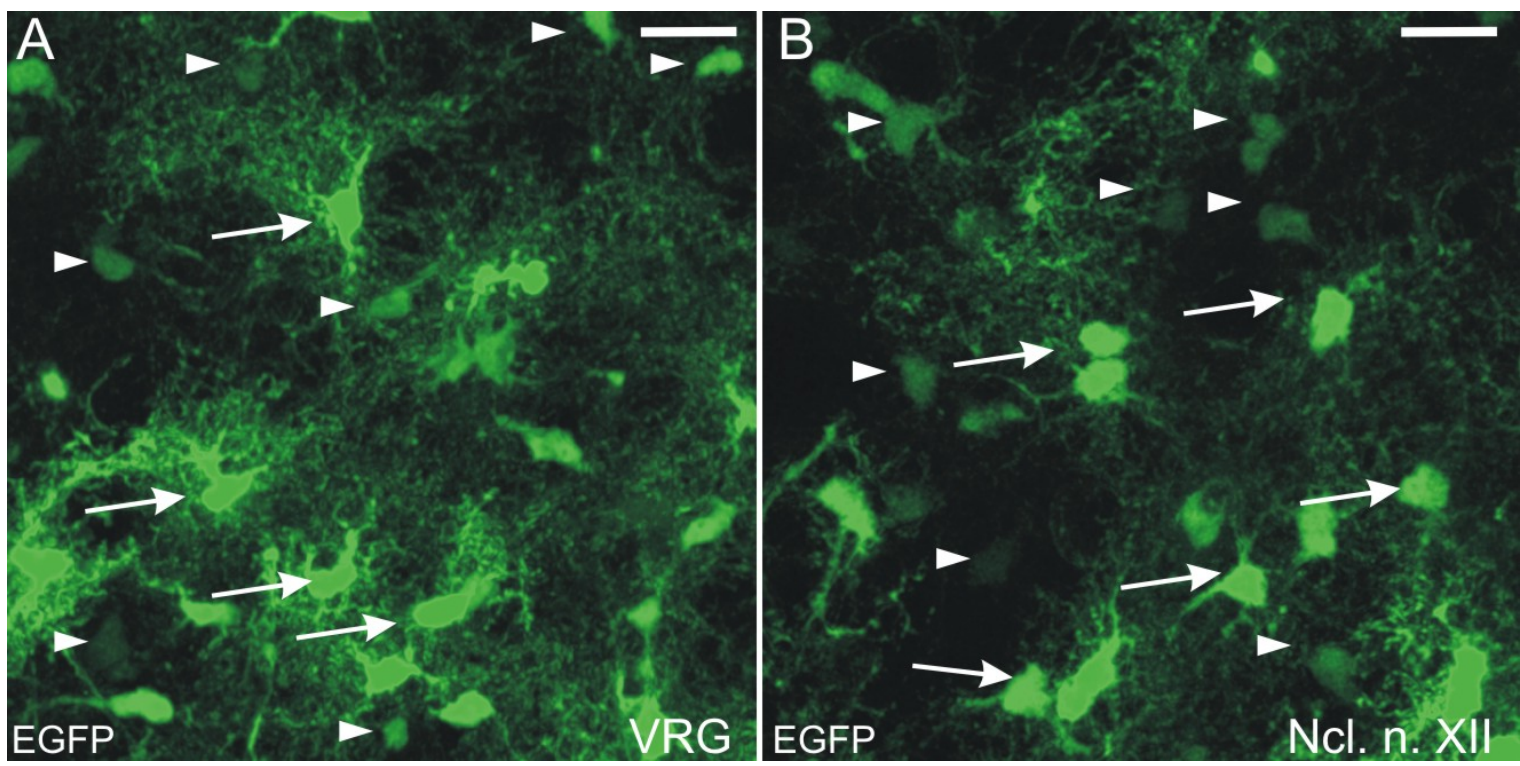

Abb. 8: Unterschiedliche EGFP-Fluoreszenzintensitäten und Morphologie von Astrozyten in verschiedenen Kerngebieten des respiratorischen Netzwerkes. A,B: Maximale-Intensitäts-Projektionen von mittels konfokaler Laserscanning Mikroskopie aufgenommenen Bildern aus der ventralen respiratorischen Gruppe (VRG, A) und dem Kerngebiet des Nervus hypoglossus (Ncl. n. XII, B). In beiden Regionen sind weit und dicht verzweigte stark fluoreszierende Astrozyten (Pfeile) sowie schwach leuchtende, scheinbar weitaus weniger verzweigte Astrozyten (Pfeilspitzen) zu finden. Länge der Messbalken: $20 \mu \mathrm{M}$.

schwacher und starker Fluoreszenz (Abb. 8). Um das Zahlenverhältnis der beiden Typen zu evaluieren, wurden die Zellen in dreidimensionalen Aufnahmen mittels eines 2P-LaserscanningMikroskops von Gewebeblöcken von $150 \mu \mathrm{m}$ x $150 \mu \mathrm{m}$ x $50 \mu \mathrm{m}(\mathrm{n}=4)$ gezählt. Dabei konnte in der VRG eine annähernd ausgeglichene Anzahl an stark fluoreszierenden $(46,7 \pm 4,0 \%)$ und schwach fluoreszierenden Zellen (53,3 \pm 4,0 \%) gezählt werden. Im Bereich des Ncl n. hypoglossi wurde ebenfalls ein ausgeglichenes Verhältnis von 53,8 \% (hell fluoreszierend) zu 46,2 \% (schwach fluoreszierend) gefunden $(\mathrm{n}=1)$. 
Die Astrozyten unterschiedlicher Fluoreszenzintensität wiesen zusätzlich deutliche Unterschiede in
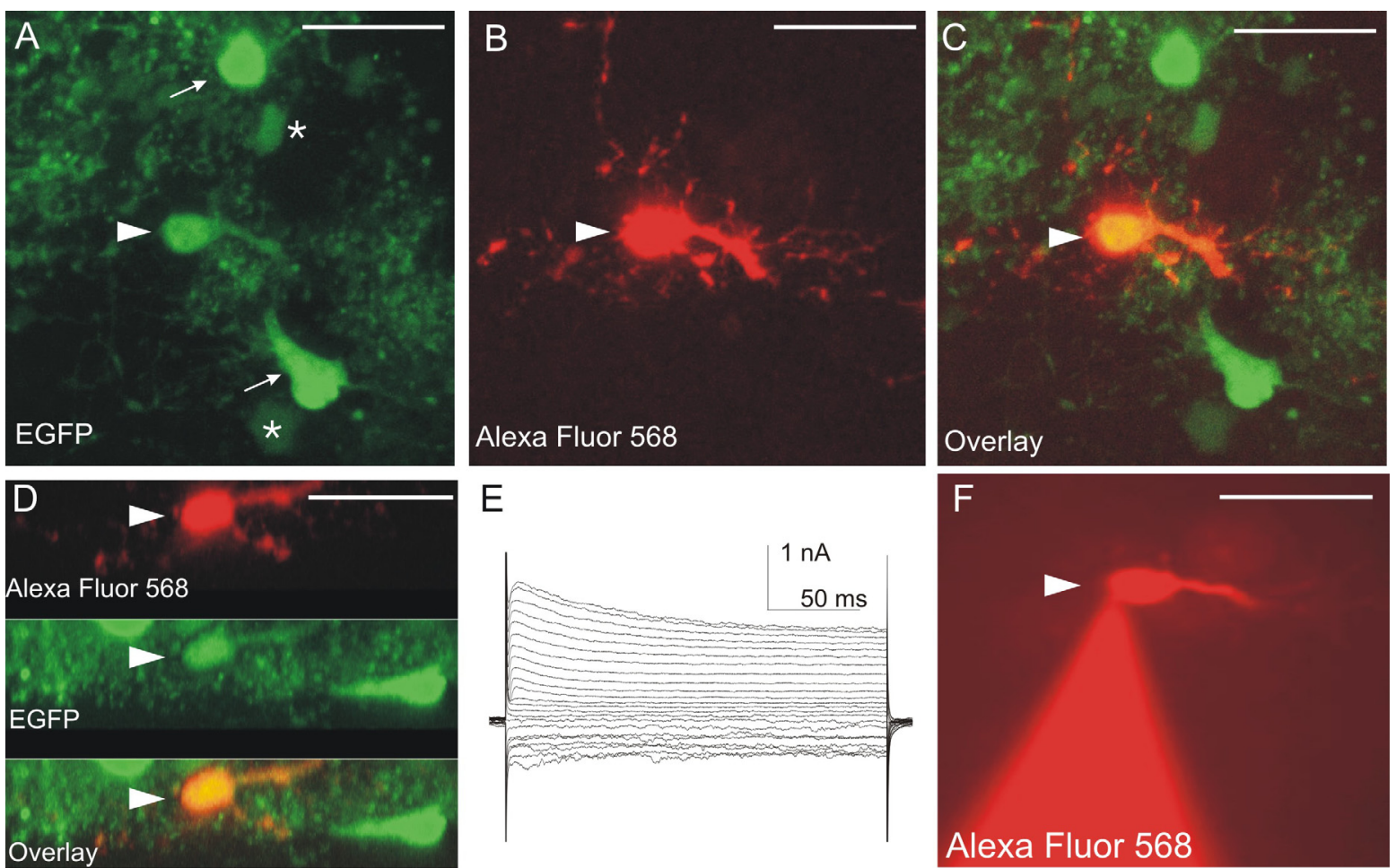

Abb. 9: Morphologie eines schwach EGFP-fluoreszierenden Astrozyten im Ncl. n. hypoglossi. A: cLSM Aufnahme (Maximale-Intensitäts-Aufnahme) der EGFP-Fluoreszenz einer schwach fluoreszierenden Zelle (Pfeilkopf), die während eines Whole-Cell-Voltage-Clamp-Experiments (Strom-Spannungsprotokoll in E) mit dem roten Fluoreszenz-Farbstoff Alexa Fluor 568 gefüllte wurde (B). Sie ist benachbart von zwei schwach fluoreszierenden (Sterne) und zwei stark fluoreszierenden Astrozyten (Pfeile). Die Bilder zeigen die typische weite Verzweigung von in der EGFP-FluoreszenzDarstellung nicht sichtbaren dünnen, mit knötchenartigen Verdickungen versehenen Fortsätzen der schwach fluoreszierenden Zelle. C: Überlagerung aus A und B. D: Rekonstruierte seitlich Maximale-Intensitäts-Projektion der gefüllten Zelle mit Darstellung der grünen EGFP- und der roten Alexa Fluor 568-Fluoreszenz sowie deren Überlagerung (overlay). E: Whole-Cell-Voltage-Clamp-Strom-Spannungsprotokoll der gefüllten Zelle mit 10-mV-200-msSpannungssprüngen auf -150 bis $+50 \mathrm{mV}$ von einem Haltepotential von $-80 \mathrm{mV}$. F: CCD-Kamera-Aufnahme der Alexa Fluor 568-Fluoreszenz während des elektrophysiologischen Experiments mit Darstellung der Farbstoff-gefüllten PatchPipette. Länge der Messbalken: $20 \mu \mathrm{M}$.

ihrer Morphologie auf. Stark fluoreszierende Zellen zeigten sowohl in cLSM- als auch in fluoreszenzmikroskopischen Bildern charakteristischerweise runde oder multipolare Somata und eine großen Anzahl an weit und dicht verzweigten Fortsätzen (Abb. 8). In Zellen mit schwacher Fluoreszenzintensität waren die Fortsätze jedoch nur schwer zu identifizieren. 
Um eine genauere morphologische Analyse einzelner Astrozyten durchzuführen, wurden mehrere stark $(\mathrm{n}=11)$ und schwach $(\mathrm{n}=8)$ fluoreszierende Astrozyten während Whole-Cell-Voltage-ClampExperimenten über die Patch-Pipette mit einem rot fluoreszierenden Farbstoff (Alexa Fluor 568) beladen. Anschließend wurden die gefüllten Zellen mit Hilfe eines cLSMs dargestellt (Abb. 9;10).
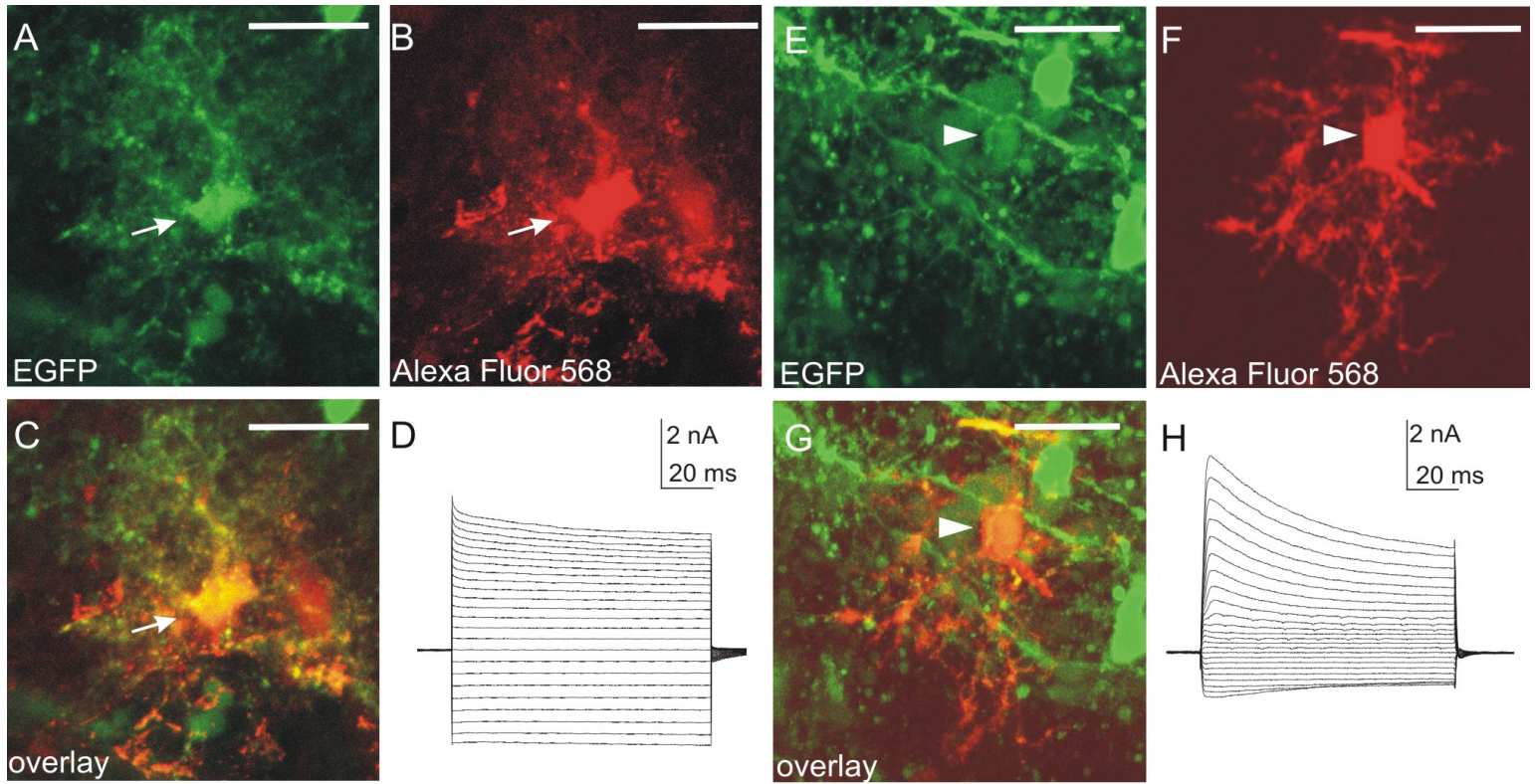

Abb. 10: Zur besseren Darstellung der Morphologie verschiedene mit Farbstoff gefüllte EGFP-exprimierende Astrozyten. Während Whole-Cell-Voltage-Clamp-Experimenten mit einem rot fluoreszierenden Farbstoff (Alexa Fluor 568) gefüllte Astrozyten starker (A-D) und schwacher (E-H) Fluoreszenzintensitäten. A-C: Nach Fixierung des Gewebes durchgeführte Maximale-Intensitäts-Projektion einer cLSM-Aufnahme eines stark fluoreszierenden Astrozyten. Man erkennt eine dichte und stark verzweigte Fortsatz-Struktur mit einer Ausdehnung von mehr als $20 \mu \mathrm{M}$ in jede Richtung. D: Membranströme dieses Astrozyten, gemessen während Spannungssprüngen auf -150 bis $+70 \mathrm{mV}$ (100ms Dauer). E-G: Ein mit Alexa Fluor 568 gefüllter schwach fluoreszierender Astrozyt zeigt einen weniger dichten und weniger stark verzweigten, in seiner Ausdehnung jedoch dem stark fluoreszierenden Astrozyten vergleichbaren Fortsatz-Baum. Die Fortsätze zeigen knotige Verdickungen. H: Membranströme des in E-G dargestellten schwach fluoreszierenden Astrozyten während der oben beschriebenen Spannungssprünge. Länge der Messbalken: $20 \mu \mathrm{M}$.

Die Zellfortsätze erreichten in allen Zelltypen eine Länge von ca. $20 \mu \mathrm{m}$ in alle Richtungen. Die

Fortsätze der schwach fluoreszierenden Zellen waren jedoch weniger zahlreich und dicht verzweigt, als die der stark fluoreszierenden Zellen. An den Verzweigungen der Fortsätze schwach fluoreszierender Zellen fanden sich zum Teil knötchenartige Verdickungen, die in stark fluoreszierenden Zellen nicht nachgewiesen werden konnten. 


\subsection{Elektrophysiologische Untersuchungen an Astrozyten}

\subsubsection{Unterschiedliche Strom-Spannungs-Charakteristika in Astrozyten}

Um die Membranströme sowie die Strom-Spannungs-Relationen der Astrozyten zu messen, wurden die Zellen in Whole-Cell-Voltage-Clamp-Experimenten von einem Haltepotential von -80 $\mathrm{mV}$ auf Membranpotentiale von $-150 \mathrm{mV}$ bis $+50 \mathrm{mV}$ (in 10-mV-Schritten, Dauer 100-200 ms) geklemmt. Dabei wurden die resultierenden Membranströme aufgezeichnet.

Es herrschte eine große Variabilität in den Expressionsmustern verschiedener Ionenkanal-Ströme (Abb. 11). Um eine bessere Übersichtlichkeit zu gewähren, wurden anhand fester Kriterien der so gemessenen $\mathrm{K}^{+}$-Ströme die so untersuchten Astrozyten in drei Gruppen unterteilt (Abb. 12).

\subsubsection{Passive Astrozyten}

Astrozyten mit weitgehend symmetrischen einwärts und auswärts gerichteten $\mathrm{K}^{+}$-Strömen während hyper- und depolarisierender Membranpotentiale zeigten eine sowohl zu Beginn als auch zum Ende des Spannungssprungs lineare Strom-Spannungs-Kurve (Abb. 12). Diese Astrozyten wurden als passiv bezeichnet $(\mathrm{n}=85)$. Das Ruhemembranpotential dieser Zellen lag bei $-84 \pm 0,9 \mathrm{mV}$ und korrespondierte mit dem niedrigen Eingangswiderstand von $31 \pm 3 \mathrm{M} \Omega$. Die mittlere Amplitude des nicht-inaktivierenden Einwärtsstroms bei einem Membranpotential von $-150 \mathrm{mV}$ betrug $-2,8 \pm$ $0.2 \mathrm{nA}$ (Abb. 13;14). Die Einordnung von Astrozyten in die Gruppe der passiven Astrozyten wurde nach folgendem Kriterium vorgenommen: Die Zellen durften neben den passiven Leitfähigkeiten keinerlei auswärts gleichrichtenden Ströme aufweisen. 
A

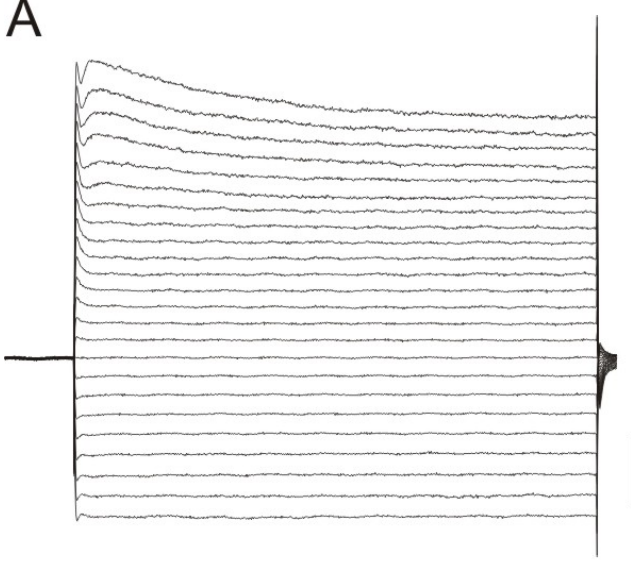

C

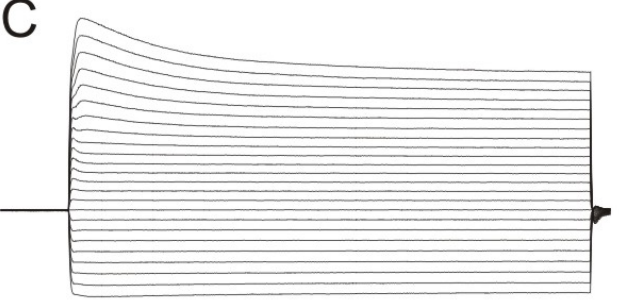

E

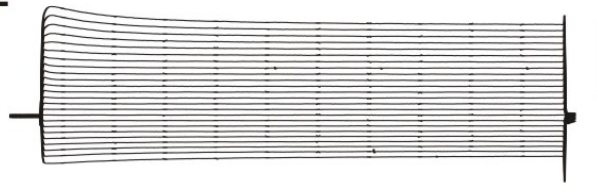

G
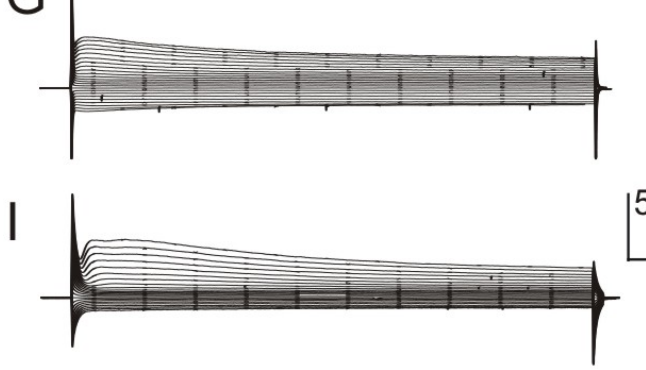

K

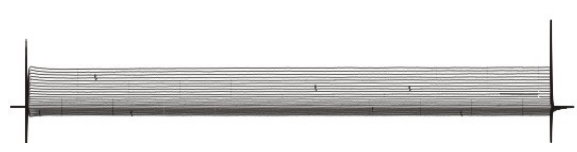

B

$5 \mathrm{nA}$ $50 \mathrm{~ms}$

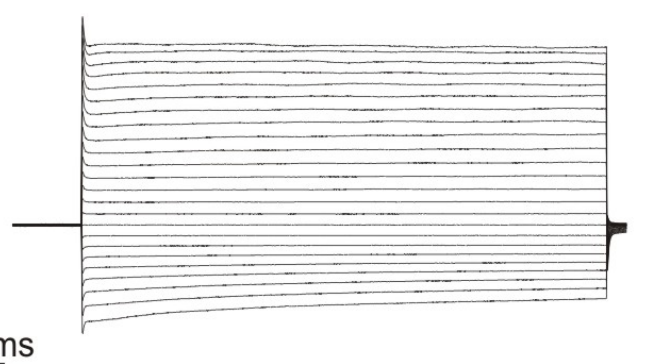

D

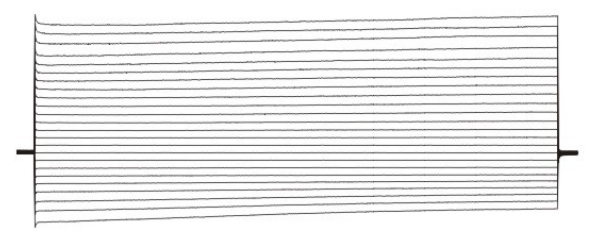

$\mathrm{F}$

$5 \mathrm{nA}$ $50 \mathrm{~ms}$

$\mathrm{H}$

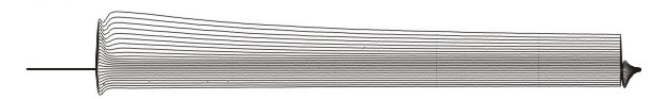

$50 \mathrm{~ms}$

L

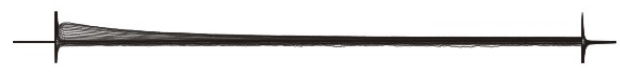

Abb. 11: Astrozyten weisen eine große Variabilität in der Expression verschiedener Ionenkanäle und der Amplitude von Membranströmen auf. A: Große passive Leitfähigkeiten, transienter Auswärtsstrom. B: Große passive Leitfähigkeiten, transienter Einwärtsstrom C: Wie A, jedoch kleinere Amplituden, geringer transienter Einwärtsstrom. E: Große passive Leitfähigkeiten, langsam aktivierender Auswärtsstrom, deaktivierender Einwärtsstrom. E: Geringere passive Leitfähigkeiten, transienter Einwärts- und Auswärtsstrom. F: wie A und B, jedoch deutlich geringere passive Leitfähigkeiten. G: Wie E, jedoch kaum noch passive Leitfähigkeiten. H: Auswärts gleichrichtender Charakter, sowohl transiente als auch nicht inaktivierende Auswärtsströme, kaum noch passive Leitfähigkeiten. I: Wie H, jedoch zweigipfeliger transienter Auswärtsstrom. J: Wie H, jedoch keine passiven Leitfähigkeiten, K: wie J, jedoch ohne transienten Auswärtsstrom. L: Transienter Auswärtsstrom als einzige Membranleitfähigkeit. 
A

B
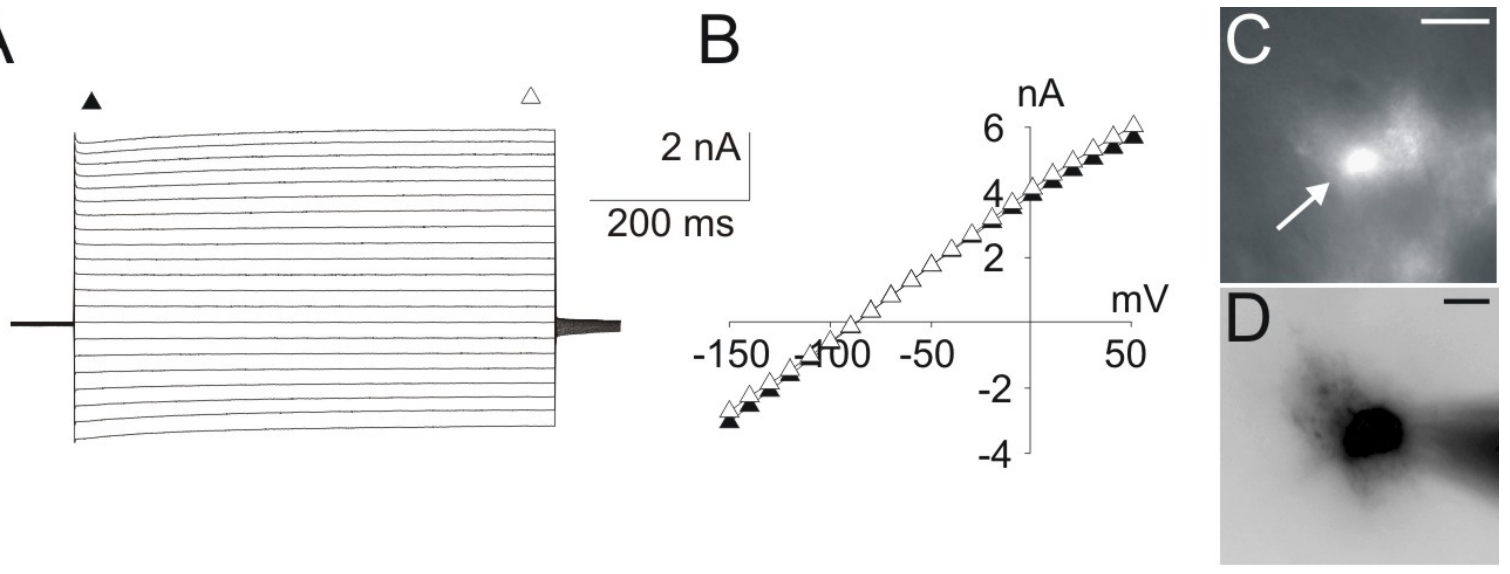

E
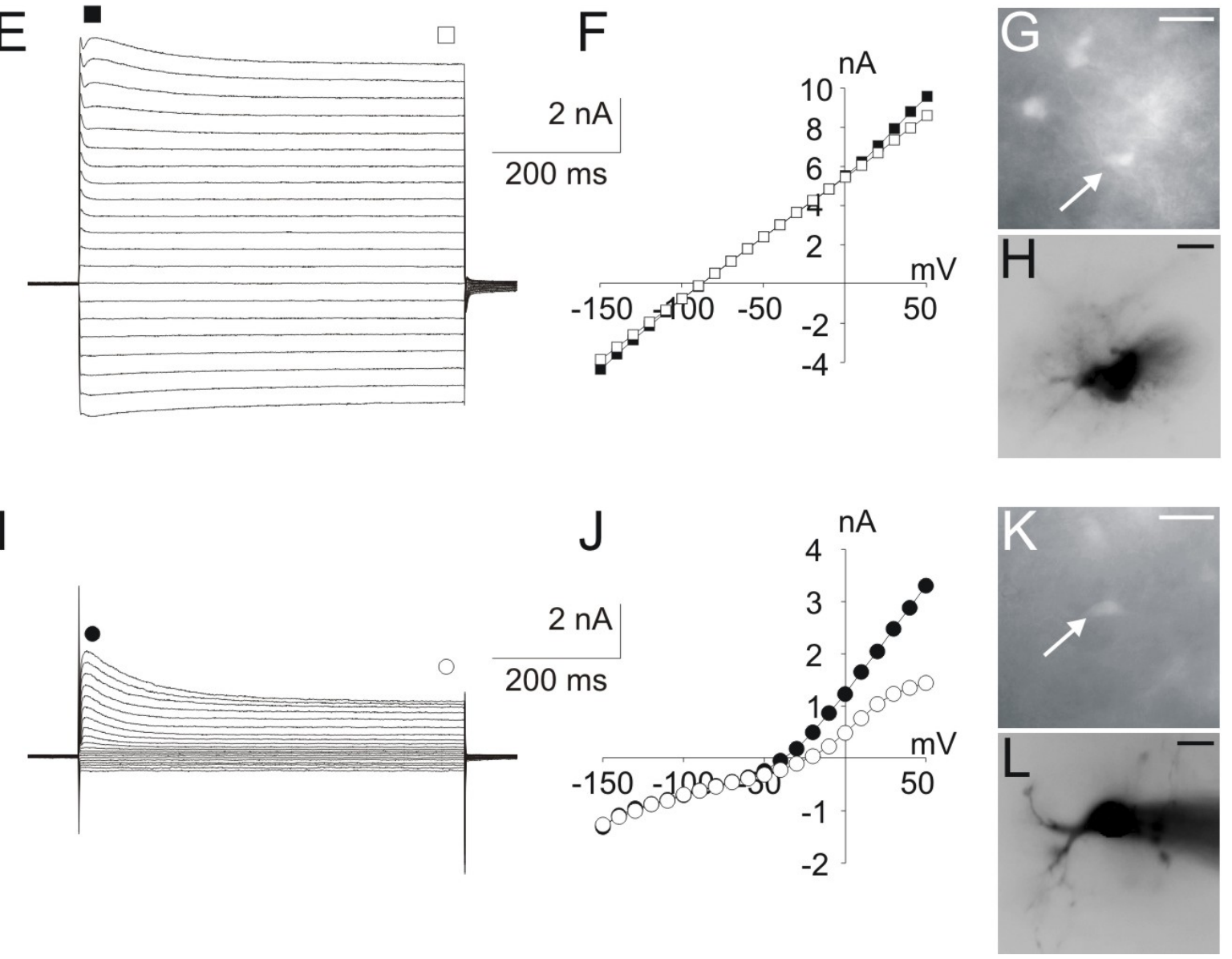

Abb. 12: Unterschiedliche I-V-Kurven von Astrozyten in der ventralen respiratorischen Gruppe (VRG). A-D: WholeCell-Voltage-Clamp-Aufzeichnungen (A), I-V-Kurven und die dazugehörigen Fluoreszenz-Mikroskop-Bilder (CCDKamera-Aufnahmen; C,D) von einem passiven Astrozyten aus der VRG. E-L: Die gleichen Daten von einem intermediären (E-H) und einem auswärts gleichrichtenden (I-L) Astrozyten. Die CCD-Kamera-Bilder in C, G, und K zeigen die EGFP-Fluoreszenz der Zellen, die Bilder in D, H und L stellen den Fluoreszenzfarbstoff Alexa-Fluor 568, der während der Experimente in die Zellen injizierte wurde, dar. Die elektrophysiologischen Aufzeichnungen repräsentieren Strom-Spannungs-Protokolle mit Spannungssprüngen auf -150 bis $+50 \mathrm{mV}$ (10-mV-Schritte) von einem Haltepotential von $-80 \mathrm{mV}$. Für die I-V-Kurven wurden die Amplituden zu Beginn (gefüllte Symbole) und zum Ende (leere Symbole) gemessen und gegen die angelegte Membranspannung aufgetragen. Länge der Messbalken: $20 \mu \mathrm{M}$. 


\subsubsection{Intermediäre Astrozyten}

Astrozyten, die bei Membranpotentialen positiver als $-50 \mathrm{mV}$ einen initialen transienten auswärtsgerichteten Strom, am Ende des Spannungspulses jedoch eine lineare IV-Kurve zeigten, wurden als intermediär bezeichnet ( $\mathrm{n}=64$; Abb. 12). Das durchschnittliche Ruhemembranpotential dieser Zellen lag bei $-84 \pm 1,1 \mathrm{mV}$, der Eingangswiderstand (33 $\pm 3 \mathrm{M} \Omega$ ) sowie der Einwärtsstrom bei $-150 \mathrm{mV}(-2,6 \pm 0,2 \mathrm{nA})$ waren ebenfalls vergleichbar mit den bei passiven Astrozyten gemessenen Werten (Abb. 13;14). Das Kriterium zur Einordnung von Astrozyten in die Gruppe der intermediären Astrozyten war ein neben passiven Leitfähigkeiten auftretender transienter spannungsabhängiger Auswärtsstrom.

\subsubsection{Auswärts gleichrichtende Astrozyten}

Eine dritte Gruppe von Astrozyten unterschied sich durch das Fehlen von Einwärtsströmen sowie durch eine auswärts gleichrichtende Strom-Spannungs-Kurve von den anderen Zelltypen (Abb. 12). Der initiale transiente auswärtsgerichtete Strom zeigte Eigenschaften eines A-Typ $\mathrm{K}^{+}$-Stroms. Weiterhin boten diese Zellen einen zusätzlichen nicht inaktivierenden auswärts gleichrichtenden

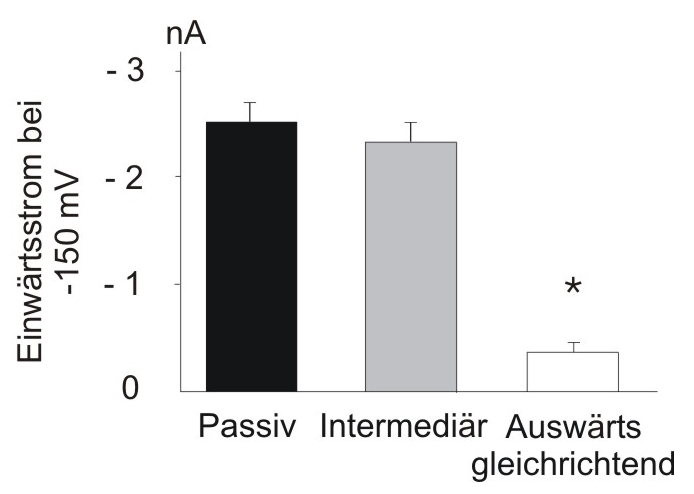

Abb. 13: Maximaler Einwärtsstrom zu Beginn eines Spannungssprungs auf $-150 \mathrm{mV}$ in drei verschiedene Astrozytentypen während Whole-Cell-VoltageClamp-Experimenten, dargestellt als Mittelwert \pm Standardmessfehler, signifikant $(*)$ bei $\mathrm{p}<0.05$, One-Way ANOVA Test, „Dunn“-Methode.
Membranstrom. Das Ruhemembranpotential dieser Zellen war, verglichen mit passiven und intermediären Astrozyten, signifikant (One-Way ANOVA Test, „Dunn“-Methode“) geringer negativ $(-66 \pm 4 \mathrm{mV})$, korrespondierend mit dem signifikant (One-Way ANOVA Test, „Dunn“Methode“) erhöhten Eingangswiderstand (319 \pm $43 \mathrm{M} \Omega$ ). Ebenfalls signifikant (One-Way ANOVA Test, „Dunn“-Methode“) erniedrigt waren die durchschnittlichen Einwärtsströme bei 
einem Membranpotential von $-150 \mathrm{mV}$ (Abb. 13;14). Diese Zellen wurden auswärts gleichrichtende Astrozyten (outwardly rectifying astrocytes; nach Zhou und Kimelberg 2000) genannt.

Das Kriterium zur Unterscheidung von intermediären und auswärts gleichrichtenden Astrozyten war das Auftreten spannungsabhängiger, auswärts gleichrichtender, nicht deaktivierender Ströme in auswärts gleichrichtenden Zellen. Zum Nachweis wurde der Eingangswiderstand bei $-80 \mathrm{mV} /$ $90 \mathrm{mV}$ bestimmt (siehe Methodenteil) und mit dem Eingangswiderstand bei $+30 \mathrm{mV} /+40 \mathrm{mV}$ am
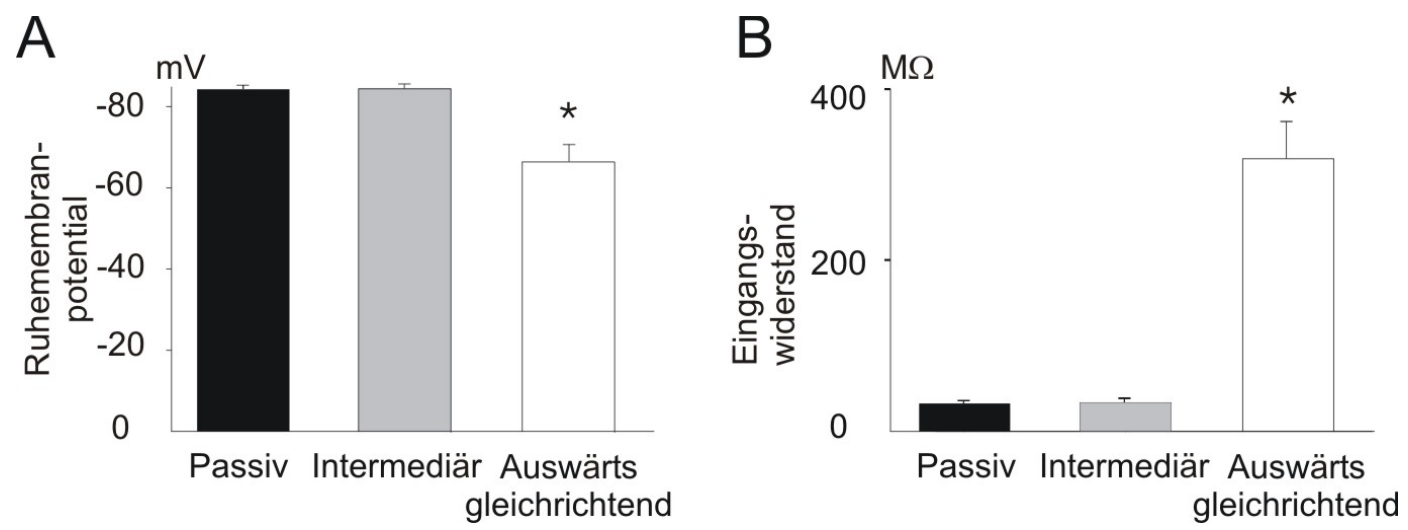

Abb. 14: Elektrophysiologische Eigenschaften der drei unterschiedenen Astrozyten-Typen. Ruhemembranpotential (A) und Eingangswiderstand (B) der drei Zellgruppen, dargestellt als Mittelwert \pm Standardmessfehler, signifikant unterschiedlich gegenüber den anderen Gruppen $(*)$ bei $\mathrm{p}<0.05$; One-Way ANOVA Test, „Dunn“-Methode.

Ende der Spannungssprünge verglichen. Betrug der Eingangswiderstand bei depolarisiertem Membranpotential $(+30 \mathrm{mV} /+40 \mathrm{mV})$ weniger als $80 \%$ des Eingangswiderstands in der Nähe des Haltepotentials $(-80 \mathrm{mV} /-90 \mathrm{mV})$, so konnte auf die Existenz von nicht deaktivierenden spannungsabhängigen Auswärtsströmen geschlossen werden. Damit wurden die Zellen zur Gruppe der auswärts gleichrichtenden Astrozyten gezählt.

\subsubsection{A-Typ- $\mathrm{K}^{+}-$Ströme in Astrozyten}

Transiente Auswärtsströme, besonders der A-Typ- $\mathrm{K}^{+}$-Strom wurden in Astrozyten und glialen Vorläuferzellen in verschiedenen Hirnregionen beschrieben (Jabs et al. 1994, Bordey und Sontheimer 2000, Filippov et al. 2003). 

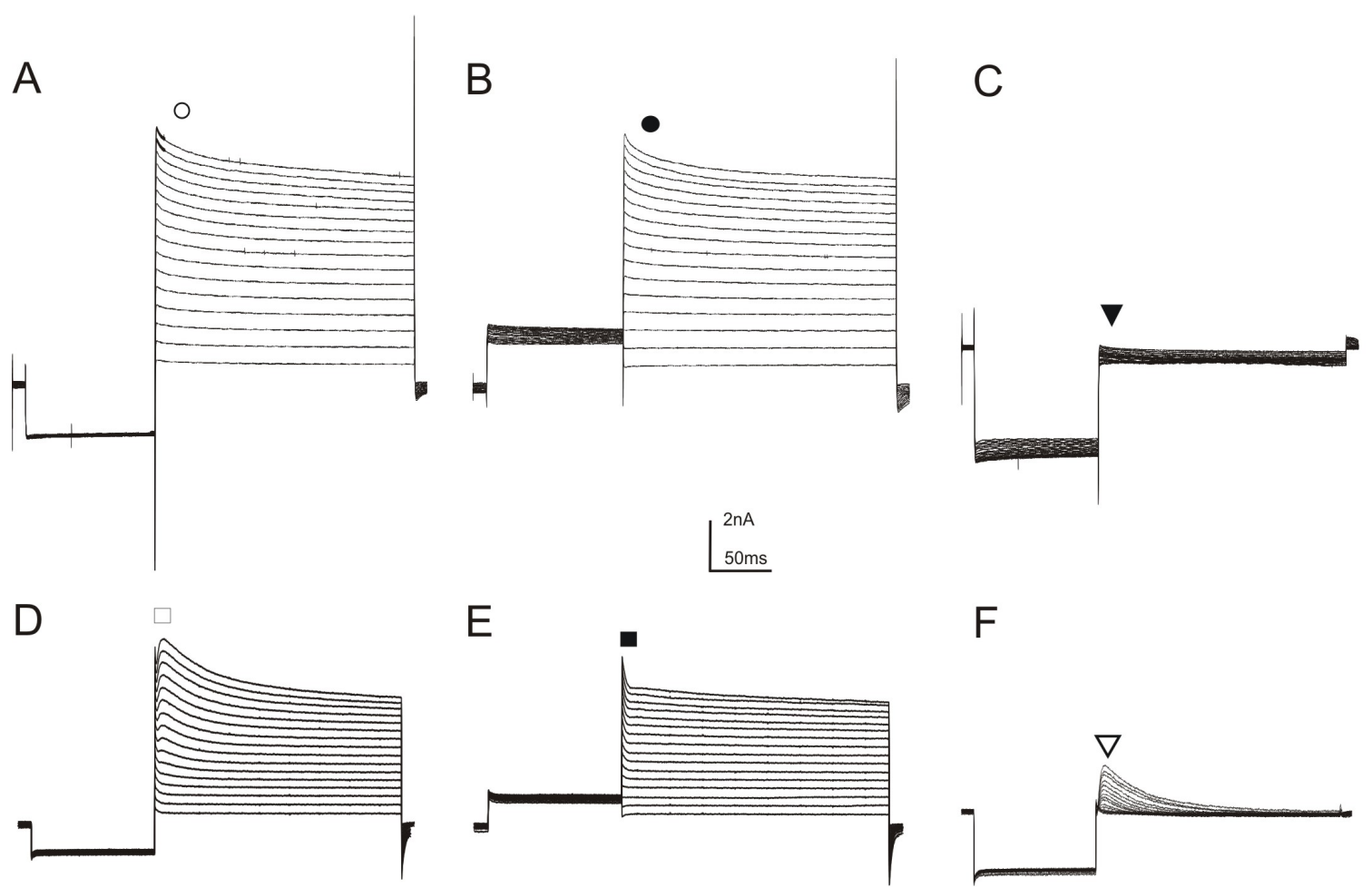

$E$

$\mathrm{F}$

G

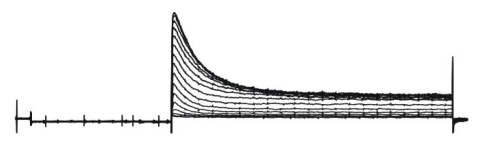

$\mathrm{H}$
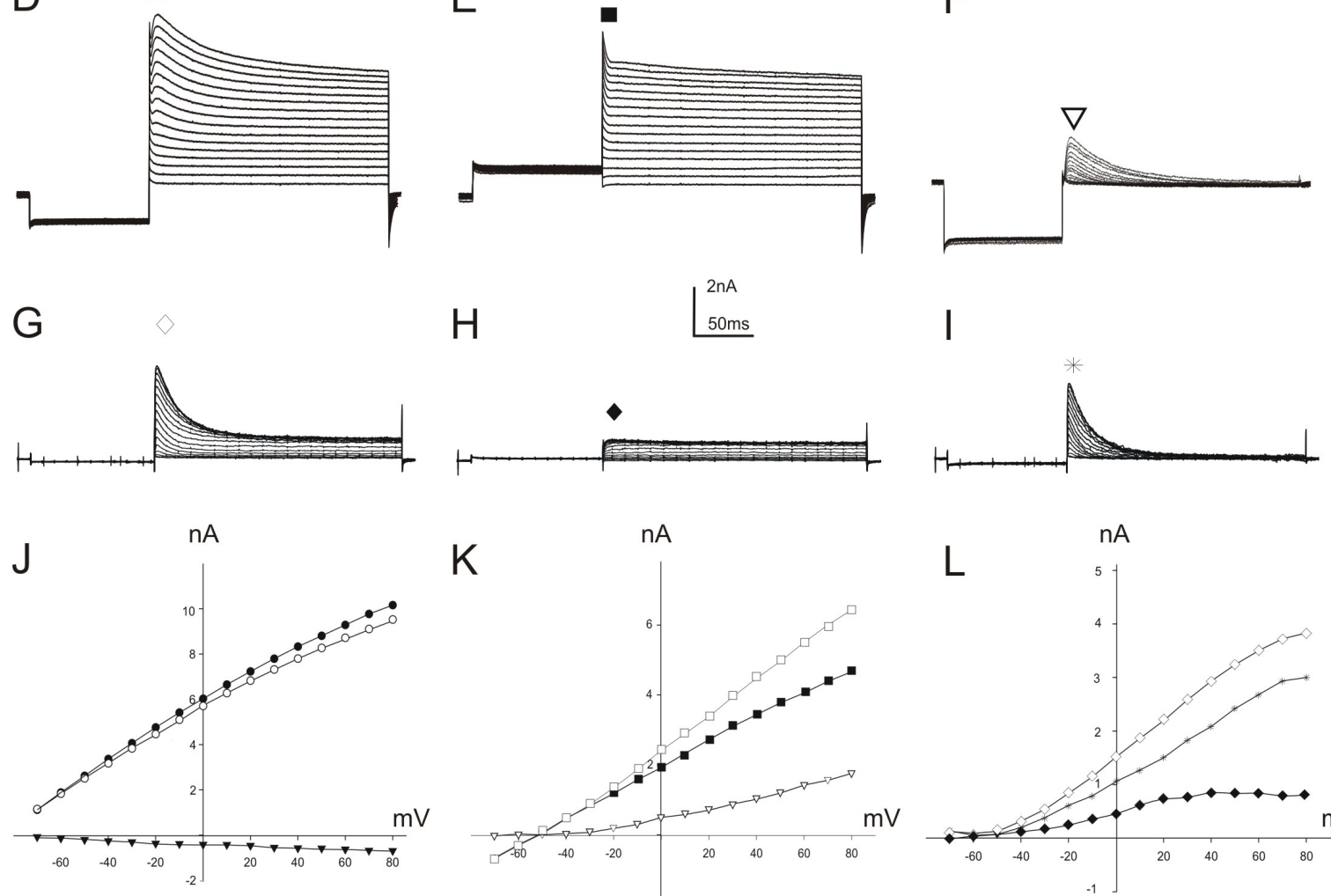

$\mathrm{K}$
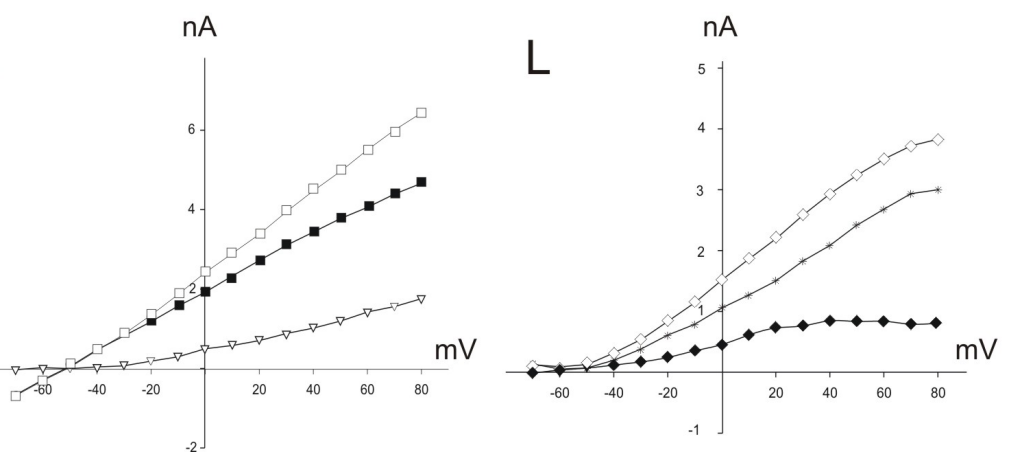

Abb. 15: Expression des A-Typ- $\mathrm{K}^{+}$-Stroms in Astrozyten im respiratorischen Netzwerk. A-I Whole-Cell-VoltageClamp-Aufzeichnungen in einem passiven (A-C), intermediären (D-F) und auswärts gleichrichtenden (G-I) Astrozyten während Spannungssprüngen auf -70 bis $+80 \mathrm{mV}$ für $400 \mathrm{~ms}$ nach vorhergehender Hyperpolarisation auf $-110 \mathrm{mV}(\mathrm{A}, \mathrm{D}$, G) und Depolarisation auf $-50 \mathrm{mV}(\mathrm{B}, \mathrm{E}, \mathrm{H})$ für $100 \mathrm{~ms}$ von einem Haltepotential von $-80 \mathrm{mV}$. Eine Punkt-zu-PunktSubtraktion der Kurven A und B (D und E; G und H) isoliert den transienten auswärts gerichteten A-Typ- $\mathrm{K}^{+}$-Strom. C, F, I: So errechnete A-Typ-K $\mathrm{K}^{+}$-Ströme in den drei Astrozyten-Typen. J-L: Strom-Spannungs-Kurven der in den in A-I dargestellten passiven (J), intermediären $(\mathrm{K})$ und auswärts gleichrichtenden (L) Astrozyten gemessenen Membranströme. Die isolierten A-Typ-Ströme in intermediären (Weiße Dreiecke in K) und auswärts gleichrichtenden (Sterne in L) Astrozyten zeigen eine Aktivierung bei ca. $-40 \mathrm{mV}$. 


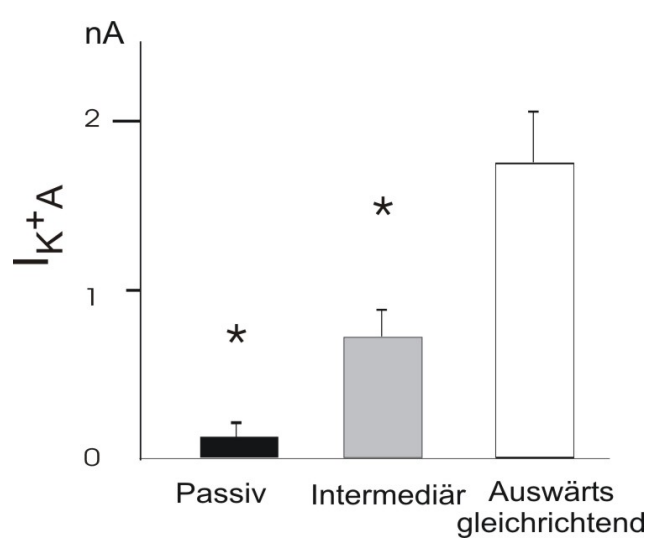

Abb. 16: Mittlere Amplituden der A-Typ- $\mathrm{K}^{+}$-Ströme aus dem Subtraktionsprotokoll (gemessen bei $+70 \mathrm{mV}$ ) in den drei Astrozyten-Typen, Daten als Mittel \pm Standardmessfehler, signifikant unterschiedlich gegenüber den anderen Gruppen $(*)$ bei $p<0.05$, OneWay ANOVA Test, „Dunn“-Methode.
Um den A-Typ- $\mathrm{K}^{+}$-Strom in den Astrozyten quantifizieren zu können, wurde im WholeCell-Voltage-Clamp-Modus ein spezielles Subtraktions-Protokoll mit de- und hyperpolarisierenden Vorpulsen angewendet (siehe Material und Methoden, Abb. 5). Der damit isolierte transiente Auswärtsstrom wurde bei ca. $-40 \mathrm{mV}$ aktiviert und inaktivierte nach ca. 50$80 \mathrm{~ms}$, was den Charakteristika eines A-Typ$\mathrm{K}^{+}$-Stroms entspricht. Die größten Amplituden dieses Stroms bei einem Membranpotential von $+70 \mathrm{mV}$ konnten in auswärts gleichrichtenden Astrozyten gemessen werden $(1,75 \pm 0,31 \mathrm{nA} ; \mathrm{n}=24 ;$ Abb. 15;16).

Der transiente auswärtsgerichtete Strom in diesen Zellen konnte durch $2 \mathrm{mM}$ 4-Aminopyridine (4AP) reversibel um 70,1 7,7 \% ( $\mathrm{n}=3$ ) der Amplitude reduziert werden (Abb. 17). 4-AP ist in dieser Konzentration als Blocker des A-Typ-K ${ }^{+}$-Kanals beschrieben (Bordey und Sontheimer 1999).

A

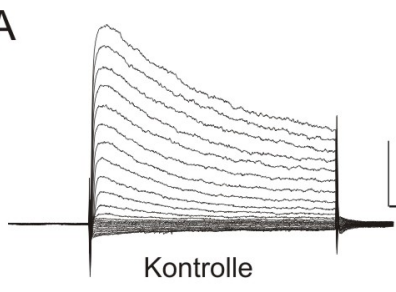

C

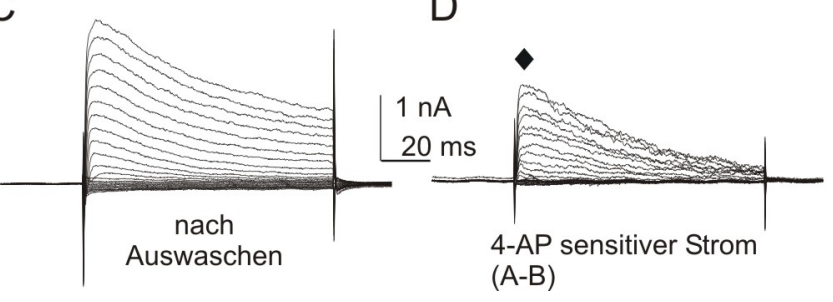

B

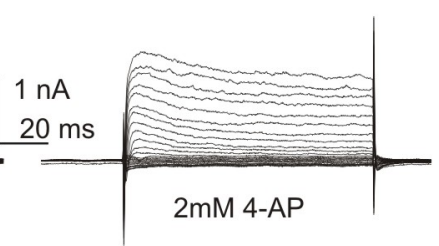

E

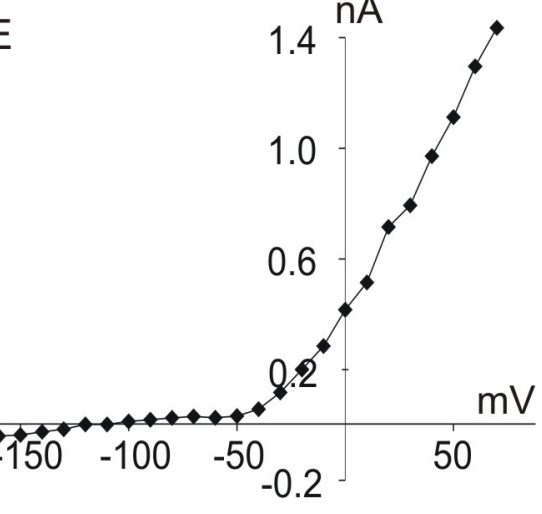

Abb. 17: Blockade des transienten Auswärtsstroms in auswärts gleichrichtenden Astrozyten durch den A-Typ$\mathrm{K}^{+}$-Kanal-Blocker 4-Aminopyridin (4-AP, $\left.2 \mathrm{mM}\right)$. A: Kontroll-Strom-Spannungsprotokoll mit Spannungssprüngen von -170 bis $+70 \mathrm{mV}$ für $100 \mathrm{~ms}$, B: nach Badapplikation von $2 \mathrm{~mm}$ 4-AP, C: 10 Minuten nach Auswaschen von 4-AP D: 4-AP-sensitiver Strom (Subtraktion von A-B). E: Strom-Spannungs-Kurve des 4AP-sensitiven Stroms. Aktivierung des Kanals bei ca. $-50 \mathrm{mV}$. 
Die verbleibende IV-Kurve war vergleichbar mit dem $\mathrm{K}^{+}$-Strom vom delayed-rectifier-Typ (verzögert gleichrichtender Typ). In Astrozyten vom intermediären Typ war der mit Hilfe des VorPuls-Protokolls isolierte Strom kleiner als in auswärts gleichrichtenden Astrozyten (0,72 $\pm 0,17 \mathrm{nA}$; $\mathrm{n}=46 ; \mathrm{p}<0,01)$. In passiven Astrozyten konnte fast kein A-Typ- $\mathrm{K}^{+}$-Strom nachgewiesen werden $(0,13 \pm 0,04 \mathrm{nA} ; \mathrm{n}=55 ; \mathrm{p}<0,001)$. Nach dem One-Way ANOVA Test, „Dunn“-Methode“ war die Amplitude der A-Typ- $\mathrm{K}^{+}$-Ströme in allen drei Zelltypen signifikant unterschiedlich.

\subsubsection{Spannungsabhängige $\mathrm{Na}^{+}-$Kanäle in Astrozyten}

In 11 von 23 auswärts gleichrichtenden Astrozyten konnte ein schneller transienter Einwärtsstrom gemessen werden (Abb. 18). Dieser Strom aktiviert nach ca. 1-2 ms bei einem Membranpotential von ca. $-50 \mathrm{mV}$. Eine Inaktivierung erfolgt nach weiteren 2-3 ms. Diese Werte sind charakteristisch für spannungsabhängige $\mathrm{Na}^{+}$-Kanäle. Wurden Strom-Spannungsprotokolle in der Gegenwart des $\mathrm{Na}^{+}$-Kanal-Blockers Tetrodotoxin (TTX, $500 \mathrm{nM}$ ) aufgezeichnet, fehlte dieser schnelle Einwärtsstrom.

A

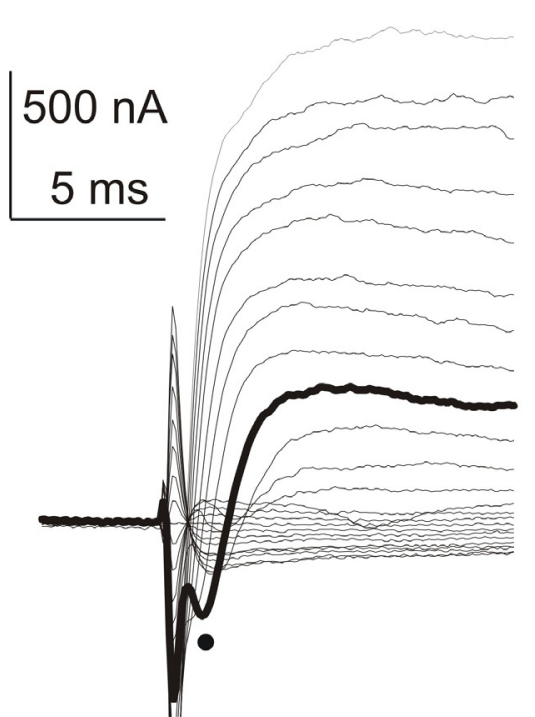

B

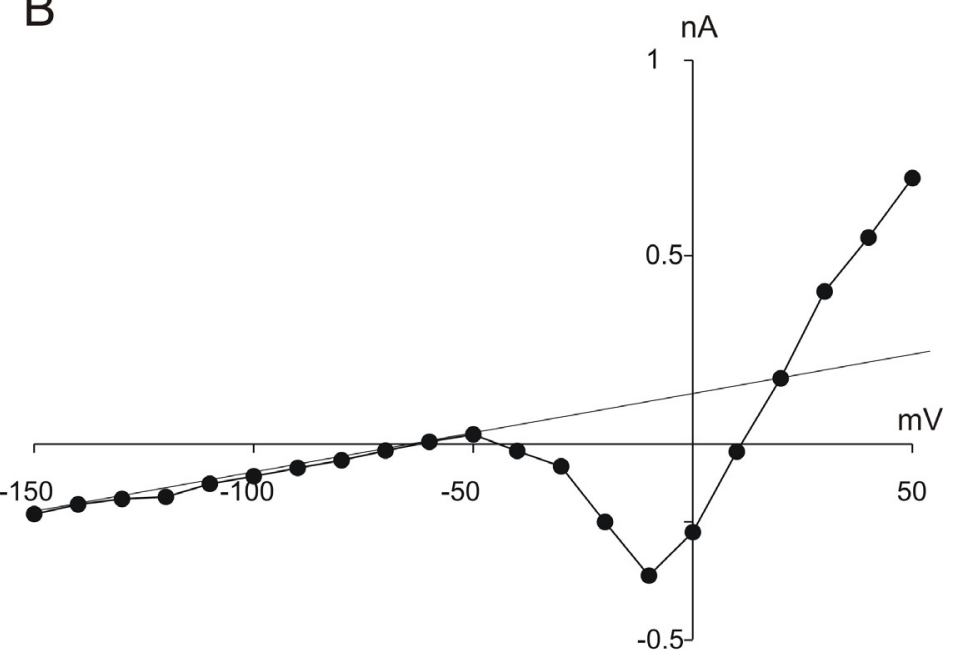

Abb. 18: Schneller spannungsabhängiger Einwärtsstrom in auswärts gleichrichtenden Astrozyten. A: Das StromSpannungsprotokoll mit Spannungssprüngen von -150 bis $+50 \mathrm{mV}$ zeigt einen schnell aktivierenden und nach 2-3 ms inaktivierenden Einwärtsstrom (Strom bei $-10 \mathrm{mV}$ hervorgehoben). B: IV-Kurve mit den nach $2 \mathrm{~ms}$ gemessenen Amplituden aufgetragen gegen die angelegte Spannung. Es zeigt sich ein bei ca. $-50 \mathrm{mV}$ aktivierter Einwärtsstrom. Diese Charakteristika beschreiben einen spannungsgesteuerten $\mathrm{Na}^{+}$-Kanal-Strom. Die gerade Linie in B (Pfeil) zeigt die graphische Interpolation der nicht spannungsabhängigen passiven Leitfähigkeiten. 


\subsection{Korrelation zwischen EGFP-Fluoreszenzintensität und elektrophysiologischen Eigenschaften}

Die Fluoreszenzintensitäten der anhand ihrer Membranströme unterschiedenen Astrozyten wurden während der elektrophysiologischen Messungen mittels einer CCD-Kamera und eines FluoreszenzMikroskops festgehalten.

Von 70 Astrozyten mit starker Fluoreszenz konnten 48 (69\%) der Gruppen der passiven, 21 (30 \%) der intermediären und nur eine Zelle der auswärts gleichrichtende Gruppe von Astrozyten zugerechnet werden. Das bedeutet, eine starke EGFP-Fluoreszenz hat einen hohen prädiktiven Wert für eine große ständige Kaliumleitfähigkeit und daraus resultierend ein negativeres Membranpotential, wie es typisch für passive und intermediäre Astrozyten ist.

Im Gegensatz dazu bot eine schwache EGFP-Fluoreszenz weniger Aussagekraft über den individuellen Zelltypus. Von 72 Zellen mit niedriger Fluoreszenzintensität waren 20 Zellen (28\%) passiv, 25 (34\%) intermediär und 27 Zellen (38\%) zeigten Eigenschaften der auswärts gleichrichtenden Astrozyten.

Mit einer Ausnahme zeigten alle Zellen mit auswärts gleichrichtenden Membranströmen und fehlenden Einwärtsströmen, also fast alle auswärts gleichrichtenden Astrozyten eine schwache EGFP-Fluoreszenz. 


\subsection{Expression von Glutamat-Rezeptoren und Glutamat- Transportern in Astrozyten}

\subsubsection{Unterschiedliche Expression von Glutamat-Transportern in}

\section{Astrozyten}

Glutamat ist im respiratorischen Netzwerk als wichtigster exzitatorischer Transmitter bekannt. Die Aufnahme von Glutamat aus dem Extrazellulärraum durch Astrozyten kann die synaptische Aktivität beeinflussen (Mennerick et al. 1999). Deswegen wurden die Astrozyten auf ihre Reaktionsfähigkeit auf Glutamat untersucht, indem mit verschiedenen Methoden die Expression

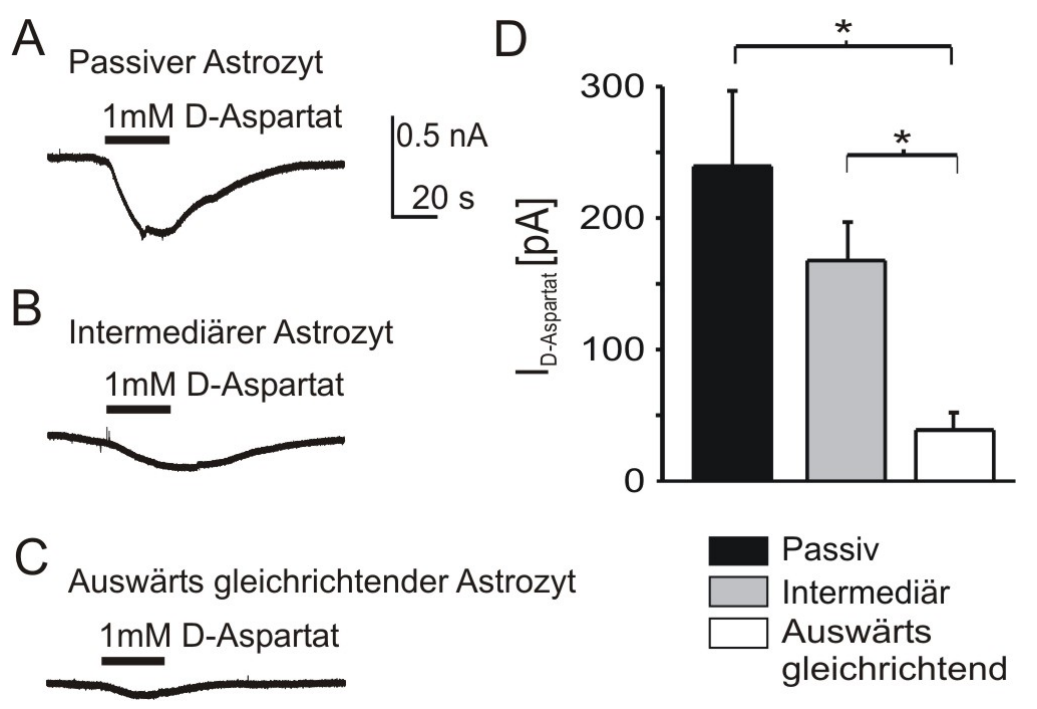

Abb. 19: Expression von Glutamat-Transporter Strömen in verschiedenen Astrozyten-Typen. A-C- Whole-Cell-Voltage-Clamp-Ströme in verschiedenen Astrozyten nach Badapplikation von $1 \mathrm{mM}$ des Glutamat-TransporterAgonisten D-Aspartat. $500 \mathrm{nM}$ TTX, $50 \mu \mathrm{M}$ CNQX und $100 \mu \mathrm{M} \mathrm{CdCl}_{2}$ wurden der Badlösung zur Vermeidung indirekter Effekte zugefügt. D: Mittlere Amplitude des maximal gemessenen D-Aspartat-induzierten Einwärtsstroms in den drei Astrozyten-Gruppen. Daten als Mittel \pm Standardmessfehler, signifikant $(*)$ bei $\mathrm{p}<0.05$, One-Way ANOVA Test, „Dunn“-Methode. von Glutamat-Transportern analysiert wurde. In WholeCell-Voltage-Clamp-Experimenten wurden Membranströme als Antwort auf die Exposition des GlutamatTransporter-Agonisten DAspartat gemessen (Abb. 19). Um dabei jedoch eventuell auftretende indirekte Effekte durch benachbarte Zellen zu vermeiden, wurden der Bad-

lösung Blocker für $\mathrm{Na}^{+}-(500 \mathrm{nM}$ Tetrodotoxin $)$ und $\mathrm{Ca}^{2+}-\mathrm{Kanäle}(100 \mu \mathrm{M} \mathrm{CdCl})$ sowie für Glutamat-Rezeptoren vom AMPA-Typ (50 $\mu \mathrm{M}$ CNQX) zugeführt. Die Zellen wurden bei einem Haltepotential von $-80 \mathrm{mV}$ für 20 Sekunden einer Badlösung, die $1 \mathrm{mM}$ D-Aspartat enthielt, ausgesetzt. Dies führte zu Einwärtsströmen in den untersuchten Astrozyten. 
In passiven Astrozyten wurde ein mittlerer durch D-Aspartat induzierter Strom von $241 \pm 56 \mathrm{pA}$ $(\mathrm{n}=8)$ gemessen. Im Vergleich zu Astrozyten vom intermediären Typ zeigte sich kein signifikanter Unterschied, dort betrug der mittlere Strom $169 \pm 28$ pA (n=12). In auswärts gleichrichtenden Astrozyten konnte nur ein sehr kleiner Einwärtsstrom detektiert werden $(39 \pm 17$ pA; $n=11$; $\mathrm{p}<0.001$ ), dessen Amplitude sich von denen der anderen Zellgruppen signifikant unterschied (One way ANOVA-Test, „Dunn“ Methode).

Um diese Ergebnisse zu verifizieren, wurden an Hirnstammschnitten von TgN(hGFAP-EGFP)Mäusen Immunfluoreszenzfärbungen für die wichtigsten glialen Glutamat-Transporter GLT-1 (EAAT2) und GLAST (EAAT1) durchgeführt (Abb. 20). Im Kerngebieten des respiratorischen Netzwerks wurde eine starke Immunfluoreszenz für beide Transporter auf den Fortsätzen und dem Soma von Astrozyten mit heller EGFP-Fluoreszenz festgestellt. In Astrozyten mit schwacher Fluoreszenz konnte keine GLT-1 oder GLAST assoziierte Fluoreszenz detektiert werden.
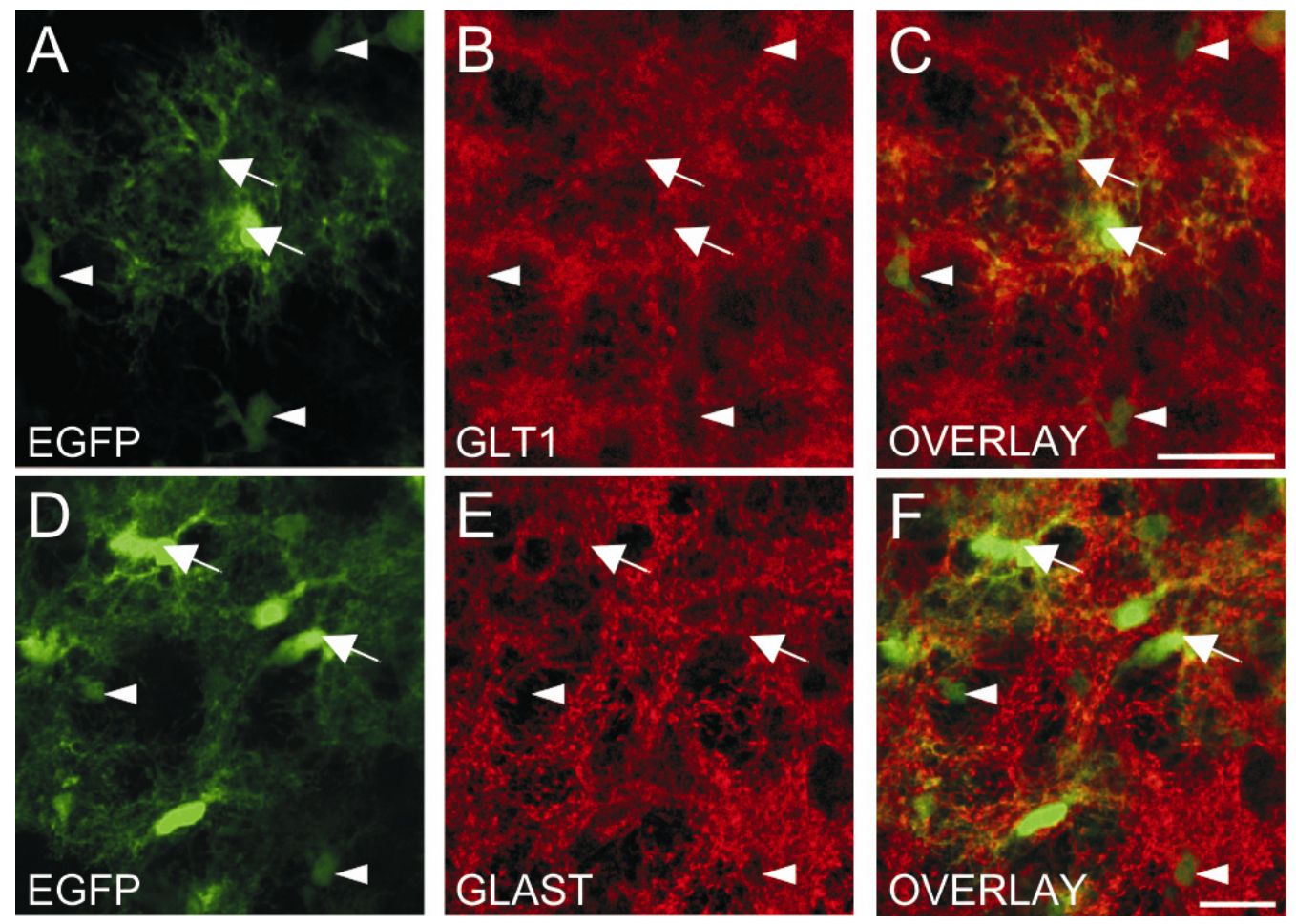

Abb. 20: Immunohistochemische Darstellung der Expression der Glutamat-Transporter GLAST und GLT-1 in Astrozyten. Die Expression der glialen Glutamat-Transporter GLT-1 (A-C) und GLAST (D-F) findet sich nur in Astrozyten mit starker EGFP-Fluoreszenz. In Hirnstammschnitten von 9 Tagen alten Mäusen der TgN(hGFAP-EGFP)-Linie zeigte sich eine Überlappung von EGFP-Fluoreszenz und GLT-1 (C) sowie GLAST-assoziierter Immunfluoreszenz (F) nur auf Somata und Fortsätzen von Astrozyten mit starker EGFP-Fluoreszenz (Pfeilen). Auf Astrozyten mit schwacher EGFP-Fluoreszenz konnte keine Glutamat-Transporter-assoziierte Immunfluoreszenz gefunden werden. Die Bilder sind einzelne Ebenen aus Aufnahmen eines konfokalen Laserscanning-Mikroskops. Länge der Messbalken: $20 \mu \mathrm{M}$. 


\subsubsection{Elektrophysiologische Messungen von AMPA/Kainat-Rezeptor- Strömen in Astrozyten}

Ein Zusammenspiel von Glutamat-Rezeptoren und der daraus resultierenden Depolarisation und von spannungsabhängigen auswärts gleichrichtenden $\mathrm{K}^{+}$-Kanälen wurde als ein Regulationsmechanismus für Gen-Expression in glialen Vorläuferzellen beschrieben (Pende et al. 1994). Die Ko-Expression von ionotropen Glutamat-Rezeptoren (besonders des AMPA-Typs) und

A

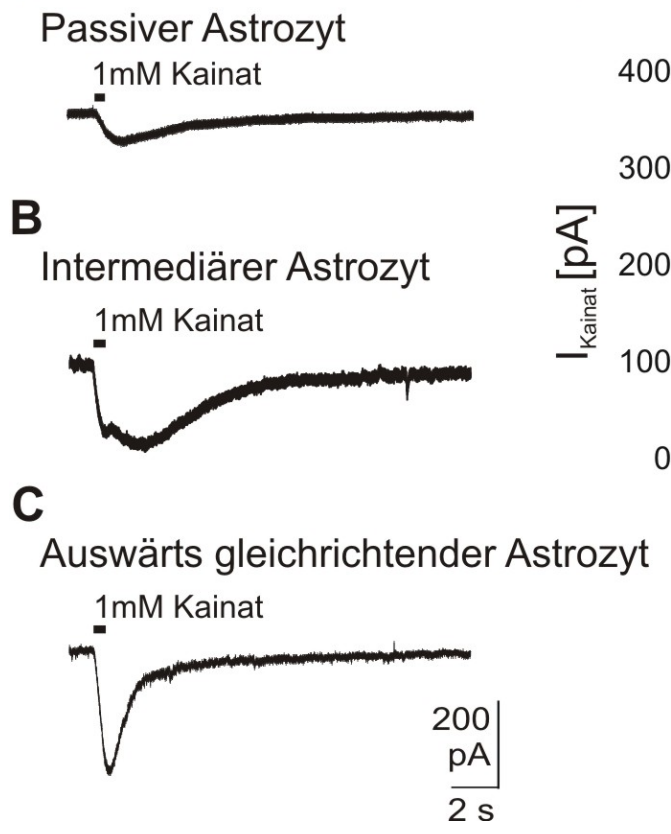

Abb. 21: Expression von Glutamat-Rezeptor-Strömen in verschiedenen Astrozyten-Typen. A-C- Whole-Cell-Voltage-Clamp-Ströme in verschiedenen Astrozyten nach Lokalapplikation von $1 \mathrm{mM}$ des AMPA-Typ-GlutamatRezeptor-Agonisten Kainat. $500 \mathrm{nM}$ TTX und $100 \mu \mathrm{M} \mathrm{CdCl}_{2}$ wurden der Badlösung zur Vermeidung indirekter Effekte zugefügt. D: Mittlere Amplitude des maximal gemessenen Kainat-induzierten Einwärtsstroms in den drei Astrozyten-Gruppen. Daten als Mittel \pm Standardmessfehler, keine signifikanten Unterschiede beim One-Way ANOVA Test. auswärts gleichrichtenden $\mathrm{K}^{+}$Kanälen ist in Astrozyten aus verschiedenen Hirnregionen beschrieben, nämlich in jungen Bergmann-Gliazellen des Cerebellums (Muller et al. 1992; Muller et al. 1994) sowie in frisch isolierten Astrozyten im Hippocampus (Jabs et al. 1994; Matthias et al. 2003).

Übereinstimmend mit dieser Hypothese führte eine lokale Applikation des AMPA-TypGlutamat-Rezeptor-Agonisten

Kainat $(1 \mathrm{mM})$ auf bei $-80 \mathrm{mV}$ geklemmte auswärts gleichrichtende Astrozyten zu großen Einwärtsströmen $(242 \pm 93$ pA; $n=7)$. Ein vergleichbarer Einwärtsstrom konnte in intermediären Astrozyten gemessen werden (192 $\pm 47 \mathrm{pA} ; \mathrm{n}=12)$. 
Die Kainat-Applikation führte in passiven Astrozyten ebenfalls zu Einwärtsströmen. Diese waren mit einer mittleren Amplitude von $103 \pm 41$ pA (n=7) zwar etwas kleiner als die Ströme in den

500 nm TTX; $100 \mu \mathrm{M} \mathrm{CdCl}_{2}$

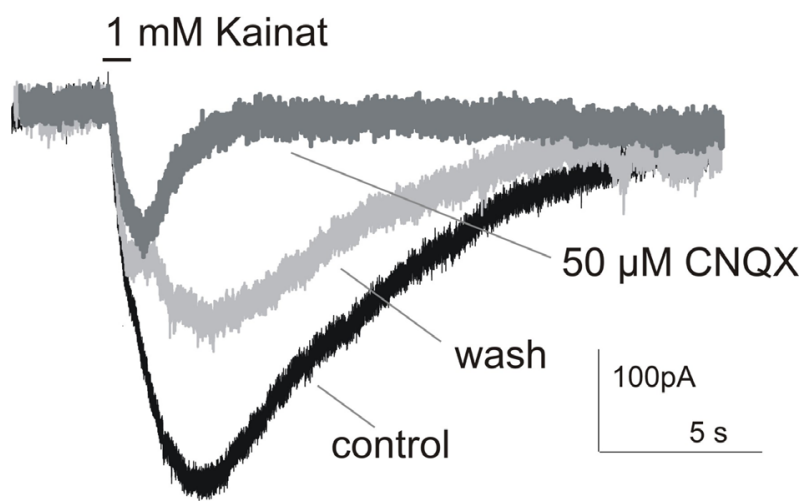

Abb. 22: Blockade des Kainat-induzierten Einwärtsstroms durch den AMPA-Typ-Glutamat-Rezeptor-Blocker CNQX. Unter Kontrollbedingungen (500 nm TTX, $100 \mu \mathrm{M} \mathrm{CdCl}_{2}$ in der Badlösung) durch $1 \mathrm{mM}$ Kainat per Lokalapplikation evozierter Einwärtsstrom in einen passiven Astrozyten (control). Reduktion des Kainat-induzierten Stroms durch 50 $\mu \mathrm{M}$ CNQX und Wiederkehr der Glutamat-Strom-Antwort nach 5-minütigem Auswaschen (wash) des CNQX. anderen Zelltypen, der Unterschied war jedoch bei Überprüfung mit dem OneWay-ANOVA-Test nicht signifikant (Abb. 21). Um auch bei diesen Experimenten indirekt Effekte zu vermeiden, wurden der Badlösung 500 nM TTX sowie $100 \mu \mathrm{M} \mathrm{CdCl}_{2}$ zugeführt. Die Kainat-induzierten Einwärtsströme ließen sich in allen drei Astrozyten-Typen reversibel durch den AMPA-TypGlutamat-Rezeptor-Blocker CNQX (50 $\mu \mathrm{M})$ auf $24,9 \pm 5,3 \%$ der Amplitude reduzieren ( $\mathrm{n}=6$; Abb. 22)

\subsubsection{Ko-Expression von Glutamat-Rezeptoren und Transportern in}

\section{Astrozyten}

In der Publikation Matthias et al. (2003) wurde eine simultane Expression von GlutamatRezeptoren und Glutamat-Transportern in einem einzelnen Astrozyten so gut wie ausgeschlossen. Vor allem die Expression von Glutamat-Rezeptoren vom AMPA-Typ in passiven Astrozyten konnte im Hippocampus nicht nachgewiesen werden. In der vorliegenden Arbeit konnte jedoch in mehreren Astrozyten Ströme von Glutamat-Transportern und Glutamat-Rezeptoren gemessen werden. In einem von 7 passiven Astrozyten, bei denen sowohl $1 \mathrm{mM}$ Kainat als auch $1 \mathrm{mM}$ DAspartat unter den oben angegebenen Bedingungen appliziert wurde (5 von 11 intermediären; 0 von 6 auswärts gleichrichtenden Astrozyten) konnte sowohl ein D-Aspartat-induzierter als auch ein 
Kainat-induzierter Einwärtsstrom von jeweils mehr als 100 pA Amplitude gemessen werden (Abb. 23).

Um diese Daten zu verifizieren, wurden Antworten auf die lokale Applikation von $1 \mathrm{mM}$ Glutamat in allen drei Astrozyten-Typen sowie deren Blockierbarkeit durch Glutamat-Rezeptor- und Transporter-Blocker gemessen (Abb. 24). Dieses Experiment wurde in Zusammenarbeit mit Herrn cand. med. Nestoras Papadopoulos durchgeführt.

Um indirekte Effekte durch synaptische Transmission und mitaktivierte benachbarte Neurone zu vermeiden, wurden der Badlösung $500 \mathrm{nM}$ TTX, $100 \mu \mathrm{M} \mathrm{CdCl}_{2}$ sowie $100 \mu \mathrm{M}$ DL-2-Aminophosphopentanoinsäure (AP-5), $10 \mu \mathrm{M}$ Strychnin und $20 \mu \mathrm{M}$ Bicucullin hinzugefügt.

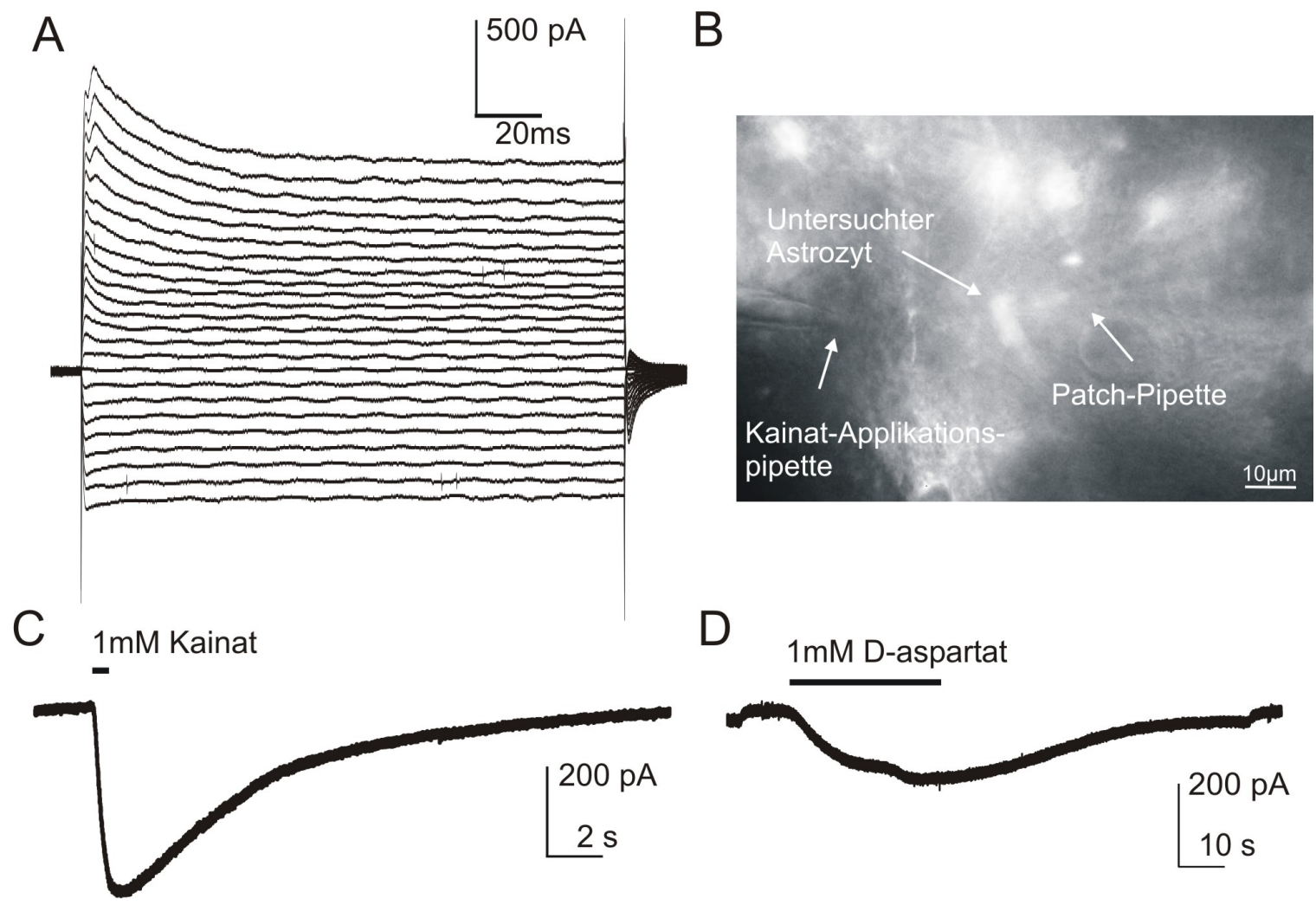

Abb. 23: Glutamat-Rezeptor und Glutamat-Transporter-Ströme in einem Astrozyten vom intermediären Typ. A: StromSpannungsprotokoll (wie oben beschrieben) eines intermediären Astrozyten. B: Situs in der ventralen respiratorischen Gruppe. Zu erkennen ist der im Vergleich zu anderen Zellen schwach EGFP-fluoreszierende gemessene Astrozyt, die Patch-Pipette sowie die Glutamat-Applikationspipette. C: In Whole-Cell-Voltage-Clamp-Technik gemessener Einwärtsstrom nach Lokalapplikation von $1 \mathrm{mM}$ des AMPA-Typ-Glutamat-Rezeptor-Agonisten Kainat. D: Einwärtsstrom gemessen in dem selben Astrozyten nach Badapplikation von $1 \mathrm{mM}$ des Glutamat-Transporter-Agonisten D-Aspartat. 
$1 \mathrm{mM}$ Glutamate per Lokalapplikation führte zu Einwärtsströmen mit Amplituden von -112.0 \pm $54.2 \mathrm{pA}(\mathrm{n}=3)$ in passiven sowie $-90.2 \pm 35.6 \mathrm{pA}(\mathrm{n}=3)$ in auswärts gleichrichtenden Astrozyten. Der Rezeptor-Blocker CNQX $(50 \mu \mathrm{M})$ reduzierte den Strom in passiven Astrozyten um $50.8 \pm$ $13.9 \%(n=3)$. In auswärts gleichrichtenden Astrozyten wurden $78 \pm 1.3 \%(n=3)$ des Glutamatinduzierten Stroms durch $50 \mu \mathrm{M}$ CNQX blockiert, es konnte jedoch bei normalverteilten Daten mit dem t-test kein signifikanter Unterschied nachgewiesen werden $(\mathrm{p}=0.118)$.

\section{A}

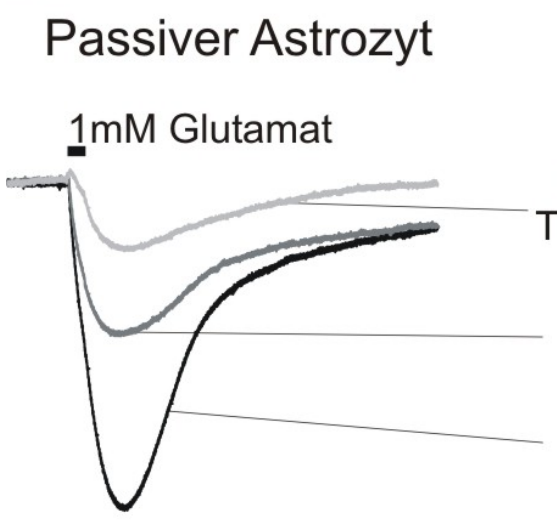

C

\section{Passiver Astrozyt}

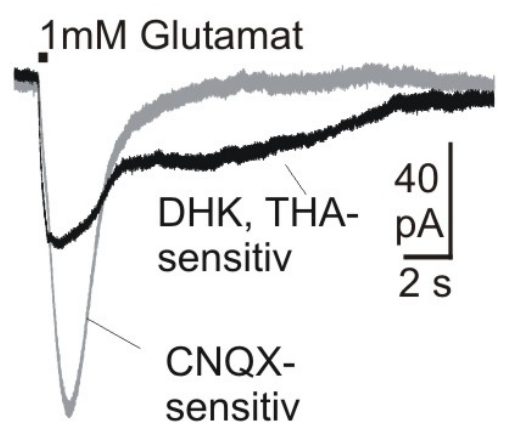

\section{B}

\section{Auswärts gleichrichtender}

Astrozyt $1 \mathrm{mM}$ Glutamat

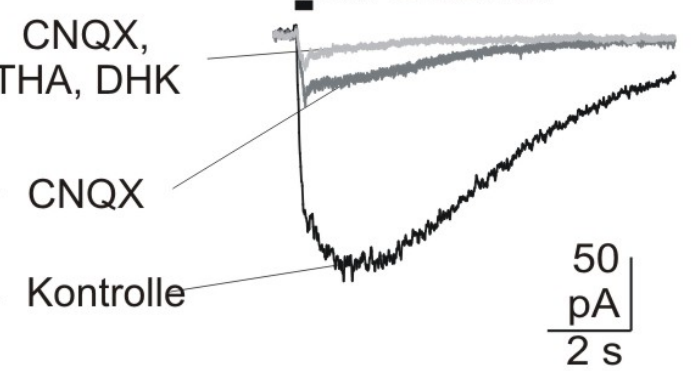

D

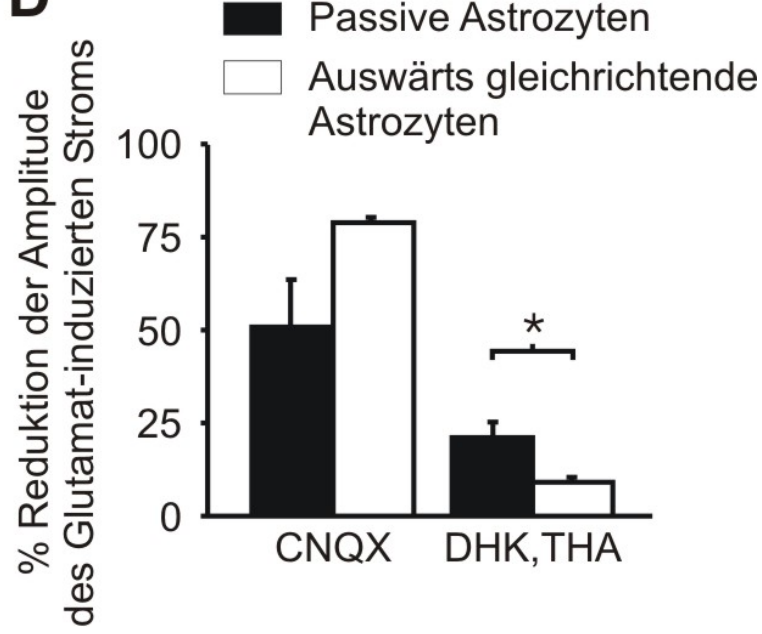

Abb. 24: Unterschiedliche Glutamat-induzierte Einwärtsströme in passiven und auswärts gleichrichtenden Astrozyten. A: Durch $1 \mathrm{mM}$ Glutamat induzierte Ströme in einem passive Astrozyten unter Kontrollbedingungen (500 nM TTX, $100 \mu \mathrm{M} \mathrm{CdCl}_{2}, 50 \mu \mathrm{M}$ AP5, $20 \mu \mathrm{M}$ Bicucculin, $10 \mu \mathrm{M}$ Strychnin), nach Blockade der AMPA-Rezeptoren durch 50 $\mu \mathrm{M}$ CNQX, und nach Blockade der Rezeptorströme durch $300 \mu \mathrm{M}$ Dihydrokainat (DHK) und $50 \mu \mathrm{M} \beta-$ Threohydroxyaspartat (THA). B: Das gleiche Experiment durchgeführt mit einem auswärts gleichrichtenden Astrozyt. C: Punkt-zu-Punkt-Subtraktionen der so in einem passiven Astrozyten aufgezeichneten Ströme zeigen die unterschiedliche Kinetik des Rezeptor-Blocker-sensitiven und des Transporter-Blocker-sensitiven Stroms. D: Mittlere Reduktion des Glutamat-Stroms durch Rezeptor-Blocker (CNQX) und Transporter-Blocker (THA+DHK) in verschiedenen Astrozytentypen (Daten als Mittel \pm Standardmessfehler, signifikant unterschiedlich $(*)$ bei $\mathrm{p}<0.05$ ). 
Eine zusätzliche Blockade der Glutamat-Transporter durch den GLT-1-Blocker Dihydrokainat (DHK, $300 \mu \mathrm{M}$ ) und den kompetitiven Glutamat-Transporter-Blocker $\beta$-Threo-hydroxyaspartat (THA, $50 \mu \mathrm{M})$ führte in passiven Astrozyten zu einem größeren Effekt als in auswärts gleichrichtenden Astrozyten. In den passiven Zellen bewirkten DHK und THA eine weitere Reduktion des initialen Glutamatstromes um $20.0 \pm 2.6 \%$ (n=3). Dieser Effekt war signifikant (ttest bei normalverteilten Daten, $\mathrm{p}=0.015$ ) größer als in den auswärts gleichrichtenden Astrozyten, wo durch DHK und THA nur $9.0 \pm 1.3 \%(\mathrm{n}=3)$ des initialen Glutamat-Stromes blockiert wurden. Eine Punkt-zu-Punkt-Subtraktion der Kurven zeigt die deutlich schnellere Kinetik des CNQXsensitiven Stroms (d.h. der AMPA-Rezeptor-Komponente) im Vergleich zu dem THA/DHKsensitiven Strom (d.h. der Transporter-Komponente).

\subsubsection{Nachweis von mRNA für Glutamat-Rezeptoren und Transporter durch Einzelzell-RT-PCR}

Eine andere Strategie zum Darstellung simultaner Expression von Glutamat-Transportern und Glutamat-Rezeptoren ist der Nachweis von mRNA für die genannten Proteine mittels Einzelzellreverser-Transkriptions-Polymerase-Kettenreaktion (Einzelzell-RT-PCR). Die reverse Transkription sowie die PCR wurden von Dr. rer. nat. Johannes Hirrlinger (Max-Planck Institut für experimentelle Medizin, Göttingen) durchgeführt.

Es wurde insgesamt aus 37 grün fluoreszierenden Astrozyten in der ventralen respiratorischen Gruppe (17 passiv; 15 intermediären; 5 auswärts gleichrichtende Astrozyten) Zytoplasma gewonnen. Davon konnte mittels RTPCR in 34 Zellen $(16 / 13 / 5)$ ein Signal

\begin{tabular}{|c|c|c|c|}
\hline $\begin{array}{c}\text { Astrozytentyp } \\
\text { Signal }\end{array}$ & Passiv & Intermediär & $\begin{array}{c}\text { Auswärts } \\
\text { gleichrichtend }\end{array}$ \\
\hline Kein Signal & 16 & 13 & 3 \\
\hline$\beta$-Aktin & 12 & 13 & 2 \\
\hline $\begin{array}{c}\text { Glutamat-Transporter } \\
\text { (GLT-1 und/oder } \\
\text { GLAST) }\end{array}$ & 14 & 6 & 3 \\
\hline $\begin{array}{c}\text { AMPA-Typ Glutamat } \\
\text { Rezeptor (RI-R4) }\end{array}$ & 3 & 3 & 0 \\
\hline Transporter + Rezeptor & 3 & 2 & 0 \\
\hline Gesamt-Zellen & 17 & 15 & 5 \\
\hline
\end{tabular}

Tab. 4: Ergebnisse der Einzelzell-RT-PCR zum Nachweis von Glutamat-Transporter- und Rezeptor-mRNA in verschiedenen Astrozytentypen in der VRG 
erfasst werden. In 28 Zellen (12/13/3) konnte mRNA für das Kontroll-Protein $\beta$-Aktin gefunden werden. mRNA für die glialen Glutamat-Transporter GLT-1 und/oder GLAST wurde in 23 Astrozyten aller drei Zellgruppen (14/6/3) gefunden. Nur in 6 Zellen (3/3/0; und damit in passiven und intermediären Astrozyten) konnte mRNA für eine oder mehrere Subtypen des AMPA-TypGlutamat-Rezeptors nachgewiesen werden (Abb. 25). Leider zeigte auch die Positiv-Kontrolle kein
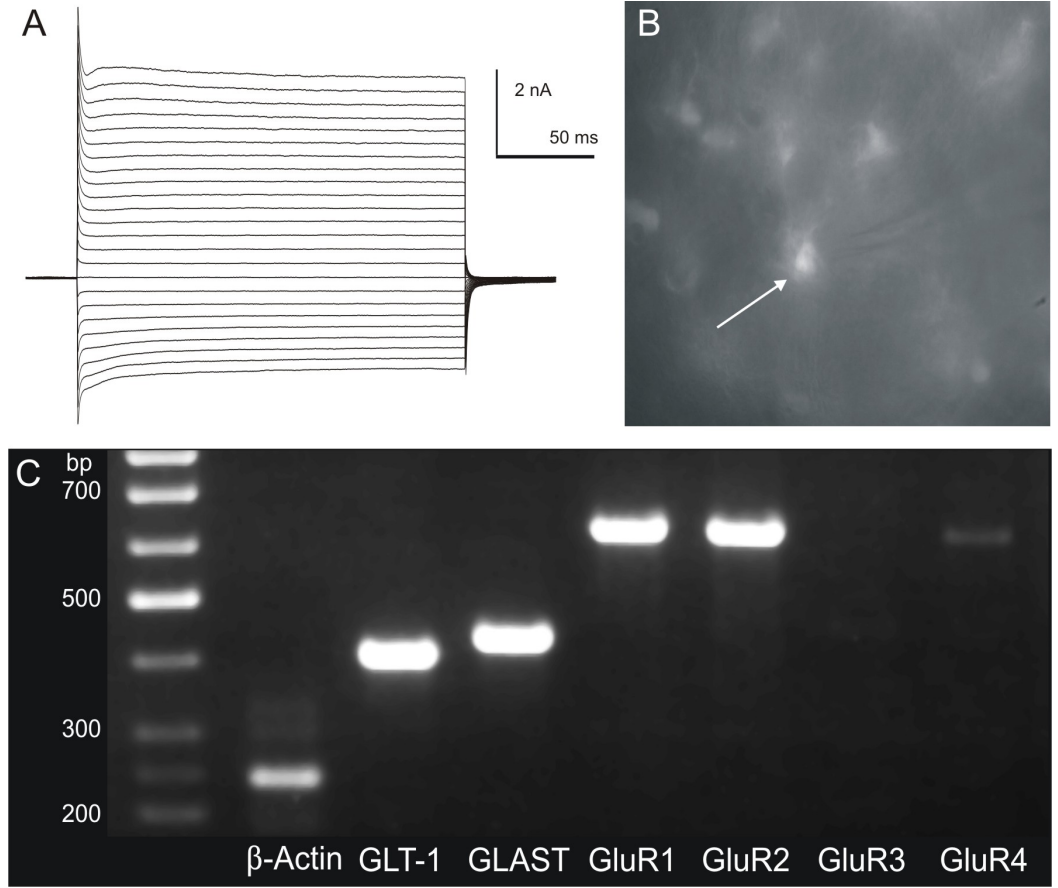

Abb. 25: Expression von Glutamat-Rezeptor- und Glutamat-Transporter-mRNA in einem Astrozyten, nachgewiesen durch Einzelzell-RT-PCR. A: Whole-CellVoltage-Clamp-Aufzeichnung eines intermediären Astrozyten mit Spannungssprüngen auf -170 bis $+70 \mathrm{mV}$ von $-80 \mathrm{mV}$ Haltepotential. B: CCDKamera-Aufnahme dieses Astrozyten mit starker EGFP-Fluoreszenz. C: Die Einzelzell-RT-PCR des in A und B dargestellten intermediären Astrozyten weist mRNA für die glialen Glutamat-Transporter GLT-1 und GLAST sowie für die AMPA-Typ Glutamat-Rezeptor-Untereinheiten GluR1, GluR2 und GluR4 nach. positives Signal für die

Untereinheiten 1,3 und 4

des AMPA-Typ-Glutamat-

Rezeptors. Das bedeutet, dass in Zellen, in denen mittels dieses Experiments ein positives Signal für mRNA für Untereinheiten des AMPA-Typ-GlutamatRezeptors detektiert werden konnte, diese auch wirklich mRNA dieses Typ enthielten. Für Zellen, in denen kein Signal für diese mRNA gefunden wurde, kann nicht ausgeschlossen werden, dass sie trotzdem die gesuchte mRNA enthalten. Die Negativkontrollen brachten keinerlei Amplifikationsprodukte hervor. Zusammenfassend konnte in 5 Astrozyten (3/2/0) eine Koinzidenz von Glutamat-Transporter- und Glutamat-Rezeptor-mRNA nachgewiesen werden (Ergebnisse der Einzelzell-RT-PCR zusammengefasst in Tab.4). 


\subsection{Expression von neuronalen und glialen Proteinen in verschiedenen Astrozyten-Typen}

Die kräftige Antwort auf den Glutamat-Rezeptor-Agonisten Kainat, so gut wie keine GlutamatTransporter-Ströme, eine geringere EGFP-Expression, die A-Typ- $\mathrm{K}^{+}$-Ströme sowie die fehlenden $\mathrm{K}^{+}$-Einwärtsströme in auswärts gleichrichtenden Astrozyten lassen ahnen, dass diese Zellen nicht nur verschiedene Funktionen haben verglichen mit anderen Astrozyten, sondern dass sie eine

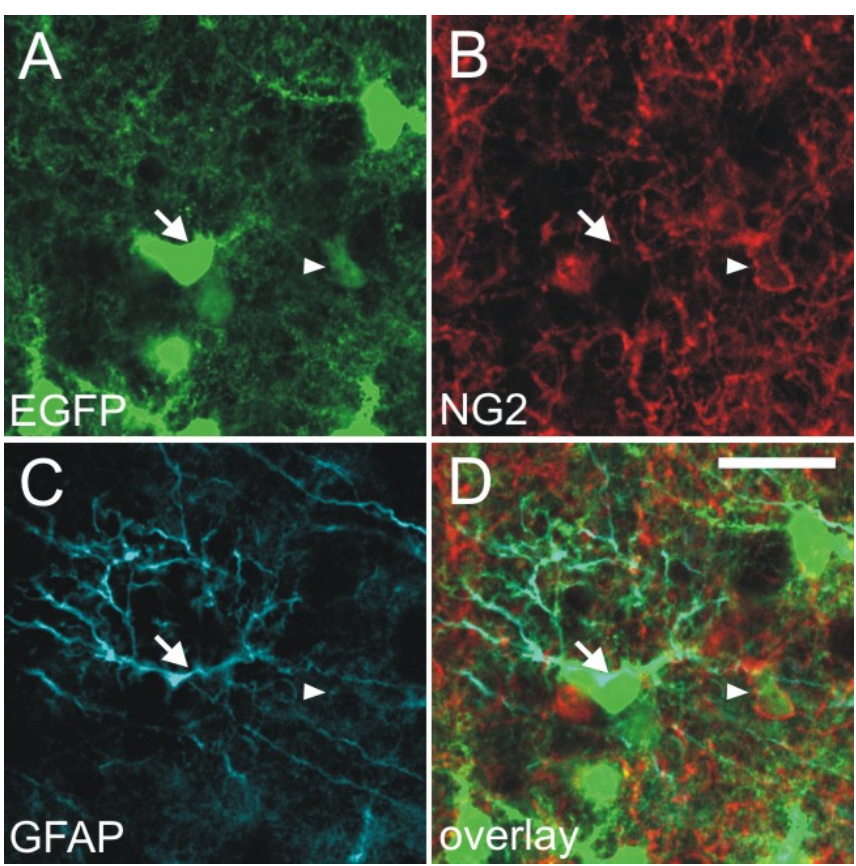

Abb. 26: Immunhistochemische Färbungen gegen NG2 und GFAP. A-D: Konfokale LSM-Aufnahme aus der ventralen respiratorischen Gruppe nach einer Doppel-Immunfärbung in einem Hirnstammschnitt einer 2 Tage alten TgN(hGFAP-EGFP)-Maus mit den Fluoreszenzfarbstoff EGFP (A) exprimierenden Astrozyten, gegen das Proteoglykan NG2 (B) sowie das gliale saure Faserprotein GFAP (C). NG2-Expression zeigt sich nur in Astrozyten mit schwacher EGFP-Expression (Pfeilspitzen), während GFAP-Expression nur in stark EGFP-fluoreszierenden Astrozyten zu finden ist (Pfeile). D: Keine Zelle zeigt eine KoExpression von NG2 und GFAP. Länge des Messbalkens: $20 \mu \mathrm{M}$. hoher EGFP-Expression zeigten keinerlei Immunoreaktivität gegen das Proteoglykan NG2 (Abb. 26).

eigene Zellpopulation, einen eigenen Zelltyp oder eventuell ein anderes Entwicklungsstadium repräsentieren. Um diesen Fragen nachzugehen, wurden diverse immunohistochemische Experimente durchgeführt Damit sollte die Expression von Markern verschiedener Differenzierungsstadien neuronaler und glialer Zelllinien untersucht werden.

Es konnte die Expression des Proteoglykans NG2, welches gliale Vorläuferzellen identifiziert (DiersFenger et al. 2001) in Astrozyten mit niedriger Expression von EGFP nachgewiesen werden. Astrozyten mit 
NG2-positive und schwach EGFP-fluoreszierende Zellen wurden in Mäusen verschiedenen Alters (p2-p23) gefunden. Im Alter von 2 Tagen postnatal waren $53 \%$ der schwach fluoreszierenden Zellen NG2-positiv, im Alter von 23 Tagen war diese Rate mit $63 \%$ vergleichbar.
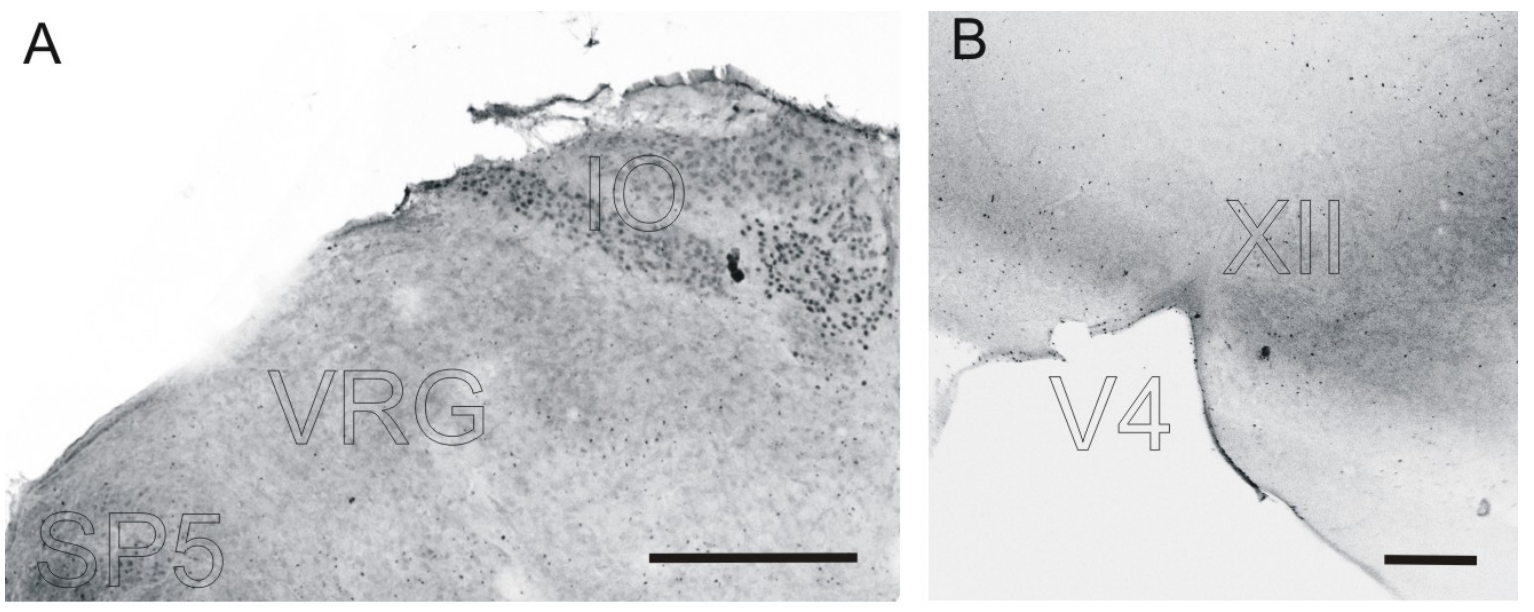

Abb. 27: Immunhistochemische Färbung gegen das früh postmitotische Neuronen-Markerprotein TUC-4 (ToaD 64, Ulip, CRMP). Die TUC-4-Immunfluoreszenz in den Übersichtsaufnahmen der VRG und der inferioren Olive (A) sowie des Ncl. n. hypoglossi (B) ist als invertierte Grauskala dargestellt. Die Expression von TUC-4 ist im Hirnstamm auf Bereiche ohne Zugehörigkeit zum respiratorischen Nervensystem wie der inferioren Olive und den spinalen Trigeminuskern (SP5) beschränkt. In der ventralen respiratorischen Gruppe (VRG) und im Ncl. n. hypoglossi (XII) in Höhe des kaudalen vierten Ventrikels (V4) konnten keine TUC-4-positiven Zellen beobachtet werden. Länge der Messbalken: $200 \mu \mathrm{M}$.

In Doppelimmunfärbungen gegen NG2 und das gliale saure Faserprotein GFAP wurde nun die Position der auswärts gleichrichtenden Astrozyten bezüglich astrozytärer Entwicklungsstadien genauer untersucht (Abb. 26).

Im Alter von 2 Tagen postnatal zeigten sich viele stark GFAP-positive, NG2-negative hell fluoreszierende Zellen, jedoch keine schwach fluoreszierende NG2-positive Zelle mit GFAPExpression in der ventralen respiratorischen Gruppe.

Um nach möglichen Hinweisen auf eine neuronale Zelllinie zu suchen, wurden Doppelfärbung gegen den frühen postmitotischen neuronalen Marker TUC-4 (ToaD 64 (Turned on after Division), Ulip, CRMP; Quinn et al. 2003) und NG2 durchgeführt (Abb. 27).

Dabei wurden in 2 Tage alten Mäusen weder in der ventralen respiratorischen Gruppe, noch im Kerngebiet des N. hypoglossus TUC-4-positive Zellen gefunden. In denselben Hinstammschnitten konnten in anderen Regionen, so z.B. im inferioren Olivenkern, TUC-4-positive Zellen identifiziert 
werden. Keine dieser Zellen zeigte jedoch eine Ko-Lokalisation von NG2- und TUC-4Immunfluoreszenz oder eine EGFP-Fluoreszenz.

Die Doppel-Immunfärbungen gegen TUC-4/NG2 und GFAP/NG2 wurden in Zusammenarbeit mit Petra Pawlowski und Dr. Johannes Hirrlinger (Max-Planck Institut für Experimentelle Medizin, Göttingen) durchgeführt.

\subsection{Räumliche Beziehungen von Astrozyten, Neuronen und Blutgefäßen}

Der große Anteil an schwach fluoreszierenden Zellen unter den EGFP exprimierenden Zellen weist auf eine hohe Dichte an auswärts gleichrichtenden Astrozyten im respiratorischen Netzwerk hin. Ein interessanter Aspekt ist nun die morphologische Beziehung dieser Zellen zu anderen Astrozyten, Neuronen und Blutgefäßen.

In cLSM-Aufnahmen der EGFP-positiven Zellen erkennt man, wie hell fluoreszierende Zellen mit ihren Fortsätzen Strukturen umfassen, hinter denen man Kapillaren und Neurone erkennen kann (Abb. 8;29). Da die Fortsätze von schwach fluoreszierenden Zellen nur schwer optisch aufzulösen sind, wurden sowohl schwach als auch hell fluoreszierende Zellen sowie Neurone während elektrophysiologischer Experimente, mit denen sich auch der Zelltyp bestimmen ließ, mit einem rot fluoreszierenden Farbstoff (Alexa Fluor 568) gefüllt. Durch dreidimensionale Aufnahmen des fixierten Gewebes mittels eines cLSM konnten dann hochauflösend die räumlichen Verhältnisse der verschiedenen Zelltypen dargestellt werden (Abb. 28;29;30).

Gefüllte passive Zellen umgeben mit ihren Fortsätzen Strukturen, hinter denen sich wahrscheinlich Neurone und Blutgefäße verbergen. Füllt man ein Neuron in unmittelbarer Nähe eines hell fluoreszierenden Astrozyten, so erkennt man, wie dessen Fortsätze das Soma sowie die Dendriten des Neurons umgeben (Abb. 28). Ein ähnliches Bild ergab sich, nachdem Farbstoff in schwach fluoreszierende Zellen injiziert wurde. Fortsätze dieser Zellen wanden sich um Blutgefäß-ähnliche Strukturen sowie um andere schwach fluoreszierende Zellen (Abb. 29). 

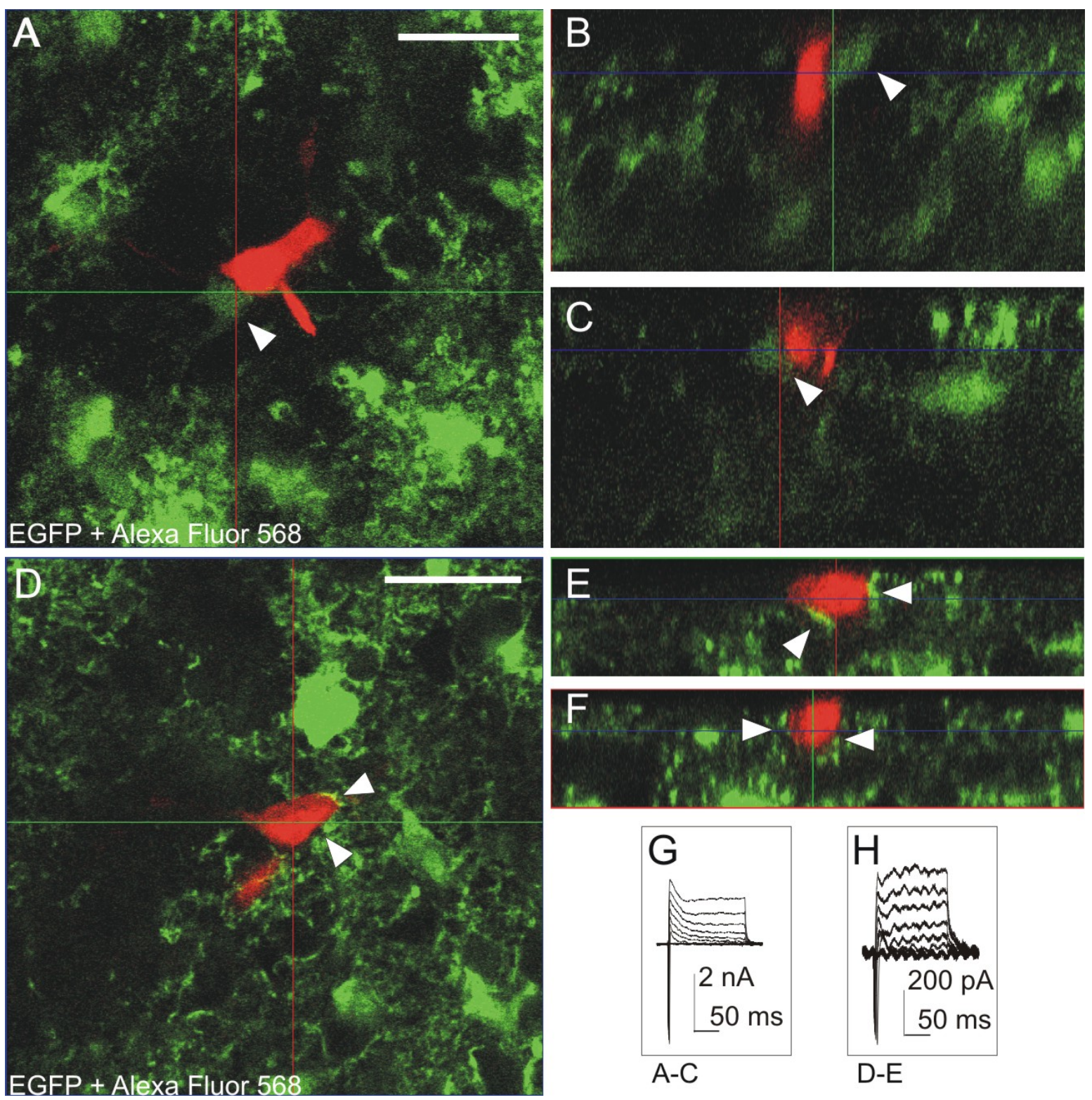

Abb. 28: Zellkontakte zwischen Neuronen und verschiedenen Astrozyten-Typen. A-C: Während eines Whole-CellVoltage-Clamp-Experiments (Strom-Spannungsprotokoll in G) mit dem rot fluoreszierenden Farbstoff Alexa Fluor 568 gefülltes Neuron im Kerngebiet des Nervus hypoglossus in unmittelbarer Nähe zu dem Soma eines schwach EGFPfluoreszierenden Astrozyten. D-F: Ein vergleichbar durchgeführtes Experiment zeigt ebenfalls ein gefülltes Neuron (Strom-Spannungsprotokoll in H), welches diesmal von den Fortsätzen eines stark EGFP-fluoreszierenden Astrozyten umhüllt wird. Die Bilder A-C und D-F sind einzelne Schnittebenen von mit einem konfokalen LSM aufgezeichneten Bildern. A und D zeigen die Aufsicht (Schnittebene: blaue Linie), B und E die rekonstruierte horizontale (Schnittebene: grüne Linie), E-F die rekonstruierte senkrechte (Schnittebene: rote Linie) Ansicht der Zellen. Länge der Messbalken: 20 $\mu \mathrm{M}$. 

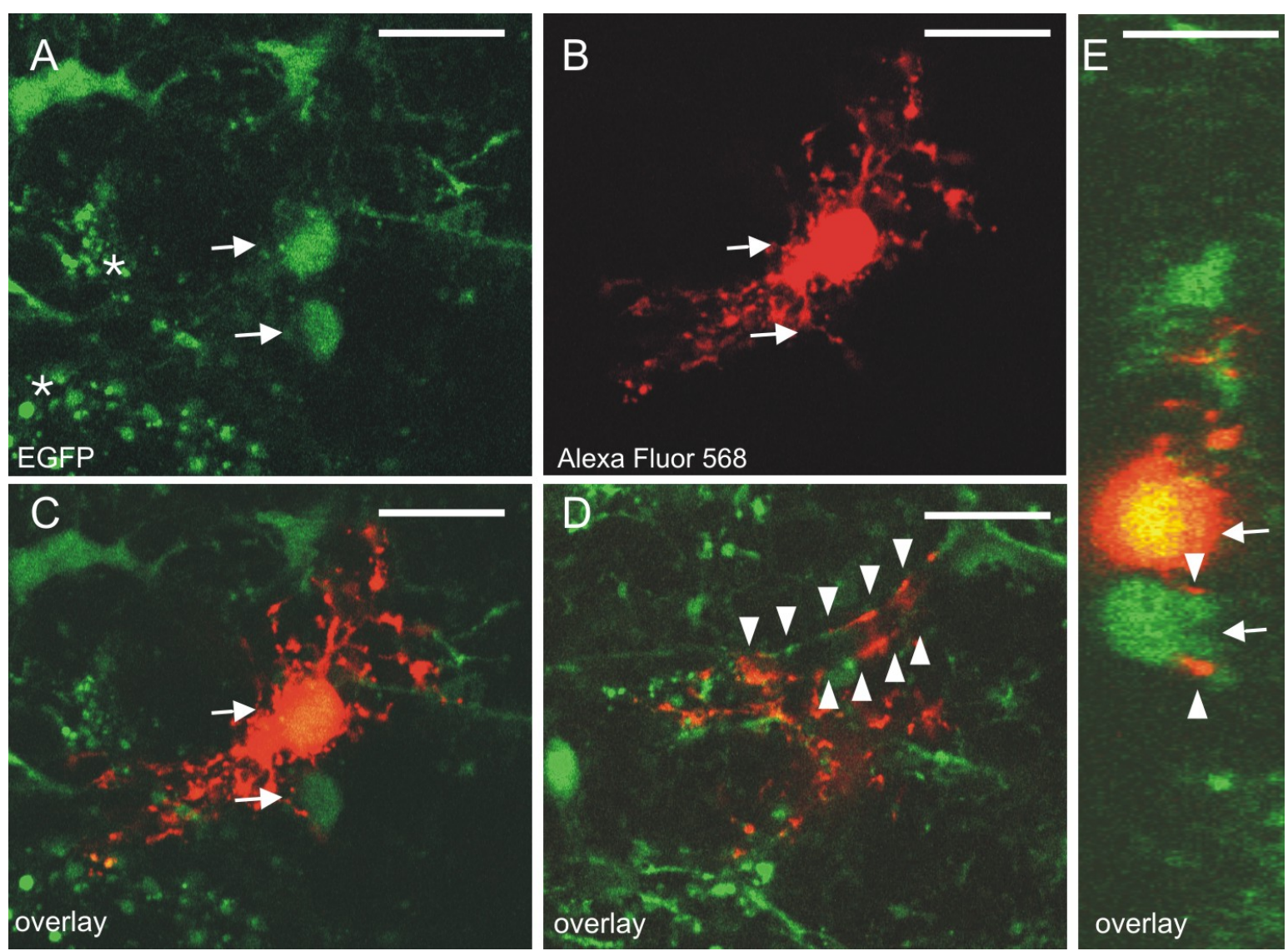

overlay

Abb. 29: Schwach fluoreszierende Astrozyten umfassen mit ihren Fortsätzen Blutgefäße und andere schwach fluoreszierende Zellen. A: Grüne EGFP-Fluoreszenz in zwei schwach fluoreszierenden Zellen (Pfeile). Deutlich stärker ausgeprägte Fluoreszenz in Fortsätzen anderer Zellen (Sterne). B: Während eines Whole-Cell-Voltage-ClampExperiments in eine als auswärts gleichrichtenden Astrozyten identifizierte Zelle injizierter roter Farbstoff Alexa Fluor 568 (oberer Pfeil) in einer einzelnen Schnittebene einer cLSM-Aufnahme. Die Zelle weist die für auswärts gleichrichtende Astrozyten typische knötchenartige Struktur der Fortsätze auf. Der zweite schwach fluoreszierende Astrozyt (unterer Pfeil) nimmt keinen Farbstoff über Gap-junction-Kopplung auf. C: Überlagerung von A und B. D: Andere Schnittebene durch den Fortsatzbaum des Alexa Fluor 568 gefüllten schwach EGFP-fluoreszierenden Astrozyten, dessen Fortsätze teilweise einen Blutgefäß-ähnliche Struktur umschließen. E: Rekonstruierte seitliche Ansicht von C. Zwei mit rotem Farbstoff gefüllte Fortsätze umhüllen von zwei Seiten einen zweiten schwach fluoreszierenden Astrozyten. Länge der Messbalken: $20 \mu \mathrm{m}$. 

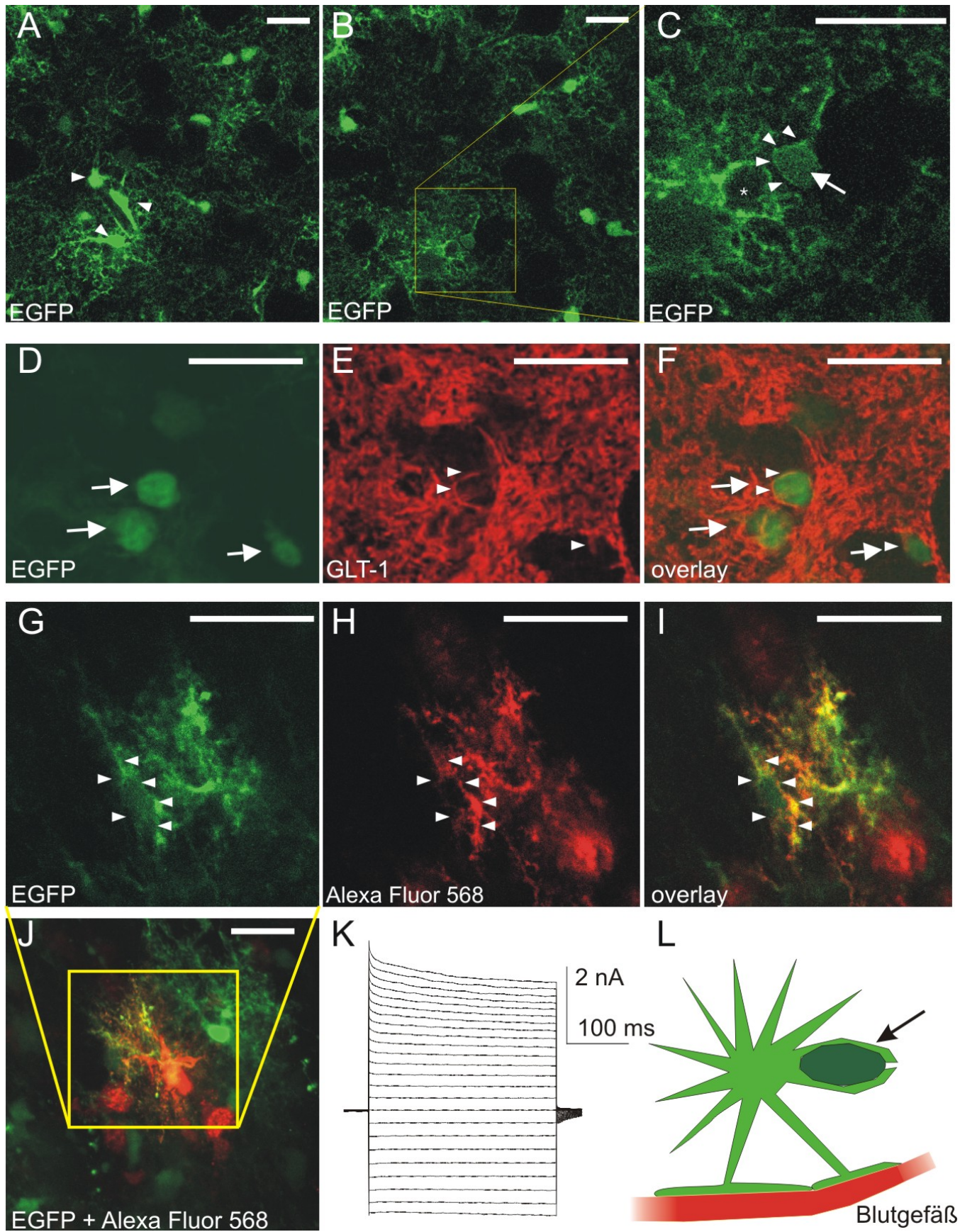

L

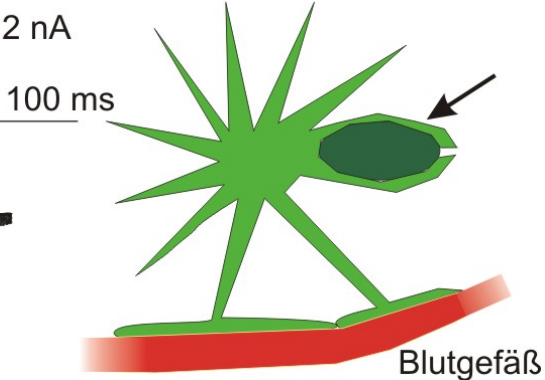

Abb. 30: Hell fluoreszierende Astrozyten umhüllen Blutgefäße und schwach fluoreszierende Zellen. Zellkontakte zwischen verschiedenen Astrozyten. A-C: Fortsätze (C, Pfeilspitzen) von hell fluoreszierenden Astrozyten (A, Pfeilspitzen) umhüllen einen schwach fluoreszierenden Astrozyten (C, Pfeil). A: Einzelne Schnitteebene eines konfokalen LSM-Bildes aus der VRG mit stark EGFP-exprimierenden Astrozyten. Einer dieser Astrozyten umhüllt einen länglichen Hohlraum $(*)$, der wahrscheinlich ein längs angeschnittenes Blutgefäß darstellt. B: $5 \mu \mathrm{M}$ darüber aufgezeichnete Schnittebene desselben Gebietes. C: Eine Ausschnittvergrößerung zeigt das nun quer angeschnittene Gefäß (*) sowie den von hellen Fortsätzen (Pfeilspitzen) umhüllten schwach fluoreszierenden Astrozyten (Pfeil). D-F: Immunfärbung gegen den glialen Glutamat-Transporter GLT-1 in der VRG einer 9 Tage alten TgN(hGFAP-EGFP)Maus. GLT-1-positive Strukturen (Pfeilspitzen) umhüllen GLT-1-negative schwach EGFP-fluoreszierende Astrozyten. G-K: Ein mit dem roten Farbstoff Alexa Fluor $568(\mathrm{H})$ gefüllter passiver (Whole-Cell-Voltage-Clamp-Aufzeichnung in $\mathrm{K})$ stark fluoreszierender Astrozyt $(\mathrm{G})$ umhüllt mit seinen Fortsätzen (Pfeilspitzen) einen schwach fluoreszierenden Astrozyten. G-I Einzelne Schnittebenen eines konfokalen LSM-Bildes und Ausschnittvergrößerungen von der MaximalIntensitäts-Projektion H. J: Schematische Darstellung eines hell fluoreszierenden Astrozyten, der mit seinen Fortsätzen sowohl Blutgefäße als auch schwach fluoreszierende Astrozyten umhüllt. Länge der Messbalken: $20 \mu \mathrm{M}$. 
Bei einem in der Nähe eines schwach fluoreszierenden Astrozyten liegenden gefüllten Neuron, zeigte sich, dass beide Zellen unmittelbaren Kontakt hatten (Abb. 28).

Bei genauerer Untersuchung von LSM-Bildern EGFP-positiver Zellen konnte um einige schwach fluoreszierende Zellen ein dünner Saum heller EGFP-Fluoreszenz nachgewiesen werden (Abb. 30). Es lag die Vermutung nahe, dass hell fluoreszierende Zellen mit ihren Fortsätze auch schwach fluoreszierende Zellen umgreifen. Um dies nachzuweisen, wurden helle Zellen in der Nähe von schwach fluoreszierenden Zellen mit Alexa Fluor 568 gefüllt. Und tatsächlich konnte so gezeigt werden, dass passive Zellen mit ihren Fortsätzen auswärts gleichrichtende Zellen umfassen.

\subsection{Beteiligung von Astrozyten verschiedenen Typs am astroglialen Synzytium}

Es ist bekannt, dass Astrozyten ein Synzytium bilden. Viele einzelne Zellen sind über Gapjunctions verbunden. Das sind aus Connexinen aufgebaute Verbindungen zwischen den Zellen, die durchlässig für Ionen und niedermolekulare Verbindungen sind. Das astrozytäre Synzytium spielt eine wesentlich Rolle bei der Pufferung lokal ansteigender $\mathrm{K}^{+}$-Konzentrationen (Spatial- $\mathrm{K}^{+}$-
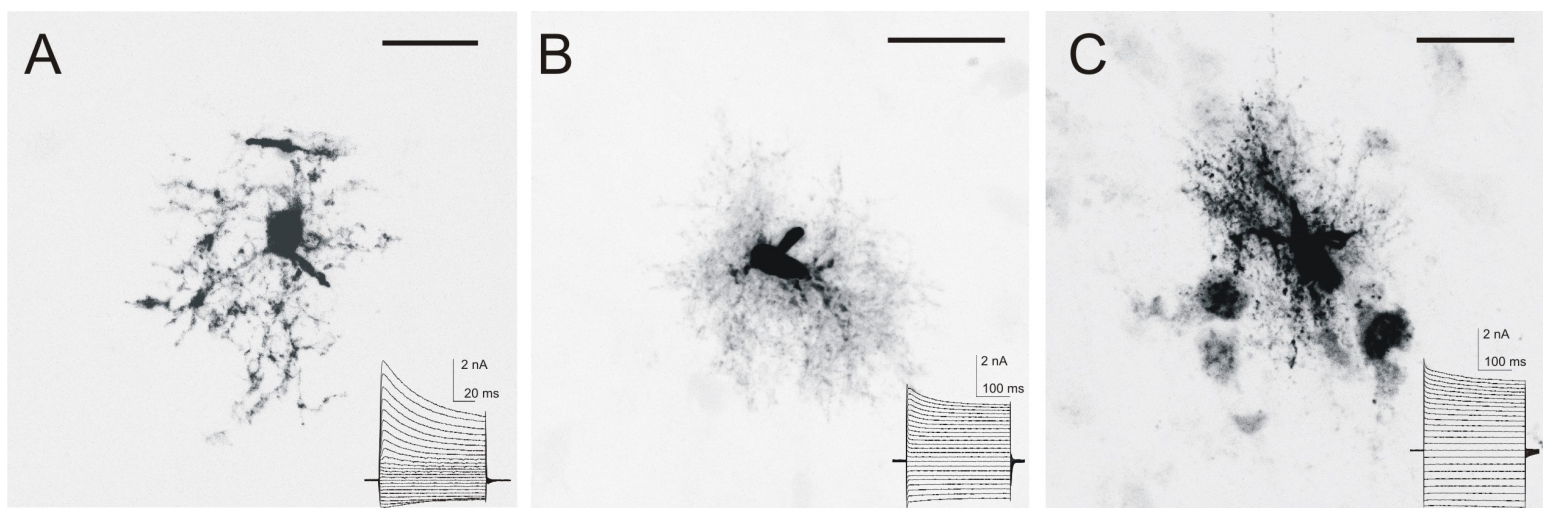

Abb. 31: Gap-junction-Kopplung von Astrozyten verschiedenen Typs. A-C: Als invertierte Graustufenskala dargestellte Fluoreszenz des Farbstoffes Alexa Fluor 568, welcher während Whole-Cell-Voltage-Clamp-Messungen in die untersuchten Zellen injiziert wurde. Rechts unten in den Bildern dargestellt sind die oben beschriebenen StromSpannungs-Protokolle mit Membranpotentialen von $-150 \mathrm{mV}$ bis $+70 \mathrm{mV}$ zur Identifizierung der elektrophysiologischen Eigenschaften der gefüllten Zellen. Während sich nach der Farbstoffbeladung bei auswärts gleichrichtende Astrozyten (A) und intermediären Astrozyten (B) keinerlei andere Zellen füllen, zeigen nach der Füllung von passiven Astrozyten (C) viele andere Zellkörper ein deutliches Fluoreszenzsignal. Länge der Messbalken: $20 \mu \mathrm{m}$. 
Buffering; Kofuji und Newman 2004). Das von den umliegenden Astrozyten aus dem Extrazellulärraum aufgenommene $\mathrm{K}^{+}$kann via Gap-junctions durch Diffusion im astrozytären Synzytium verteilt werden.

Zur Überprüfung der Kopplung von Astrozyten verschiedenen Typs im respiratorischen Netzwerk wurden Astrozyten nach Identifikation ihrer elektrophysiologischen Eigenschaften wie oben beschrieben während Whole-Cell-Voltage-Clamp-Messungen über die Patch-Pipette mit einem niedermolekularen Fluoreszenzfarbstoff gefüllt (Alexa Fluor 568). Nach 5-minütiger Inkubation wurde die Pipette entfernt, das Gewebe fixiert und die gefüllte Zelle im cLSM analysiert. Es wurde überprüft, ob sich der Gap-junction-gängige Farbstoff auch in anderen Zellen ansammelte. Dazu wurden Maximale-Intensitäts-Projektionen von cLSM Bildern mit einer räumlichen Ausdehnung von ca. $100 \mu \mathrm{m}$ x ca. $100 \mu \mathrm{m}$ x ca. 30-70 $\mu \mathrm{m}$ angefertigt. Es wurde nun nur der Kanal, auf dem die Alexa-Fluor-568-Darstellung lag, als invertierte Graustufenskala dargestellt. So waren eventuell über Gap-junction-Kopplung mitgefärbte Zellen gut zu erkennen (Abb. 31).

Auf diese Weise wurden insgesamt 13 Zellen untersucht. Bei zwei untersuchten auswärts gleichrichtenden Astrozyten fand sich keinerlei Kopplung und auch bei keinem von fünf untersuchten intermediären Astrozyten fand sich eine Anfärbung anderer als der im Versuch gefüllten Zelle. Im Gegensatz dazu konnten in der Umgebung von vier der fünf untersuchten passiven Zellen mehrere ebenfalls mit Farbstoff gefüllte Zellen detektiert werden.

Vergleicht man das Kopplungsverhalten von Zellen mit unterschiedlichen Fluoreszenzintensitäten, so ist zu erkennen, dass keine von sieben schwach fluoreszierenden Zellen andere Zellen mit anfärbte. Bei den stark fluoreszierenden Zellen waren vier von fünf an andere Zellen gekoppelt. 


\section{Diskussion}

\subsection{Unterschiedliche Eigenschaften von Astrozyten im respiratorischen Netzwerk}

Der im respiratorischen Netzwerk generierte Atemrhythmus ist lebenswichtig, er muss konstant und stabil über die gesamte Lebenszeit des Individuums erhalten werden. Neben Neuronen sind auch Gliazellen wie z.B. Astrozyten in diesem Netzwerk vorhanden. Stört man die gliale Funktionen wie den Glutamat-Metabolismus oder die Glyzinaufnahme, wird auch der im respiratorischen Netzwerk generierte Rhythmus inhibiert (Hulsmann et al. 2000a, Gomeza et al. 2003).

In meinen Experimenten in der ventro-lateralen Medulla oblongata sowie dem Kerngebiet des Nervus hypoglossus konnte die Existenz funktionell unterschiedlicher Astrozyten gezeigt werden. Es konnten drei wesentliche Gruppen von EGFP-fluoreszierenden Zellen in der TgN(hGFAPEGFP)-Mauslinie beschrieben werden. Diese zeigten Unterschiede in der Expression von Membranionenkanälen, Glutamat-Transportern und Rezeptoren sowie der Expression von Oberflächenproteinen .

Die elektrophysiologische Charakterisierung der Zellen führte zu der Einteilung der Astrozyten in die folgenden drei Gruppen:

EGFP-positive Zellen, die nur passive, d.h. spannungs- und zeitunabhängige Leitfähigkeiten sowohl bei hyper- als auch depolarisierenden Membranpotentialen und damit eine lineare StromSpannungskurve aufweisen, wurden als passive Astrozyten bezeichnet..

EGFP-positive Zellen, die neben passiven Leitfähigkeiten zusätzliche auswärts gleichrichtende transiente Ionenströme (A-Typ- $\mathrm{K}^{+}$-Strom) aufwiesen, wurden als intermediäre Astrozyten bezeichnet. 
EGFP-positive Zellen, die deutlich geringere passive Leitfähigkeiten zeigten, jedoch durch eine auswärts gleichrichtende IV-Kurve imponierten, wurden als auswärts gleichrichtende Astrozyten (outwardly rectifying astrocytes; ORA, nach Zhou und Kimelberg 2000) bezeichnet.

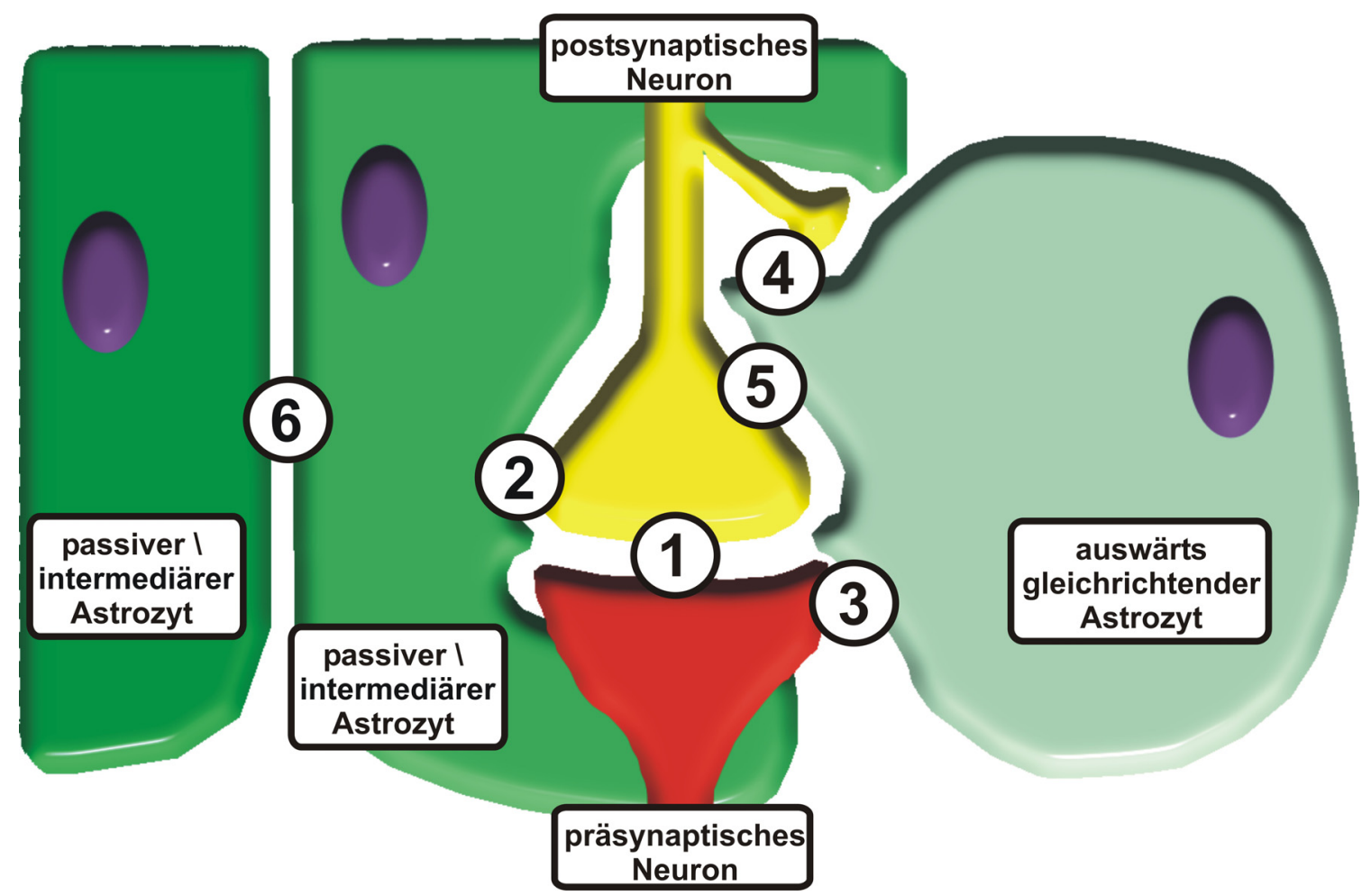

Abb. 32: Zusammenfassende Abbildung: Zellkontakte zwischen Neuronen, NG2-positiven auswärts gleichrichtenden und passiven/intermediären Astrozyten. Die Zahlen markieren Interaktionsschwerpunkte zwischen den verschiedenen Zellen.

1: Synapse mit einem präsynaptischen und postsynaptischen neuronalen Kompartment. Im präsynaptischen Teil werden Neurotransmitter freigesetzt, im postsynaptischen Teil werden diese von Rezeptoren detektiert. Wichtigster exzitatorischer Neurotransmitter im respiratorischen Netzwerk ist Glutamat (Funk et al. 1993)..

2: Passive/intermediäre Astrozyten habe direkten Kontakt zu neuronalen Synapsen. Über Membrantransporter können sie Neurotransmitter aus dem synaptischen Spalt entfernen (Grass et al. 2004). Über Glutamat-Rezeptoren können manche der passiven/intermediären Astrozyten die Umhüllung neuronaler Synapsen steuern (Hulsmann et al. 2000). Über Ionenkanäle können $\mathrm{K}^{+}$-Ionen aus dem Extrazellulärraum aufgenommen werden und so die extrazelluläre Kalium-Konzentration stabilisiert werden (Spatial K ${ }^{+}$-Buffering; Kofuji and Newman 2004).

3: Auswärts gleichrichtende Astrozyten haben ebenfalls Kontakt zu neuronalen Synapsen und können dort möglicherweise über Glutamat-Transporter synaptische Aktivität detektieren (Grass et al. 2004; Butt et al. 2002).

4: Neurone (präsynaptisch) bilden mit auswärts gleichrichtenden Astrozyten (postsynaptisch) Synapsen. Diese Synapsen sind GABAerg und glutamaterg (Bergles et al. 2002; Jabs et al. 2004). Passive/intermediäre Astrozyten könnten über Kontakt zu diesen Synapsen für eine Regulierung von Transmitterkonzentration und -haushalt im präsynaptischen Neuron sorgen.

5: Auswärts gleichrichtende Astrozyten haben Kontakt zu neuronalen Zellkörpern sowie Axonen. Die Kontaktstellen sind dort an Ranvier'schen Schnürringen lokalisiert (Butt et al. 2002).

6: Passive/intermediäre Astrozyten stehen untereinander über Gap-junctions in Kontakt. Darüber können aus dem extrazellulären Raum aufgenommene $\mathrm{K}^{+}$-Ionen im astroglialen Synzytium verteilt werden (Spatial $\mathrm{K}^{+}$-Buffering; Kofuji and Newman 2004). 


\subsection{Stabilisierung der synaptischen Funktion durch Astrozyten mit passiven $\mathrm{K}^{+}$-Leitfähigkeiten und Glutamat-Transportern}

Passive und intermediäre Astrozyten haben viele morphologische und funktionelle Eigenschaften gemeinsam. Sieht man von der zusätzlichen Expression des A-Typ- $\mathrm{K}^{+}$-Stroms in intermediären Astrozyten ab, waren keine signifikanten Unterschiede zwischen diesen Zellgruppen zu finden. Dies führt zu der Annahme, dass diese Gruppen wahrscheinlich Variationen eines Zelltyps darstellen. Sie könnten sowohl funktionelle spezialisierte Zellvarianten als auch unterschiedliche Reifestadien des astrozytären Zelltyps darstellen. Diese Astrozyten lassen sich als Zellen charakterisieren, die für die Stabilisierung der synaptischen Transmission zuständig sind.

Glutamat ist der wichtigste exzitatorische Transmitter im respiratorischen Netzwerk und entscheidend beteiligt an der Generierung des Atemrhythmus (Funk et al. 1993). Passive und intermediäre Astrozyten exprimieren funktionsfähige Glutamat-Transporter. Die während der rhythmischen synaptischen Aktivität freigesetzte Transmittersubstanz kann hiermit effizient aus den synaptischen Spalträumen entfernt werden. Blockade der glialen Glutamat-Transporter durch Dihydrokainat führt zu Anstieg von Frequenz und Amplitude neuronaler Oszillationen im respiratorischen Netzwerk (Funk et al. 1993). Die kompetitive Blockade von GlutamatTransportern durch $\beta$-Threo-hydroxyaspartat sowie die Blockade des glialen Zitratzyklus durch Fluoracetat führt zu einer Senkung von Frequenz und Amplitude der im respiratorischen Netzwerk abgeleiteten rhythmischen Aktivität (Hulsmann et al. 2000b). Dies erklärt sich durch die Unterbrechung des Glutamin-Transfers von Gliazellen zu Neuronen, was zu einem Mangel an exzitatorischem Neurotransmitter in den präsynaptischen Neuronen führt (Hulsmann et al. 2000b). Während der synchronen Aktivität wird außerdem die extrazelluläre $\mathrm{K}^{+}$-Konzentration in diesen Hirngebieten angehoben (gezeigt in vitro und in vivo; Richter et al. 1978; Brockhaus et al. 1993). Passive und intermediäre Astrozyten zeigen große passive, nicht spannungsabhängige Leitfähigkeiten für $\mathrm{K}^{+}$-Ionen. Damit können diese Zellen als ein Puffer für die repetitiv ansteigenden extrazellulären $\mathrm{K}^{+}$-Konzentrationen fungieren. Durch Aufnahme der $\mathrm{K}^{+}$-Ionen und 
Verteilung im astroglialen Synzytium (Spatial K-Buffering, Kofuji und Newman 2004), wird die lokale $\mathrm{K}^{+}$-Konzentration dauerhaft auf einem physiologischen Level gehalten.

Die so erfolgende Regulierung der Glutamat-Konzentration sowie der $\mathrm{K}^{+}$-Puffer-Mechanismus kann die ständig andauernde rhythmische Aktivität der respiratorischen Neuronen sichern.

Die Morphologie der stark fluoreszierenden Astrozyten, die elektrophysiologisch größtenteils Astrozyten vom passiven oder vom intermediären Typ repräsentieren, unterstützt die Hypothese einer supportiven Funktion dieser Zelltypen. Die Fortsätze von hell fluoreszierenden Zellen erreichen und umhüllen sowohl Blutgefäße als auch Neurone und deren Fortsätze.

Durch den Nachweis von Farbstoffverteilung innerhalb des astroglialen Synzytiums konnte eine gap-junctionale Kopplung von Astrozyten mit starker EGFP-Expression bewiesen werden. Diese Kopplung von Zellen mit großen passiven $\mathrm{K}^{+}$-Leitfähigkeiten ist für den $\mathrm{K}^{+}$-puffernden Mechanismus im respiratorischen Netzwerk unabdingbar (McKhann et al. 1997).

\subsection{Stellen auswärts gleichrichtende Astrozyten eine eigene Zellpopulation dar?}

Astrozyten vom intermediären und passivem Typ haben aufgrund ihrer Eigenschaften eine stabilisierende Funktion auf die synaptische Aktivität im respiratorischen Netzwerk. Auswärts gleichrichtenden Astrozyten fehlen die Möglichkeiten zur Transmitteraufnahme und zur $\mathrm{K}^{+}$Pufferung. In diesen Zellen konnte außerdem keine Expression des intermediären Filaments GFAP nachgewiesen werden. Somit kann angenommen werden, dass es sich hierbei nicht um reife funktionelle Astrozyten handelt.

In der Literatur sind verschiedene Zellen in unterschiedlichen Hirnarealen beschrieben, die Eigenschaften der auswärts gleichrichtenden Astrozyten teilen. Diesen Zellen wurden verschiedene Funktionen zugeschrieben, so dass ein Vergleich bzw. eine Abgrenzung der auswärts gleichrichtenden Astrozyten zu diesen Zellen nötig ist. 
Die in auswärts gleichrichtenden Astrozyten nachgewiesene Expression von A-Typ- $\mathrm{K}^{+}-\mathrm{Kanälen}$ und ionotropen Glutamat-Rezeptoren vom AMPA-Typ ist charakteristisch für Zellen mit Migrations- und Proliferationspotential, d.h. für Vorläufer-Zellen ("Progenitor-Cells"; Pende et al. 1994; Knutson et al. 1997; Wang et al. 2000). Ein wesentliches Merkmal der auswärts gleichrichtenden Astrozyten ist die Expression des membranständigen Proteoglykans NG2. Dieses wurde u.a. in verschiedenen Zellpopulationen nachgewiesen, die als Vorläufer für gliale Zellenreihen klassifiziert wurden (Diers-Fenger et al. 2001; Wilson et al. 2003).

NG2-positiven Zellen differenzieren sich in Kultur zu Astrozyten und Oligodendrozyten (DiersFenger et al. 2001) und GABAergen Neuronen (Belachew et al. 2003) aus. Da jedoch im Hirnstamm keine Ko-Expression von NG2 und dem früh postmitotischen Neuronenmarker TUC-4 (Quinn et al. 1999; Quinn et al. 2003) in EGFP-positiven Zellen gefunden werden konnte, scheinen die auswärts gleichrichtenden Astrozyten nicht zu einer neuronal differenzierten Zellpopulation und damit wahrscheinlich eher zu der glialen Zelllinie zu gehören.

In Zellkulturen aus Sehnerven wurden ebenfalls NG2-positive Zellen beschrieben, die als O2AZellen bezeichnet wurden (Raff et al. 1983). GFAP-negative Zellen mit ähnlichen Eigenschaften wie auswärts gleichrichtende Astrozyten wurden als oligodendrocyte progenitor cells (OPC) beschreiben, Zellen die z.B. in demyelinisierte ZNS-Bereiche einwandern können und dort eine Remyelinisierung bewirken können (Wilson et al. 2003)

Interessanterweise traten auswärts gleichrichtende Astrozyten im Hirnstamm unabhängig vom Alter der untersuchten Tiere auf (p0-p23). Die Anzahl NG2-positiver Zellen unter den schwach fluoreszierenden Astrozyten ist im respiratorischen Netzwerk von TgN(hGFAP-EGFP) Mäusen im Alter von 2 Tagen und 23 Tagen vergleichbar. Dass diese Zellen auch in großer Zahl in Hirnen adulter Tiere auftauchen können, spricht gegen die Hypothese einer undifferenzierten Vorläuferzelle (Kimelberg 2004).

Somit besteht die Möglichkeit, dass es sich bei diesen Zellen um einen eigenständigen reifen Zelltyp handelt, dessen Funktion bisher nicht beschrieben wurde. Die Bezeichnung „Astrozyt“ 
muss somit genauer überprüft werden. Es konnte in diesen Zellen immunohistochemisch keine GFAP-Expression nachgewiesen werden. Trotzdem zeigten diese Zellen eine geringe EGFPExpression. EGFP wurde in dieser Mauslinie unter der Kontrolle eines Fragments des humanen GFAP-Promoters exprimiert (Nolte et al. 2001). Da es sich dabei nicht um den vollständigen murinen GFAP-Promoter handelt, ist eine Exklusivität der EGFP-Produktion nur in GFAPexprimierenden Zellen nicht vollkommen sicher. Dies unterstützt die Hypothese, dass auswärts gleichrichtende Astrozyten eine andere Zelllinie als passive und intermediäre Astrozyten repräsentieren könnten.

Im Hippocampus wurden frisch isolierte Zellen beschrieben, deren Eigenschaften denen der auswärts gleichrichtenden Astrozyten sehr ähnlich sind. Lediglich ein dort beschriebenes völliges Fehlen der Glutamat-Transporter unterscheidet diese Zellen von denen im respiratorischen Netzwerk (Zhou and Kimelberg 2000; Zhou and Kimelberg 2001; Matthias et al. 2003).

Diese Zellen wurden aufgrund ihrer Eigenschaften als astrons bezeichnet (Matthias et al. 2003)., was einen Status der Zellen zwischen Gliazellen und Neuronen benennen soll. Im Hirnstamm konnte in ca. $50 \%$ der auswärts gleichrichtenden Zellen spannungsabhängige $\mathrm{Na}^{+}$-Kanäle nachgewiesen werden. Jedoch konnte niemals ein Aktionspotential in diesen Zellen detektiert werden.

Die Hypothese, dass NG2-positive Gliazellen einen eigenständigen reifen Zelltyp repräsentieren, wurde in einer weiteren Reihe von Arbeiten favorisiert. Dabei werden sie u.a. als sogenannte Synantozyten bezeichnet (Butt et al. 2002). Synantozyten sind demnach komplexe Zellen, die Kontakt zu Neuronen, deren Axonen, Ranvier'schen Schnürringen und Synapsen haben, sich postnatal entwickeln und einen Einfluss auf neuronale Plastizität haben (Butt et al. 2002).

Für Synantozyten im Groß- und Kleinhirn wurden ähnliche morphologische Eigenschaften (zahlreiche Fortsätze mit kleinen knötchenartigen Strukturen) beschrieben (Butt et al. 2002), wie sie auch bei auswärts gleichrichtenden Astrozyten im respiratorischen Netzwerk beobachtet werden konnten. Ein direkter Zellkontakt mit Neuronen konnte im respiratorischen Netzwerk ebenfalls 
dargestellt werden. Synantozyten sind wie passive Astrozyten and der Bildung von Narbengewebe (Gliose) nach ZNS-Verletzungen beteiligt (Butt et al. 2002).

NG2-positive Zellen können sich zwar zum Teil zu Oligodendrozyten weiterentwickeln, während ein Großteil der NG2-positiven Gliazellen im adulten Hirn neben Oligodendrozyten, Astrozyten und Mikroglia als vierte große Gliazellpopulation bestehen bleibt (Nishiyama et al. 2002). Diese Zellgruppe wurde als Polydendrozyten beschrieben (Nishiyama et al. 2002). In einer elektronenmikroskopischen Studie wurde diese Zellpopulation untersucht und als $\beta$-Neuroglia bezeichnet (Peters 2004). Dabei wurde als ein Unterscheidungskriterium zu anderen Astroyzen das Fehlen intermediärer Filamente sowie ein fehlender direkter Kontakt zu Kapillargefäßen gewählt (Peters 2004). In auswärts gleichrichtenden Astrozyten konnte mittels Immunfärbungen keine Expression des Astrozyten-spezifischen intermediären Filaments GFAP nachgewiesen werden.

Auswärts gleichrichtende Astrozyten im respiratorischen Netzwerk exprimieren sowohl GlutamatRezeptoren vom AMPA-Typ als auch ionotrope GABA-Rezeptoren, jedoch keine GlyzinRezeptoren (Szöke et al. 2004). Im Hippocampus sind auf NG2-positiven Zellen glutamaterge und GABAerge Synapsen nachgewiesen (Jabs et al. 2004, Bergles et al. 2002, Lin und Bergles 2004). Über diese Synapsen könnten Informationen über die neuronale Exzitation detektiert werden. Diese Informationen könnten über die postulierte Migrations- und Proliferationsfähigkeit dieser Zellen (Pende et al. 1994; Knutson et al. 1997; Wang et al. 2000) eine gliale und/oder neuronale Plastizität mit steuern. Der direkte Kontakt von auswärts gleichrichtenden Astrozyten zu anderen Astrozyten, Blutgefäßen und Neuronen würde eine mögliche sensorische Funktion dieser Zellen unterstützen.

Die in den oben zitierten verschiedenen Arbeiten beschriebenen NG2-positiven Zellen gehören wahrscheinlich nicht einer einzigen Zellpopulation, sondern lassen sich in mehrere Gruppen einteilen. Die NG2-positiven Zellen einer Gruppe werden als Vorläuferzellen beschrieben. Dabei wurden sie als Vorläuferzellen für Neurone (Belachew et al. 2003) und Vorläuferzellen für Oligodendrozyten (Diers-Fenger et al. 2001, Dawson et al. 2003, Wilson et al. 2003) identifiziert. 
Eine weitere Gruppe von in verschiedenen ZNS-Gebieten mit unterschiedlichen Techniken untersuchten NG2-positiven Zellen unterstützt vermehrt die Hypothese eines eigenen reifen Zelltyps, dessen Aufgabe noch nicht näher geklärt ist. Diese Zellen werden als Synantozyten (Butt et al. 2002), astrons (Matthias et al. 2003), B-Neuroglia (Peters 2004), Polydendrozyten ((Nishiyama et al. 2002) oder outwardly rectifying astrocytes (Zhou and Kimelberg 2001, Grass et al. 2004) bezeichnet. Die auswärts gleichrichtenden Astrozyten scheinen als Mitglied dieser Gruppe am ehesten eine eigene Zellpopulation darzustellen, die sich von anderen Astrozyten abgrenzen lässt.

Welche dieser verschiedenen Hypothesen bezüglich der Funktion und der Herkunft von auswärts gleichrichtenden Astrozyten man nun betrachtet, sie sind relevant für die prä- und postnatale Entwicklung des respiratorischen Netzwerks. Dort müssen Verschaltungen, die die koordinierte Netzwerkaktivität überhaupt erst erlauben, bereits bei der Geburt funktionsfähig sein, um die Atmung und andere lebenswichtige vegetative Funktionen möglich zu machen. Eine Plastizität dieses Netzwerks ist aber auch postnatal nötig, da sich die Atmung an die sich ständig verändernden Lebensbedingungen anpassen muss.

In Kontext ist es erwähnenswert, dass im Alter von 2 Tagen postnatal keine TUC-4Immunfluoreszenz in den Kerngebieten der VRG und des N. XII nachgewiesen werden konnte. Dies spricht dafür, dass dort die Neurongenese bereits zum Zeitpunkt der Geburt abgeschlossen ist. Die Reorganisierung und Adaptation der synaptischen Architektur im respiratorischen Netzwerk ist abhängig von den funktionellen Anforderung nach der Geburt (Hilaire und Duron 1999, Richter und Spyer 2001). Vor allem in den ersten zwei postnatalen Wochen verändern sich dort viele Strukturen, so z.B. die Dichte der Glutamat-Rezeptoren und der respiratorischen Neurone (Liu und Wong-Riley 2002). Das postnatale Wachstum des Hirnstamms und das Dendritenwachstum erfordern eine permanente funktionelle Adaptation der Synapsen und der Zytoarchitektur und damit auch der Gliazellen und deren Fortsätze. 
Die Daten dieser Studie schließen eine Neu-Organisation der neuronalen Struktur mit einer Neurogenese im respiratorische Netzwerk nicht aus, jedoch favorisieren sie eine starke gliale Plastizität in diesen Bereichen des Hirnstamms.

\subsection{Funktionelle Relevanz der Expression von Glutamat- Rezeptoren und Transportern}

In dieser Studie wurde eine variable EGFP-Fluoreszenz der Astrozyten des respiratorischen Netzwerks gefunden. Eine ähnliche Variabilität wurde bei Astrozyten im Hippocampus (Matthias et al. 2003), jedoch nicht in Bergmann-Glia im Zerebellum (Nolte et al. 2001) gefunden.

Matthias et al. 2003 beschrieben eine Eins-zu-eins-Korrelation der Fluoreszenzintensität und der zellulären Parameter wie z.B. der Expression von Glutamat-Rezeptoren und niedriger Fluoreszenz und im Gegensatz dazu der Expression von Glutamat-Rezeptoren in Zellen mit heller Fluoreszenz. Es wurde sogar eine Ko-Expression von Glutamat-Rezeptoren vom AMPA-Typ und GlutamatTransportern in hippocampalen Astrozyten ausgeschlossen.

Im Gegensatz dazu konnte in der vorliegenden Arbeit im respiratorischen Netzwerks eben diese Ko-Expression von Glutamat-Rezeptoren und Transportern in Astrozyten mit starker EGFPFluoreszenz nachgewiesen werden. Der Nachweis mit Hilfe verschiedener Versuchsansätze (elektrophysiologisch, Einzelzell-RT-PCR) gelang in elektrophysiologisch sowohl als passiv als auch in als intermediär charakterisierten Astroyzten.

Eine solche Ko-Expression konnten auch in Bergmann-Gliazellen im Zerebellum gefunden werden (Clark und Barbour 1997). Bergmann-Glia zeigen ebenfalls starke hGFAP-Promoter-induzierte EGFP-Fluoreszenz (Nolte et al. 2001). Es konnte gezeigt werden, dass in Bergmann-Gliazellen $\mathrm{Ca}^{2+}$-permeable AMPA-Typ-Glutamat-Rezeptoren die Umhüllung von Synapsen durch gliale Fortsätze regulieren. (Iino et al. 2001). Im Hirnstamm zeigen Astrozytenfortsätze ein hohes Maß an spontaner Motilität, kontaktieren so neuronale Zellkörper und umhüllen aktive Synapsen (Hirrlinger et al. 2004) 
Im respiratorischen Netzwerk konnten passive und intermediäre Astrozyten identifiziert werden, die wie Bergmann-Gliazellen sowohl Eigenschaften besaßen, die die synaptische Transmission stabilisieren können (Möglichkeiten zur $\mathrm{K}^{+}$-Pufferung und zur Glutamataufnahme), als auch AMPA-Rezeptoren exprimierten, die potentiell die synaptische Plastizität regulieren könnten.

Außerdem wurden in andern Arbeiten weitere Aspekte der Bedeutung der Expression von AMPATyp-Glutamat-Rezeptoren diskutiert. Dabei wurde ein Einfluss auf die Expression von Transportern, $\mathrm{K}^{+}$-Leitfähigkeiten sowie auf die Kopplung mittels Gap-Junctions postuliert (Muller et al. 1992; Gegelashvili et al. 1996; Muller et al. 1996).

Astrozyten, die eine Ko-Expression von ionotropen Glutamat-Rezeptoren und GlutamatTransportern aufweisen, könnten also einen wesentlichen Einfluss auf die Plastizität des respiratorischen Netzwerks ausüben. 


\section{Zusammenfassung}

Im respiratorischen Netzwerk in der kaudalen Medulla oblongata generiert eine Gruppe von Neuronen eine rhythmische Aktivität, die die Atembewegungen steuert. Die synaptische Transmission sowie das neuronale Zusammenspiel in diesem Netzwerk ist mittlerweile gut erforscht, die Rolle der Gliazellen in diesem Netzwerk ist jedoch weitestgehend unklar.

In der ventralen respiratorischen Gruppe (VRG) und im Kerngebiet des N. hypoglossus (Ncl. $\mathrm{n}$. XII) in frisch isolierten Hirnstammschnitten aus TgN(hGFAP-EGFP)-Mäusen wurden fluoreszierende Astrozyten mit der Whole-cell-Voltage-clamp-Technik analysiert. Anhand unterschiedlicher Membranströme konnten drei Subpopulationen unterschieden werden. Eine Gruppe zeigte symmetrische, nicht gleichrichtende Membranströme und einen deutlichen Einwärtsstrom nach Applikation des Glutamat-Transporter-Agonisten D-Aspartat. Eine zweite Gruppe ähnelte diesen Zellen, wies jedoch einen zusätzlichen auswärts gerichteten spannungsgesteuerten A-Typ- $\mathrm{K}^{+}$-Strom auf. Eine dritte Gruppe, immunhistochemisch markierbar mit Antikörpern gegen den glialen Vorläuferzell-Marker NG2, wurde durch auswärts gleichrichtende $\mathrm{K}^{+}$-Ströme, deutlich geringere Einwärtsströme und geringe D-Aspartat-induzierte Transporter-Ströme charakterisiert. Astrozyten aller drei Gruppen zeigten durch Kainat induzierte ionotrope Glutamat-Rezeptorströme. Astrozyten der ersten und zweiten Gruppe zeigten sich als reife Astrozyten, die im respiratorischen Netzwerk ein über Gap-junctions gekoppeltes Synzytium bilden. Dies ist in der Lage, die extrazelluläre $\mathrm{K}^{+}$- und Glutamatkonzentration zu regulieren und damit die neuronale Netzwerkaktivität zu stabilisieren. Die dritte Gruppe von Astrozyten zeigt dagegen charakteristische Merkmale für frühe Differenzierungsstufen von glialen und neuronalen Zellen. Diese Zellen konnten allerdings in verschiedenen Hirnregionen und auch in adulten Tieren beobachtet werden. Aufgrund ihres Kontaktes zu Astrozyten, Neuronen, Blutgefäßen sowie der Ausbildung von glutamatergen synapsenähnlichen Strukturen könnten diese Zellen in der Lage sein, neuronale Aktivität zu messen und einen Anteil an der prä- und postnatalen Plastizität des respiratorischen Netzwerks zu haben. 


\section{Ergebnisse dieser Doktorarbeit wurden in folgender Originalarbeit} veröffentlicht:

Grass D, Pawlowski PG, Hirrlinger J, Papadopoulos N, Richter DW, Kirchhoff F, Hulsmann S (2004): Diversity of Functional Astroglial Properties in the Respiratory Network. J Neurosci 24(6), $1358-1365$

\section{Teilergebnisse dieser Doktorarbeit wurden als Kongressbeiträge publiziert:}

Grass, Kirchhoff F, Richter DW, Hulsmann S (2002): Function of astrocytes in respiratory network in mouse brain stem slice. Pflugers Arch 443 Supplement 1, P10-8, Nominiert für den Poster-Preis

Grass D, Quintela-Schneider M, Kirchhoff F, Richter DW, Hulsmann S (2004): Characterization of astrocytes in the respiratory network. $3^{\text {rd }}$ Forum of European Neuroscience, Paris; Poster 182.12

Grass, Hirrlinger J, Pawlowski PG, Latal T, Kirchhoff F, Hulsmann S (2004): Specialized astroglial cells with neuronal and glial properties in the respiratoty network. Pflugers Arch $\underline{447}$ Supplement 1, O25-1 


\section{Abkürzungsverzeichnung}

$\begin{array}{ll}\text { 2p-LSM } & \text { 2-Photonen-Laserscanning-Mikroskop } \\ \text { aCSF } & \text { artifizielle zerebrospinale Flüssigkeit } \\ \text { AD/DA Wandler } & \text { analog/digital-/digital/analog Wandler } \\ \text { AMPA } & \alpha \text {-Amino-3-hydroxy-5-methyl-4-isoxazol-Propionsäure } \\ \text { ANOVA } & \text { Varianzanalyse (analysis of variance) } \\ \text { CCD-Kamera } & \text { charge-coupled-device-Kamera } \\ \text { cDNA } & \text { copy-Desoxyribonukleinsäure } \\ \text { cLSM } & \text { konfokales Laserscanning-Mikroskop } \\ \text { dNTP } & \text { Desoxynukleosidtriphosphat } \\ \text { DRG } & \text { Dorsale respiratorische Gruppe } \\ \text { EAAT } & \text { excitatoric amino acid transporter } \\ \text { EGFP } & \text { enhanced green fluorescent proteine } \\ \text { FCS } & \text { Fetales Kälber-Serum } \\ \text { GFAP } & \text { glial fibrillary acidic protein } \\ \text { GLAST } & \text { glutamate-aspartate-transporter } \\ \text { GLT-1 } & \text { glutamate-transporter-1 } \\ \text { hGFAP-Promoter } & \text { humaner GFAP-Promotor } \\ \text { I/V-Kurve } & \text { Strom-Spannungs-Kurve } \\ \text { mRNA } & \text { messenger-Ribonukleinsäure } \\ \text { N. XII } & \text { Nervus hypoglossus } \\ \text { Ncl. } & \text { Nucleus } \\ \text { NK-1 } & \text { Neurokinin-1 } \\ \text { PBC } & \text { Prä-Bötzinger Komplex } \\ \text { PBS } & \text { phosphate-buffered saline } \\ \text { PFA } & \text { Paraformaldehyd } \\ \text { rt-PCR } & \text { Reverse-Transkriptase-Polymerase-Ketten-Reaktion } \\ \text { TgN(hGFAP-EGFP) } & \text { (Bezeichnung für die benutzte transgene Mauslinie) } \\ \text { VRG } & \text { Ventrale respiratorische Gruppe } \\ \text { ZNS } & \text { Zentrales Nervensystem }\end{array}$




\section{Literaturverzeichnis}

Belachew S, Chittajallu R, Aguirre AA, Yuan X, Kirby M, Anderson S, Gallo V (2003): Postnatal NG2 proteoglycan-expressing progenitor cells are intrinsically multipotent and generate functional neurons. J Cell Biol 161(1), 169-186

Bergles DE, Tzingounis AV, Jahr CE (2002): Comparison of coupled and uncoupled currents during glutamate uptake by GLT-1 transporters. J Neurosci 22(23), 10153-62, Erratum in: J Neurosci 23(2), 726

Bianchi AL, Denavit-Saubie M \& Champagnat J (1995): Central control of breathing in mammals: neuronal circuitry, membrane properties, and neurotransmitters. Physiol Rev $\underline{75}, 1-45$

Bordey A, Sontheimer H (1999): Differential inhibition of glial K(+) currents by 4-AP. J Neurophysiol $\underline{82(6)}, 3476-87$

Bordey A, Sontheimer H (2000): Ion channel expression by astrocytes in situ: comparison of different CNS regions. Glia $\underline{30(1)}, 27-38$

Brockhaus J, Ballanyi K, Smith JC, Richter DW (1993): Microenvironment of respiratory neurons in the in vitro brainstem-spinal cord of neonatal rats. J Physiol $\underline{462}, 421-45$

Butt AM, Kiff J, Hubbard P, Berry M (2002): Synantocytes: new functions for novel NG2 expressing glia. J Neurocytol 31(6-7), 551-65 Review

Clark BA, Barbour B (1997): Currents evoked in Bergmann glial cells by parallel fibre stimulation in rat cerebellar slices. J Physiol 502( Pt 2), 335-50 
Dawson MR, Polito A, Levine JM, Reynolds R (2003): NG2-expressing glial progenitor cells: an abundant and widespread population of cycling cells in the adult rat CNS. Mol Cell Neurosci $\underline{24}$, $476-488$

Diers-Fenger M, Kirchhoff F, Kettenmann H, Levine JM, Trotter J (2001): AN2/NG2 proteinexpressing glial progenitor cells in the murine CNS: isolation, differentiation, and association with radial glia. Glia $\underline{34(3)}, 213-28$

Dong XW, Feldman JL (1999): Distinct subtypes of metabotropic glutamate receptors mediate differential actions on excitability of spinal respiratory motoneurons. J Neurosci 19(13), 5173-84

Edwards GL, Cunningham JT, Beltz TG, Johnson AK (1989): Neuropeptide Y-immunoreactive cells in the caudal medulla project to the median preoptic nucleus. Neurosci Lett 105(1-2), 19-26

Filippov V, Kronenberg G, Pivneva T, Reuter K, Steiner B, Wang LP, Yamaguchi M, Kettenmann H, Kempermann G (2003): Subpopulation of nestin-expressing progenitor cells in the adult murine hippocampus shows electrophysiological and morphological characteristics of astrocytes. Mol Cell Neurosci 23(3), 373-82

Funk GD, Smith JC, Feldman JL (1993): Generation and transmission of respiratory oscillations in medullary slices: role of excitatory amino acids. J Neurophysiol $\underline{70(4)}, 1497-515$

Gegelashvili G, Civenni G, Racagni G, Danbolt NC, Schousboe I, Schousboe A (1996): Glutamate receptor agonists up-regulate glutamate transporter GLAST in astrocytes. Neuroreport $\underline{8(1)}, 261-5$ 
Gomeza J, Hulsmann S, Ohno K, Eulenburg V, Szoke K, Richter D, Betz H (2003): Inactivation of the glycine transporter 1 gene discloses vital role of glial glycine uptake in glycinergic inhibition. Neuron 40(4), 785-96. Erratum in: Neuron 41(4), 675

Grass D, Pawlowski PG, Hirrlinger J, Papadopoulos N, Richter DW, Kirchhoff F, Hulsmann S (2004): Diversity of Functional Astroglial Properties in the Respiratory Network. J Neurosci 24(6), $1358-1365$

Greer JJ, Smith JC, Feldman JL (1992): Glutamate release and presynaptic action of AP4 during inspiratory drive to phrenic motoneurons. Brain Res 576(2), 355-7

Guyenet PG, Wang H (2001): Pre-Botzinger neurons with preinspiratory discharges "in vivo" express NK1 receptors in the rat. J Neurophysiol $\underline{86(1)}, 438-46$

Hilaire G, Duron B (1999): Maturation of the mammalian respiratory system. Physiol Rev $\underline{79(2)}$, 325-60 Review

Hirrlinger J, Hulsmann S, Kirchhoff F (2004): Astroglial processes show spontaneous motility at active synaptic terminals in situ. Eur J Neurosci 20(8), 2235-9

Hulsmann S, Oku Y, Zhang W, Richter DW (2000 a): Metabotropic glutamate receptors and blockade of glial Krebs cycle depress glycinergic synaptic currents of mouse hypoglossal motoneurons. Eur J Neurosci 12(1), 239-46 
Hulsmann S, Oku Y, Zhang W, Richter DW (2000 b): Metabolic coupling between glia and neurons is necessary for maintaining respiratory activity in transverse medullary slices of neonatal mouse. Eur J Neurosci 12(3), 856-62

Iino M, Goto K, Kakegawa W, Okado H, Sudo M, Ishiuchi S, Miwa A, Takayasu Y, Saito I, Tsuzuki K, Ozawa S (2001): Glia-synapse interaction through Ca2+-permeable AMPA receptors in Bergmann glia. Science 292(5518), 926-9

Jabs R, Kirchhoff F, Kettenmann H, Steinhauser C (1994): Kainate activates Ca(2+)-permeable glutamate receptors and blocks voltage-gated $\mathrm{K}+$ currents in glial cells of mouse hippocampal slices. Pflugers Arch 426(3-4), 310-9

Jabs R, Wallraff A, Büssow H, Steinhäuser C (2004): Postsynaptic currents in hGFAP/EGFP labeled hippocampal glial cells. Pflugers Arch 447 Supplement 1, 31-11

Kimelberg HK (2004): The problem of astrocyte identity. Neurochem Int 45(2-3), 191-202 Review

Knutson P, Ghiani CA, Zhou JM, Gallo V, McBain CJ (1997): K+ channel expression and cell proliferation are regulated by intracellular sodium and membrane depolarization in oligodendrocyte progenitor cells. J Neurosci 17(8), 2669-82

Kofuji P, Newman EA (2004): Potassium buffering in the central nervous system. Neuroscience 129(4), 1045-56 Review

Koshiya N, Smith JC (1999): Neuronal pacemaker for breathing visualized in vitro. Nature $\underline{400(6742)}, 360-3$ 
Kullmann DM, Asztely F (1998): Extrasynaptic glutamate spillover in the hippocampus: evidence and implications. Trends Neurosci 21(1), 8-14 Review

Lin SC, Bergles DE (2004): Synaptic signaling between GABAergic interneurons and oligodendrocyte precursor cells in the hippocampus. Nat Neurosci 7(1), 24-32

Liu Q, Wong-Riley MT (2002): Postnatal expression of neurotransmitters, receptors, and cytochrome oxidase in the rat pre-Botzinger complex. J Appl Physiol 92(3), 923-34

Matthias K, Kirchhoff F, Seifert G, Huttmann K, Matyash M, Kettenmann H, Steinhauser C (2003): Segregated expression of AMPA-type glutamate receptors and glutamate transporters defines distinct astrocyte populations in the mouse hippocampus. J Neurosci $\underline{23(5)}, 1750-8$

McKhann GM 2nd, D'Ambrosio R, Janigro D (1997): Heterogeneity of astrocyte resting membrane potentials and intercellular coupling revealed by whole-cell and gramicidin-perforated patch recordings from cultured neocortical and hippocampal slice astrocytes. J Neurosci 17(18), 6850-63

Mennerick S, Shen W, Xu W, Benz A, Tanaka K, Shimamoto K, Isenberg KE, Krause JE, Zorumski CF (1999): Substrate turnover by transporters curtails synaptic glutamate transients. J Neurosci 19(21), 9242-51

Muller T, Moller T, Berger T, Schnitzer J, Kettenmann H (1992): Calcium entry through kainate receptors and resulting potassium-channel blockade in Bergmann glial cells. Science 256(5063), 1563-6. Erratum in: Science 257(5074), 1190 
Muller T, Fritschy JM, Grosche J, Pratt GD, Mohler H, Kettenmann H (1994): Developmental regulation of voltage-gated $\mathrm{K}+$ channel and GABAA receptor expression in Bergmann glial cells. $\mathrm{J}$ Neurosci. 14(5 Pt 1), 2503-14

Muller T, Moller T, Neuhaus J, Kettenmann H (1996): Electrical coupling among Bergmann glial cells and its modulation by glutamate receptor activation. Glia 17(4), 274-84

Nishiyama A, Watanabe M, Yang Z, Bu J (2002): Identity, distribution, and development of polydendrocytes: NG2-expressing glial cells. J Neurocytol 31(6-7), 437-55 Review

Nolte C, Matyash M, Pivneva T, Schipke CG, Ohlemeyer C, Hanisch UK, Kirchhoff F, Kettenmann H (2001): GFAP promoter-controlled EGFP-expressing transgenic mice: a tool to visualize astrocytes and astrogliosis in living brain tissue. Glia $\underline{33(1)}, 72-86$

Pende M, Holtzclaw LA, Curtis JL, Russell JT, Gallo V (1994): Glutamate regulates intracellular calcium and gene expression in oligodendrocyte progenitors through the activation of DL-alphaamino-3-hydroxy-5-methyl-4-isoxazolepropionic acid receptors. Proc Natl Acad Sci USA 91(8), $3215-9$

Peters A.(2004): A fourth type of neuroglial cell in the adult central nervous system. J Neurocytol $\underline{33(3)}, 345-57$

Quinn CC, Gray GE, Hockfield S (1999): A family of proteins implicated in axon guidance and outgrowth. J Neurobiol 41(1), 158-64 Review 
Quinn CC, Chen E, Kinjo TG, Kelly G, Bell AW, Elliott RC, McPherson PS, Hockfield S (2003): TUC-4b, a novel TUC family variant, regulates neurite outgrowth and associates with vesicles in the growth cone. J Neurosci 23(7), 2815-23

Raff MC, Miller RH, Noble M (1983): A glial progenitor cell that develops in vitro into an astrocyte or an oligodendrocyte depending on culture medium. Nature 303(5916), 390-6

Richter DW, Spyer KM (2001): Studying rhythmogenesis of breathing: comparison of in vivo and in vitro models. Trends Neurosci 24(8), 464-72 Review

Richter DW, Camerer H, Sonnhof U (1978): Changes in extracellular potassium during the spontaneous activity of medullary respiratory neurones. Pflugers Arch $\underline{376(2)}, 139-49$

Robinson D, Ellenberger H (1997): Distribution of N-methyl-D-aspartate and non-N-methyl-Daspartate glutamate receptor subunits on respiratory motor and premotor neurons in the rat. J Comp Neurol $\underline{389(1)}, 94-116$

Rusakov DA, Kullmann DM (1998): A tortuous and viscous route to understanding diffusion in the brain. Trends Neurosci 21(11), 469-70

Rybak IA, Shevtsova NA, St-John WM, Paton JF, Pierrefiche O (2003): Endogenous rhythm generation in the pre-Botzinger complex and ionic currents: modelling and in vitro studies. Eur J Neurosci 18(2), 239-57

Schmidt RF, Lang F, Thews G: Physiologie des Menschen. 29. Auflage; Springer Verlag, Berlin 2005 
Smith JC, Ellenberger HH, Ballanyi K, Richter DW, Feldman JL (1991): Pre-Botzinger complex: a brainstem region that may generate respiratory rhythm in mammals. Science 254(5032), 726-9

Szöke K, Hulsmann S, Kirchhoff F (2004): Function of astrocytes in the inhibitory synaptic transmission in the respiratory network. Pflugers Arch 447 Supplement 1, 04-3

Wang JY, Wang J, Golovina VA, Li L, Platoshyn O, Yuan JX (2000): Role of K(+) channel expression in polyamine-dependent intestinal epithelial cell migration. Am J Physiol Cell Physiol 278(2), 303-14

Wilson HC, Onischke C, Raine CS (2003): Human oligodendrocyte precursor cells in vitro: phenotypic analysis and differential response to growth factors. Glia $\underline{44(2)}, 153-65$

Zhou M, Kimelberg HK (2000): Freshly isolated astrocytes from rat hippocampus show two distinct current patterns and different $[\mathrm{K}(+)](\mathrm{o})$ uptake capabilities. J Neurophysiol $\underline{84(6)}, 2746-57$

Zhou M, Kimelberg HK (2001): Freshly isolated hippocampal CA1 astrocytes comprise two populations differing in glutamate transporter and AMPA receptor expression. J Neurosci 2001 $\underline{21(20)}, 7901-8$ 


\section{Danksagung}

Ich möchte mich an erster Stelle bei meinem Betreuer und Doktorvater Privatdozent Dr. med. Swen Hülsmann bedanken, der über die Zeit dieser Promotionsarbeit immer hinter mir gestanden ist. Während dieses Weges hatte er trotz allem Stress immer genug Zeit übrig, um mir bei der Lösung aller möglichen Probleme zu helfen. Und letztendlich ist dann alles sehr gut gelaufen. Vielen Dank für alles!

Desweiteren möchte ich mich bei Herrn Prof. Dr. med. Diethelm W. Richter bedanken, der mir diese Arbeit durch Bereitstellung von Geräten und Räumlichkeiten und nicht zuletzt durch die kritische und hilfreiche Durchsicht von Poster- und Papermanuskripten ermöglicht hat.

Auch bei Herrn Privatdozent Dr. rer. nat. Frank Kirchhoff möchte ich mich herzlich bedanken, nicht nur für die Bereitstellung der „grünen Mäuse“ für meine Experimente, sondern auch für die vielen Diskussionen, welches die Qualität dieser Arbeit maßgeblich verbessert haben.

Auch bei Petra Hirrlinger, Dr. rer. nat. Johannes Hirrlinger und Nestoras Papadopoulos möchte ich mich nicht nur für die Zusammenarbeit bedanken, sondern auch für die schöne Zeit, die wir miteinander hatten. Danke auch an Dr. med. Markus Quintela-Schneider, der mich in die Geheimnisse der Immunfärbung eingeführt hat.

Meinen Mitstreiterinnen und Mitstreitern, medizinischen wie naturwissenschaftlichen Doktorandinnen und Doktoranden, als da wären Sabine, Katalin, Anja, Eugenia, Marco, Thorsten, Christian und Tobias, wünsche ich ein gutes Gelingen und eine weitere schöne Zeit in der AG Hülsmann!

Für die technische und moralische Unterstützung bedanke ich mich noch einmal herzlich bei AnjaAnett Grützner.

Dennis Graß, Göttingen, September 2005 


\section{Lebenslauf}

von Dennis Graß

Ich wurde am 14.07. 1978 in Paderborn geboren. 1985 wurde ich in der Katholischen Grundschule Egge in Altenbeken eingeschult. Ab 1989 besuchte ich dann das Gymnasium St. Xaver in Bad Driburg. Dort legte ich im Mai 1998 erfolgreich meine Abiturprüfungen ab und erlangte so die Hochschulreife.

Anschließend leistete ich ab dem Sommer 1998 den 13-monatigen Zivildienst in der Jugendherberge Bad Driburg ab. Zum Wintersemester 1999/2000 trat ich mein Studium der Humanmedizin an der Georg-August-Universität Göttingen an. Dort absolvierte ich im August/September 2001 erfolgreich die ärztliche Vorprüfung.

Ab Oktober 2001 führte ich ein sechsmonatiges Praktikum in der Abteilung Neuro- und Sinnesphysiologie durch, um die experimentellen Grundlagen für meine Dissertation zu erlernen. Im März 2003 bestand ich dann den 1. Abschnitt der ärztlichen Prüfung.

Im Laufe meines Studiums famulierte ich in den Fächern Neuroradiologie (Uniklinikum Göttingen), Neurochirurgie (Uniklinikum Rostock), Unfallchirurgie (Uniklinikum Göttingen) und neurologische Intensivmedizin (Uniklinikum Göttingen). Zudem leistete ich ein freiwilliges Praktikum in der Abteilung Neurochirurgie der Universität Göttingen ab. Im März 2005 legte ich erfolgreich den 2. Abschnitt der ärztlichen Prüfung ab.

Im April 2005 begann ich das Praktische Jahr am Uniklinikum Göttingen (Wahlfach Neurochirurgie). Voraussichtlich werde ich im Frühjahr 2006 den 3. Abschnitt der ärztlichen Prüfung absolvieren. 